\title{
Fundamentos de una nueva política forestal para el Perú
}

\author{
Fundaments of a new Peruvian forest policy
}

\author{
Marc J. Dourojeanni ${ }^{1, \star}$, Jorge Malleux ${ }^{1}$, César Sabogal ${ }^{2}$, Ignacio Lombardi ${ }^{3}$, \\ Roger Tarazona ${ }^{4}$, Carlos Rincón ${ }^{2}$, Helmut Scheuch $^{2}$ y César A. Barriga ${ }^{5}$
}

Recibido: 28 setiembre 2021 |Aceptado: 02 diciembre 2021 | Publicado en línea: 29 diciembre 2021 Citación: Dourojeanni, MJ; Malleux, J; Sabogal, C; Lombardi, I; Tarazona, R; Rincón, C; Scheuch, H; Barriga, CA. 2021. Fundamentos de una nueva política forestal para el Perú. Revista Forestal del Perú 36(2): 118-179. DOI: http://dx.doi.org/10.21704/rfp.v36i2.1796

\begin{abstract}
Resumen
Se presentan los fundamentos de una nueva política para los bosques del Perú como respuesta a su situación, marcada por la deforestación y la degradación, su insignificante aporte al PBI y su incapacidad de abastecer la demanda nacional, a pesar de que los bosques cubren la mayor parte del territorio nacional. Varias políticas, estrategias y planes, así como cinco leyes no resolvieron la situación. Por eso, se propone una reforma radical del sector, incluyendo un enfoque integral y transectorial, como única forma de abordar la deforestación, indicando responsabilidades específicas de los sectores agrario y de transporte; una nueva definición de patrimonio forestal nacional excluyendo del mismo las llamadas tierras de aptitud forestal y, por ende, descartando el anacrónico concepto de clasificación de tierras por capacidad de uso mayor. Las tierras con bosques naturales no podrán sufrir cambio de uso. En cambio, se propone que el sector agrario titule los campesinos asentados en las tierras de aptitud forestal ya deforestadas y que se acelere el proceso en curso de reconocimiento y titulación de comunidades nativas y campesinas. Además, se propone que ese sector lidere un proceso de intensificación del uso de la tierra ya deforestada mediante el aumento de la productividad agropecuaria. Se determina que la función primordial del patrimonio forestal nacional es la provisión de servicios ambientales y no, como hasta el presente, la producción de

\footnotetext{
${ }^{1}$ Facultad de Ciencias Forestales, Universidad Nacional Agraria La Molina (UNALM), Av. La Molina s/n, La Molina, Lima, Perú.

${ }^{2}$ Consultor independiente.

${ }^{3}$ Cámara Nacional Forestal (CNF), Lima, Perú.

${ }^{4}$ Arucyami S.A.C.

${ }^{5}$ Pebani S.A.

*Autor de Correspondencia: marc.dourojeanni@gmail.com
} 
madera. Por tanto, se devuelve al Estado la responsabilidad del manejo forestal, ahora encargada a los que aprovechan el recurso forestal. Para asegurar el abastecimiento de madera se estimularán las plantaciones forestales y se propone una serie de medidas políticas y económicas para que éstas, además de suplir la demanda de madera, se conviertan en el motor de la economía y asimismo, contribuyan a aliviar los graves problemas de degradación ambiental. Entre otras medidas se proponen cambios en el tratamiento de la fauna silvestre. Se fortifica el apoyo técnico y financiero a los pobladores rurales y a las comunidades nativas y campesinas, para darles mejores oportunidades de aprovechar sosteniblemente los recursos forestales, en parte gracias a la renta generada por los servicios ecosistémicos que proveen. Eso presupone mudanzas importantes en la administración del patrimonio nacional forestal proponiéndose la creación de un Ministerio de los Recursos Naturales Renovables pero el mantenimiento de la silvicultura en el sector agrario, la promulgación de una nueva ley forestal y de leyes especiales para atender la silvicultura, la fauna silvestre, la titulación de tierras, entre otras. Se trata asimismo de temas de educación, investigación y, finalmente, el de la corrupción en el sector forestal.

Palabras clave: bosques, ecosistemas naturales, deforestación, degradación forestal, manejo forestal, sostenibilidad, política, legislación, instituciones

\begin{abstract}
The fundaments of a new policy for the Peruvian forests are presented as a response to its situation, marked by deforestation and degradation, its insignificant contribution to the national GDP and its inability to supply even the national demand, despite forest resources cover most of the national territory. Several policies, strategies and plans as well as five laws did not solve the situation. Therefore, a radical reform of the sector is proposed, including a comprehensive, and cross-sectoral approach, as the only way to tackle deforestation, indicating specific responsibilities for the agricultural and transport sectors; a new definition of national forest heritage, excluding the so-called "forest aptitude land" and, therefore, discarding the anachronistic concept of land classification by its soils use capacity. Lands covered by natural forests will not be submitted to land use changes. Instead, it is proposed that the agrarian sector title the peasants settled on already deforested lands and that the ongoing process of recognition and titling of native and peasant communities be accelerated. And, in addition, it is required to lead the intensification of the use of already deforested land by increasing agricultural productivity. It is determined that the primary function of the national forest heritage is the provision of environmental services. Therefore, the responsibility for forest management currently entrusted to those who exploit forest resources must be returned to the State. To ensure the supply of timber, forest plantations will be promoted, and a series of political and economic measures are proposed so that planted forests, in addition to supplying the demand for wood, become an engine of the economy and contribute to alleviate the already serious environmental degradation. Among other measures, changes in the administration of wildlife are proposed. Technical and financial support to indigenous people and farmer communities mut be strengthened, to give them better opportunities to make sustained use of forest resources, in part thanks to the income generated by the ecosystem services they provide. This presupposes important changes in the attitude of several public sectors, such as agriculture and transportation and especially, in the administration of the national forest endowment, proposing the creation of a ministry of renewable natural resources but maintaining forest plantations within the agrarian sector, the passing of a new forest law and special laws to attend forest plantations and landscape restoration, wildlife, and land titling. Proposals are also made regarding forestry education, research and, finally, options to deal with corruption in the sector.
\end{abstract}

Key words: forests, natural ecosystems, deforestation, forest degradation, forest management, sustainability, policy, legislation, institutions 


\section{Introducción}

El creciente deterioro de los bosques y de otros ecosistemas naturales es uno de los problemas nacionales más conocidos. Preocupa a la academia, a gran parte de la sociedad y a los gobiernos, que lo discuten y toman medidas para atenderlo. Sin embargo, hasta el presente los esfuerzos han sido ineficaces y la situación del patrimonio forestal nacional es cada día más delicada, encaminándose al punto de no retorno a partir del cual pueden esperarse gravísimas consecuencias ambientales, estimuladas por el ya evidente proceso de cambio climático. La ciudadanía está cada día más expuesta a esos impactos sin siquiera recibir los beneficios económicos que se podrían espectar a partir del uso de un recurso tan importante.

Las causas de la destrucción de los bosques y de otros ecosistemas naturales continentales son antiguas, profundas y muy complejas. Combinan comportamientos sociales marcados por inequidades que provocan y mantienen la pobreza que en mucho es excusa para la desobediencia de la ley y, de otra parte, son agravadas por la incapacidad del Estado para aplicar seria y consistentemente las medidas que podrían resolver o atenuar esta situación. Dicho de otro modo, los bosques del Perú son el dominio de la informalidad y de sus males asociados, entre ellos la corrupción sistémica. Las expresiones más visibles y graves de esa realidad son, de una parte, la deforestación que se debe esencialmente a la expansión desordena$\mathrm{da}$, informal o ilegal, de la actividad agropecuaria y, de otra parte, la degradación forestal, que se debe al aprovechamiento insustentable del bosque. Las propuestas de los gobiernos y de la asistencia internacional raramente tienen éxito y si lo tienen, estos no suelen ser sostenidos ni replicados. Las nuevas propuestas, sean estas en forma de políticas, legislaciones o planes y proyectos, suelen no escapar a los parámetros anteriores y, por eso, también fracasan.

Sin embargo, como se pretende demostrar, existen respuestas y alternativas a la situación planteada. Estas implican entender bien la realidad y aceptar un cambio radical de las políticas nacionales, en especial las de los sec- tores agrario y forestal. Es por las razones mencionadas que la propuesta que se presenta no obedece a los parámetros y métodos que el Estado o el gobierno imponen a sus ejercicios de políticas, estrategias y planes. Apenas propone lo que parece ser necesario para que los bosques y otros ecosistemas naturales reciban el tratamiento que permitirá que sirvan mejor y por largo tiempo a la sociedad. Por eso: (i) difiere, a veces drásticamente, de lo que disponen las leyes vigentes; (ii) no se encuadra en las normas establecidas por el Centro Nacional de Planeamiento Estratégico (CEPLAN), o por cualquier ministerio en cuanto a preparación de políticas, planes y estrategias; (iii) aunque se basa en las opiniones de todos, no es resultado de extensas y costosas consultas públicas y; (iv) aunque sus bases y referencias son sólidas, muchas veces no son las usadas en las versiones oficiales. Es decir que este ejercicio se ha construido sin ataduras. Aun así, como es obvio, muchas de las propuestas no son nuevas e, inclusive, varias ya están en cierto modo consignadas en la legislación y políticas vigentes. Pero, de una parte, no se cumplen y, de otra, no construyen el contexto en que podrían tener éxito.

La necesidad de cambios profundos en la política forestal nacional tanto como en la política agraria con relación al bosque no es un reclamo nuevo (Moore 1992, BM 2006, Pautrat y Lucich 2006, Sabogal et al. 2008, Defensoría del Pueblo 2010, Pautrat et al. 2010, Salo et al. 2011, Suárez 2012, Dourojeanni 2013a), pero ha sido recientemente reiterada, desde diversas perspectivas (Guariguata et al. 2017; Arce 2018; Che Piu 2019; Global Witness 2019; Dourojeanni 2019b, 2020; Pautrat 2020, Ramírez y Ramos 2021) e, inclusive, ha generado algunos proyectos de ley que abordan aspectos importantes de la misma (Proyecto de Ley 2550/2017, Proyecto de Ley 07501/2021). Pero la respuesta oficial ha sido muy tímida y, salvo excepciones donde fue muy específica o parcial. Simplemente, ha insistido en repetir lo que no ha funcionado.

El objetivo de este trabajo es, pues, presentar las ideas rectoras de un nuevo enfoque del 
desarrollo foresta nacional, construido sobre bases más amplias y menos convencionales. Se trata, en realidad, de propuestas para alterar la realidad que afecta negativamente a los bosques del Perú desde hace muchas décadas. La metodología usada para preparar este documento incluye discusiones entre profesionales forestales y de temas asociados que se realizaron a lo largo de 2019 y que, a partir de mediados de 2020 fueron agrupadas temáticamente. Las conclusiones consensuadas fueron organizadas y redactadas por el equipo de autores de este artículo y sometidas a diversos segmentos de la opinión especializada en temas de política forestal, agraria y ambiental en ocho eventos virtuales formales y mediante varias conferencias brindadas en medios académicos y gremiales (Cámara Nacional Forestal 2021). Los resultados de esos eventos fueron incorporados en la medida en que se justificaban y están incluidos en el texto de este artículo en que se sustentan los fundamentos de la nueva propuesta para la gestión de los bosques del Perú.

\section{Los problemas}

La difícil situación de los bosques y ecosistemas naturales peruanos se debe principalmente a la presión por cambio de uso de la tierra y al descontrol de su utilización. Sin embargo, es evidente que la causa de fondo del mal uso de los bosques es la dominancia de un modelo de desarrollo antropocéntrico y cortoplacista. Sus expresiones más evidentes son la deforestación y la degradación del bosque. Las consecuencias incluyen, entre otros, riesgos y costos ambientales crecientes, un bajísimo aporte relativo del sector forestal a la economía nacional, escasez de productos forestales que deben ser importados y frustración de un amplio segmento de la sociedad que podría beneficiarse de los bienes y servicios resultantes de una buena gestión del bosque. De otra parte, el Estado nunca ha conseguido poner orden en el aprovechamiento de los bosques y otros ecosistemas naturales.

En esta sección se hace un breve diagnóstico de los principales problemas que se pretende resolver con la nueva propuesta de política para la gestión de los bosques y otros ecosistemas naturales continentales del país.

\section{Reducción de servicios ecosistémicos y pér- dida de diversidad biológica}

Los servicios ecosistémicos o ambientales del patrimonio forestal nacional son críticamente importantes para el país y el mundo. Muchos de los sectores más importantes de la economía peruana dependen directamente de la integridad de los ecosistemas naturales. Pero estos servicios están siendo gravemente amenazados y disminuidos por actividades económicas mal-conducidas, en especial por la deforestación con fines agropecuarios y mineros y por la degradación de los ecosistemas forestales y de la tierra en general, pero, asimismo, por la contaminación producida por la minería, la agricultura la industria y las zonas urbanas.

A nivel mundial las consecuencias de la diminución de los servicios ambientales ya son evidentes y se manifiestan con el incremento global y local de las temperaturas medias, deshielo de nevados, avance de la desertificación, sequías, inundaciones, tornados, avalanchas y derrumbes entre otros desastres "naturales", enormes incendios forestales en todos los continentes, reducción de la disponibilidad de agua y pérdida de calidad de esta, reducción de la diversidad biológica y extinciones, elevación del nivel del mar, entre otros. Todas esas consecuencias elevan los riesgos para la sociedad, aumentan la pérdida de vidas humanas e imponen altos costos para la producción de bienes.

En el Perú ya sobran las evidencias científicas y las mediciones de la acelerada reducción de los servicios ambientales, principalmente ecosistémicos, que brindan los bosques y los ecosistemas naturales (BM 2007). Estos se expresan en términos de aumento en la concentración de gases de efecto invernadero y en la reducción del volumen de carbono fijado en la biomasa y en los suelos (MINAM 2010, 2016c); en las siempre más drásticas irregularidades de los flujos hídricos en las tres regiones naturales, incluyendo las inundaciones seguidas de 
sequías violentas en la Amazonia (Marengo et al. 2011, 2018); en la reducción dramática del área de los glaciares andinos (ANA 2020) y la reducción de la disponibilidad de agua tanto superficial como subterránea (Muñoz 2016), en el aumento de los riesgos por huaycos y deslizamientos (Carey 2014), en la expansión incesante de la desertificación (MINAM 2011, Morales 2012) y, entre tantas otras manifestaciones, en el aumento de la frecuencia y del impacto de la erosión hídrica y eólica, especialmente severas en las llamadas tierras degradadas (Román et al. 2018, Sabogal 2018). Todo eso tiene repercusiones sociales y económicas enormes (Nkonya et al. 2016), por ejemplo, sobre la salud humana (Fraser 2009, Ye et al. 2021), la productividad agropecuaria, la pesca continental y marina y, en general, sobre la calidad de la vida de los peruanos, especialmente de los más pobres, de hoy y de mañana (Andersen et al. 2009).

El problema del deshielo de glaciares andinos es particularmente evidente y grave por su secuela de riesgos incrementados en forma de aludes, desbordes, contaminación natural, aumento de caudal de ríos costeros y problemas adicionales de salinización y anegamiento, o de los ríos amazónicos, con inundaciones mayores. A nivel nacional se ha perdido $42,6 \%$ de la superficie glaciar con respecto a lo registrado en el año 1970 (cerca de $871 \mathrm{~km}^{2}$ ). En el caso particular de la Cordillera Blanca, se estima que entre 1970 y 2010 esta ha perdido $34 \%$ de su superficie glaciar, y se observa que la mayor masa glaciar ya se derritió, dado que han desaparecido los glaciares de las zonas de menor pendiente; es decir, donde precisamente estos tienen su mayor espesor. Se estima que los glaciares por debajo de los 5000 m.s.n.m. habrán desparecido antes de 2030 (MINAM 2010, 2016c).

Por ser de actualidad se debe mencionar que otra consecuencia de la destrucción del recurso forestal natural es el incremento del riesgo de enfermedades nuevas. En efecto, la correlación entre destrucción y degradación de bosques tropicales y la pandemia actual ha sido bien demostrada (Brancalion et al. 2020) y, por tanto, debería ser otro sólido argumento para mantener una proporción razonable y en buen estado de estos.

Capítulo aparte es el tema de la pérdida de la diversidad biológica tanto en términos de pérdida de especies como de reducción de la densidad o número de individuos por especie (Herzog et al. 2011), afectando seriamente su aprovechamiento económico actual $\mathrm{y}$, en particular, sus beneficios potenciales. Ya hay evidencias de numerosas especies raras 0 amenazadas tanto de la flora como de la fauna (SERFOR 2018) y, de no adoptarse pronto estrategias basadas en más áreas naturales protegidas más extensas y en corredores ecológicos, especialmente altitudinales, el riesgo de perder especies es muy grande (Rodríguez y Young 2000). La rarificación se debe a la destrucción de sus hábitats y a la caza, la pesca, la extracción forestal y de productos naturales y, cada vez más, a la contaminación.

La fauna silvestre, pese a su importancia económica considerable, históricamente demostrada con el aprovechamiento del guano de islas, de la vicuña entre muchos otros casos, es un recurso tradicionalmente despreciado y relegado por el Estado, desperdiciando su contribución potencial al desarrollo económico y al bienestar social, especialmente para las poblaciones rurales, poniendo en riesgo su supervivencia (Brack 1986, Dourojeanni 1986b).

\section{Diminución de la cobertura de bosques y ecosistemas naturales}

La deforestación es el principal y más evidente problema de los bosques peruanos. La eliminación de los bosques y su reemplazo por diversas modalidades de agricultura y, más recientemente, por la minería ilegal, ha sido descrita, estudiada y reevaluada periódicamente a lo largo de los últimos 50 años (Malleux 1975; Dancé 1980; ONERN 1985; Dourojeanni 1976, 1990; Portuguez y Huerta 2005; MINAM 2016c; Finer y Mamani 2020). Los ecólogos estiman que en tiempos históricos los bosques aún cubrían naturalmente por lo menos unos 90 millones de hectáreas en todo el Perú (Weberbauer 1945, Tosi 1960, Sylvester et al. 2017). 
Pero en 2017, solo quedaban 68,6 millones de hectáreas (OSINFOR 2019) o menos (MINAM y PNCBMCC 2021b), en su mayor parte en la Selva (94,2\%). En ésta, según la versión oficial, hasta 2001 se habría deforestado alrededor de 7,2 millones de hectáreas (Portuguez y Huerta 2005). No obstante, si se acepta el criterio de los ecólogos, esta versión podría estar por debajo de la realidad (Dourojeanni 2019a). En efecto, los estimados previos de deforestación varían mucho según la línea base que se escoge, las técnicas y metodologías usadas y, en especial, el criterio preferido, por ejemplo, en lo referente a la definición de bosque y a la exclusión o inclusión de bosques secundarios.

A partir de 2001 no existen dudas significativas sobre la información de la deforestación anual gracias a las nuevas técnicas disponibles (Finer y Mamani 2020) y a los informes publicados periódicamente, quedando fehacientemente demostrado que en los últimos 20 años se ha deforestado 2,6 millones de hectáreas en la Selva, de las que más de 200 mil hectáreas fueron destruidas apenas en 2020 (Finer y Mamani 2020). Estos autores encontraron que 1,1 millones de hectáreas (24\%) de la tierra bajo uso agropecuario provino de la deforestación ocurrida entre 2001 y 2017. Según la información precedente, los bosques amazónicos peruanos habrían perdido 8,4 millones de hectáreas, lo que equivale al 14,2\% de la región Selva que, en la actualidad tiene, según fuentes oficiales, 72 millones de hectáreas. Pero, si los ecólogos están en lo cierto, el bioma amazónico peruano ha perdido mucho más, especialmente en la Selva Alta del norte y del centro del país.

En la Costa y en la Sierra la situación es obviamente peor. Se estima que los bosques secos constituyen el 4,7\% de los bosques del Perú. Un estudio de 1981 reveló que la superficie forestal de Tumbes, Piura y Lambayeque ya cubría apenas $40,9 \%, 4,7 \%$ y $0,04 \%$ respectivamente y que, entre 1970 y 1980 las áreas forestales de esos tres departamentos se habían reducido, respectivamente, en $14,8 \%, 25,8 \%$ y $46,2 \%$ (DGFF 1981). Actualmente los bosques secos de todo el país cubren 2376056 ha (MINAM 2016a, MINAM y PNCBMCC 2021a). Otros estimados referidos a todo el Perú, como los de Portillo-Quintero y Sánchez-Azofeifa (2010) ofrecen cifras más pesimistas. El caso de los manglares también es crítico, especialmente desde la expansión de la acuicultura de langostinos. En efecto, estos cubrían unas 28000 ha hasta comienzo de los años 1970 (Malleux 1975) y en la actualidad solo abarcan 5600 ha (MINAM 2015). El ecosistema conformado por las lomas costeras que habría ocupado unas 817000 ha (Tosi 1960) hoy posiblemente no abarque más de unas 250000 ha, repartidas en 67 fragmentos muy degradados, de los que Atiquipa es el más significativo. Es importante anotar que el $42 \%$ de la flora de las lomas está conformada por especies endémicas (MINAM 2019). En los Andes subsisten muy pocas áreas forestales naturales que puedan ser denominadas bosques. Subsisten rodales pequeños, degradados y aislados, es decir relictos, que cubrirían unas 800000 ha (MINAM 2016a, MINAM y PNCBMCC 2021a).

La expansión incesante de la agricultura sobre los bosques en la Selva ocurre, en parte, porque las políticas socioeconómicas no han dado alternativas a un amplio segmento de la población rural que vive en la pobreza y en la ignorancia y que apela a la deforestación como medio de sobrevivencia. Como es bien sabido gran parte de la deforestación es ilegal o, si se prefiere, es informal. Un estudio reciente (Dummett y Blundell 2021) estima que en el Perú el 66\% de la deforestación es para agricultura comercial pero que el $51 \%$ de esta es ilegal. El 80\% de la deforestación anual se realiza en parcelas de menos de cinco hectáreas cada una (Finer et al. 2018), cada año avanzando de 0,5 a menos de una hectárea, incluyendo la expansión de cultivos ilegales. Estos últimos ya ocupan más de 70000 ha (Prado 2020). Sin embargo, también se debe a la acción de agricultores con predios de tamaño medio, de algunas decenas de hectáreas y, asimismo, a grandes empresas nacionales e internacionales que buscan expandir sus oportunidades de negocios produciendo commodities, como aceite de palma o cacao, además de la deforestación causada por grupos religiosos (menonitas e israelitas). Según el estudio citado el $11 \%$ de la 
deforestación que es ilegal se debería a cultivos para exportación. Todos, ricos y pobres, expanden sus actividades sobre los bosques naturales en lugar de aprovechar la tierra ya deforestada. Y es importante recordar que en el caso de los pobres existen justificaciones diversas que, en virtud de la falta de tecnología apropiada, pueden estimular al agricultor a deforestar, practicando agricultura migratoria con largos periodos de descanso (Budowski 1962, Watters 1971, Menton y Cronkleton 2019).

Los motivos para deforestar, pese a los hechos citados, se deben a varios factores que están imbricados: (i) el Estado, a través de políticas, leyes e inversiones estimula abiertamente que eso ocurra, siendo en realidad, el principal promotor de la deforestación; (ii) la falta de oportunidades para gran parte de la población rural andina que se expresa en campesinos informales que migran a la Selva e invaden los bosques; (iii) la inexistencia de asistencia técnica y financiera para impulsar la producción y la productividad especialmente en Sierra y Selva; (iv) la lentitud del proceso de saneamiento de la propiedad de la tierra, así como la existencia de millones de hectáreas sometidas al régimen de "tierras de aptitud forestal" que por eso no pueden ser adjudicadas en propiedad y en las que no se hacen inversiones; (v) la impotencia institucional para aplicar las leyes que limitarían la deforestación y; (vii) la falta de conciencia nacional sobre las graves consecuencias de la deforestación (Dourojeanni 2019a, Suárez 2021).

El Estado está directa o indirectamente detrás de gran parte de las causas de la deforestación. El sector público agrario nacional y regional fomenta la expansión del área cultivada con café, cacao, arroz, palma y de varios otros cultivos, así como las áreas destinadas a la ganadería, como queda demostrado por los numerosos planes existentes para cada cultivo o crianza (MINAGRI 2002, 2008, 2015, 2016a, 2016b, 2017c, 2019). En ningún caso se exige que eso se haga sobre tierras deforestadas o se implemente algo serio para aumentar la productividad. En todos los casos de apropiación ilícita de tierras con bosques que son denun- ciados, las autoridades regionales defienden abierta o soterradamente a los infractores (Mongabay 2020). Es más, en la actualidad se vende tierra cubierta de bosques naturales, supuestamente con suelos de aptitud agropecuaria, a precios venales. El propio sector forestal está obsesionado con aumentar la producción de madera y no con la conservación del recurso, tema que deja al Ministerio del Ambiente. El país carece de un servicio de extensión agropecuaria digno de ese nombre y el financiamiento de los cultivos y crianzas es escaso y muy difícil, afectando tanto a los productores rurales pobres de Costa, Sierra y Selva. Al mismo tiempo no cumple su responsabilidad de titular y regularizar la tenencia de la tierra, proceso que se arrastra con avances limitados desde hace décadas. Lo mismo ocurre con el sector público minero que facilita abiertamente la ilegalidad de la minería comprando y legalizando el oro producido por la minería informal y que facilita la adquisición de insumos, como el mercurio y los combustibles, así como los equipos. En eso participa también el sector público financiero que no fiscaliza los movimientos de fondos, que demostrarían las ilegalidades y, obviamente, el de transportes, que sin planeamiento adecuado abre carreteras en bosques naturales y, peor, legaliza periódicamente la construcción de miles de kilómetros de carreteras informales (Dourojeanni et al. 2010). Y, claro, es decisión táctica del Estado mantener al Ministerio del Ambiente y a sus agencias con recursos presupuestales insuficientes para mínimamente cumplir las funciones para los que fueron creados. Pareciera, pues, que el Estado peruano conspira, unido, para la destrucción del patrimonio forestal nacional (Ráez 2016) apenas con la débil resistencia del Ministerio del Ambiente y, muy ocasionalmente, del Poder Judicial, del Ministerio Público y de la fuerza pública. Por eso es indispensable que la nueva política forestal sea verdaderamente nacional, integrada e intersectorial.

A lo anterior se suma una sociedad desinformada y desinteresada que parece satisfacerse con la publicidad ambiental estatal que hace creer que todo está bajo control o que, si se 
muestra alarmada, no encuentra eco en los partidos políticos o en los parlamentarios. Un ejemplo de esto han sido las campañas oficiales contra la "tala ilegal" que hacen creer que la explotación forestal es la causa de la deforestación, evitando mencionar a la expansión agropecuaria (Che Piu 2008b). Pero, en general, el pueblo peruano no se siente amenazado con los problemas ambientales. Encuestas realizadas anualmente desde 2007 nunca mostraron más de $11 \%$ de la población que considere la problemática ambiental como uno de los tres principales problemas del país (Ipsos 2020), y a la pregunta sobre los problemas que un próximo gobierno debe enfrentar prioritariamente el tema ambiental ni siquiera es mencionado.

\section{Creciente degradación del bosque y de otros ecosistemas}

La deforestación es apenas la parte más visible de los problemas relativos al bosque. El otro, igualmente importante, es la degradación, es decir la eliminación total o parcial de algunos de los elementos del ecosistema (especies de árboles y de otras plantas o de animales) o el deterioro del ecosistema por contaminación, compactación, recolección abusiva de frutos o semillas, fuego, etc. (Foley et al. 2007, Lund 2009, Vancutsem et al. 2020). Matricardi et al. (2020) sostienen que en el largo plazo la degradación puede tener más impacto que la propia deforestación. Como es obvio, la responsabilidad principal de la degradación del bosque es la extracción forestal maderera del tipo que se conoce como "descremado", es decir el retiro de árboles de las especies madereras valiosas que, periódicamente, son preferidas por el mercado. Esa forma de extracción provoca las llamadas "extinciones comerciales" por las que pasaron numerosas especies (palo rosa, romerillo, caoba, lupuna, tornillo, ishpingo) siendo actualmente el turno del shihuahuaco, preferido por chinos y otros clientes (Putzel et al. 2008, 2010; INIA 2020). Esas extracciones selectivas, el retorno periódico al bosque para extraerlas $y$ el fraccionamiento tienen un gran impacto en la biota (Broadbent et al. 2008, Putz y Redford 2010). La degradación es acentuada en los bosques donde la extracción es ilegal, pero es evidente también en los bosques comunales (Buendía 2014). Lamentablemente, los bosques de las concesiones forestales no escapan a la degradación debido a la mala calidad del manejo aplicado (Galarza y La Serna 2005; Kometter 2016, 2019; Dourojeanni 2020). Considerando la enorme amplitud territorial de las explotaciones forestales del pasado se puede estimar que no menos del $50 \%$ de los bosques que aún existen ya han sido degradados en alguna medida, fraccionándolos, alterando su composición y su dinámica, así como predisponiéndolos a incendios forestales y aumentando las emisiones de $\mathrm{CO}_{2}$ (Escobar 2019, Qin et al. 2021). A esa forma de degradación se suman otras, más evidentes, ocasionadas por deforestación y/o maltrato del suelo, tanto en la misma Amazonia como en otros biomas y ecosistemas naturales importantes.

Debido a este panorama es evidente que, si no se adoptan medidas urgentes, el bosque natural se acerca rápidamente a una situación irreversible, a partir de la cual los perjuicios de deforestar y degradar serán mucho mayores que los beneficios. La Amazonia peruana ya alcanzó, o está muy cerca del llamado punto de "no retorno" descrito, entre otros, por Lovejoy y Nobre (2020), a partir del cual será irreversible el proceso de sabanización, con gravísimas consecuencias sobre el ciclo hidrológico, además de liberar carbono y acelerar el proceso de cambio climático, con demostradas repercusiones sobre la economía y la sociedad. Duffy et al. (2021) presentan un escenario global aún más pesimista. Un estudio reciente confirma fuera de toda duda que la capa de la atmósfera encima de la Amazonia se ha desecado progresiva y significativamente durante los últimos 20 años, elevando la demanda de agua y dejando amplios ecosistemas vulnerables a las sequías (Barkhordarian et al. 2019) sin que para ello exista alguna explicación natural. Y esto, sin duda, favorece los incendios forestales.

\section{Aprovechamiento forestal insostenible}

Con relación a los problemas del aprovechamiento del bosque destaca el hecho de que no menos del $60 \%$ de la madera que se comer- 
cializa en el país no es "legal", existiendo referencias que citan cifras más elevadas, dependiendo del criterio o contexto aplicado (Pautrat y Lucich 2006; AIDESEP 2007; Che Piu 2008a, 2008b; Finer et al. 2015; Solís 2016; Global Witness 2019; Rosales 2019; García 2020; Urrunaga et al. 2020). Esto está en gran medida asociado al hecho de que el $96 \%$ de las empresas del sector forestal son miniempresas y que la informalidad empresarial y laboral en el sector presentan respectivamente tasas de $73 \%$ y 91\% (FAO 2018). El Organismo de Supervisión de Recursos Forestales y de Fauna Silvestre (OSINFOR) revela que, en promedio de 2015 a 2020, la mayor parte del volumen de árboles no autorizados detectados provino de bosques locales (37\%), comunidades nativas y campesinas $(36 \%)$, predios privados y otras modalidades (14\%), inclusive de las concesiones maderables caducadas (OSINFOR 2019). La ilegalidad o informalidad de la extracción maderera y la corrupción que le es asociada es, per se, un grave problema social y económico pero lo más importante es que por razones evidentes los que la practican no aplican un manejo forestal, por lo que esa explotación no es sostenible, siendo así la causa primordial de la degradación del patrimonio forestal nacional.

Obviamente, la ilegalidad es máxima en la madera destinada al consumo interno, que representa más del $90 \%$ de la producción (FAO 2018) y, es menor en la madera que se destina a exportación, caso en que es sometida a supervisión más estricta y que, en general, proviene de concesiones forestales. Pero aún en estas hay graves problemas que repercuten en el abandono de concesiones y en el carácter generalmente no sostenible de la extracción debido a deficiencias en el manejo. En efecto, diecisiete años después de iniciado el modelo de concesiones maderables sobre bosques supuestamente productivos, que en verdad no habían sido estudiados y cuyo verdadero potencial se desconocía (Salo y Toivonen 2009), y de haberse otorgado 827 de ellas, cubriendo 11,2 millones de hectáreas, a 2018 solo quedaban vigentes 427 (56\%) cubriendo 6,3 millones de hectáreas (Vergara 2019). Es preciso subrayar que parte del abandono de las concesiones forestales se debe a la competencia desleal creada por la informalidad.

Otra consecuencia de la informalidad es el desperdicio del recurso. Por diversos motivos, hasta $60 \%$ del volumen de los árboles que se talan es abandonado en el bosque y quizá un $20 \%$ de lo que es transportado es abandonado en el patio del aserradero por defectos, muchos de ellos ocasionados por métodos inadecuados de tala (Gauthier 1987, Colán et al. 2006). En la actualidad ese desperdicio debe ser menor. El aserrío representa el $90 \%$ del procesamiento de la madera, teniendo un desperdicio de alrededor del 50\% (Guevara et al. 1993). La suma de desperdicios, desde el bosque hasta el uso final es enorme.

\section{Degradación de la tierra y del paisaje}

La degradación de tierras en el Perú constituye un desafío de interés nacional que merece atención prioritaria. Se ha identificado recientemente que más de 6,3 millones de hectáreas en 17 departamentos tiene una alta a muy alta prioridad para restauración. Se estima que al ritmo actual de degradación (4,5\% al año) en 2100 este grave problema afectará al 38\% del territorio nacional, precisamente donde se asienta el $88 \%$ de la población y se desarrollan las actividades agrarias que generan el 9\% del PBI (Román et al. 2018). La degradación de tierras es consecuencia de actividades tales como la deforestación, la ampliación de la frontera agrícola, el cambio de uso de suelo, las malas prácticas agrícolas (salinización, alcalinización, contaminación, anegamiento, pérdida de nutrientes) y de pastoreo (pisoteo, uso de fuego, degradación de pasturas), la minería ilegal, los cultivos ilícitos (contaminación), la expansión urbana, entre otros. Afecta por igual a tierras de uso agropecuario o forestal y, asimismo, a las que se denominan eriazas. La expresión más evidente y común de la degradación de las tierras es la pérdida de los suelos, especial pero no únicamente por erosión hídrica y eólica de estos. Es decir que la degradación de la tierra, aunque frecuentemente vinculada a la del bosque, constituye un problema diferen- 
ciado que requiere una atención cada vez más urgente.

La degradación de tierras tiene un impacto importante en la reducción de la superficie apta para la producción agrícola, lo que afecta la seguridad alimentaria y crea necesidad de ampliación de la frontera agrícola, con lo que se estimula más la deforestación. Combatir la degradación de tierras tiene, asimismo, un impacto directo y positivo sobre la mitigación de impactos del cambio climático, la generación de empleos e ingresos, la ampliación de opciones para mejorar la calidad de vida de la población, así como para crear una mayor resiliencia o capacidad de recuperación de los ecosistemas y, a la vez, evitar que nuevas áreas se deterioren o degraden.

Por su importancia evidente, la restauración de ecosistemas ha sido incluida en la normativa peruana vigente (por ejemplo, en la Ley Forestal y Fauna Silvestre, la Ley General del Ambiente y la Ley de Cierre de Minas) pero la implementación de iniciativas de restauración aún es incipiente. De otra parte, el Perú ha establecido un compromiso a nivel internacional para la recuperación de 3,2 millones de hectáreas de tierras degradadas hasta el 2030, en el marco de la Iniciativa 20x20 y el Desafío de Bonn y la Declaración de Nueva York sobre Bosques de la Cumbre de las Naciones Unidas sobre el Clima de 2014. Las iniciativas de restauración de ecosistemas y tierras degradadas son parte de los acuerdos internacionales del país, tales como la Convención de las Naciones Unidas para la Lucha contra la Desertificación, las metas de Aichi, la Convención Marco de las Naciones Unidas sobre el Cambio Climático, la Convención de la Diversidad Biológica (CDB), contribuciones nacionalmente determinadas (NDC) y los Objetivos de Desarrollo Sostenible al 2030.

Respondiendo a esos hechos el gobierno ha preparado programas que procuran impulsar las muchas acciones necesarias (Román et al. 2018, Mamani et al. 2019). Lo que esta política propone es, en realidad, dar fuerza a esas propuestas que son muy completas. Permitirán enfrentar los desafíos relacionados con el cam- bio climático, mejorar la seguridad alimentaria, generar empleos e ingresos, ampliar opciones para mejorar la calidad de vida de la población, así como lograr mayor resiliencia o capacidad de recuperación de los ecosistemas, a la vez que evitar que nuevas áreas se deterioren o degraden, desde un enfoque de desarrollo territorial o de paisaje (Sabogal 2018). Sin embargo, como bien se sabe, todas esas proposiciones internacionales y nacionales, sin dudas válidas y de relativamente fácil aplicación han sido y continúan estando relegadas, permitiendo que la degradación continúe y se agrave.

\section{Pocas plantaciones forestales y desabaste- cimiento de madera y productos forestales}

Podría suponerse que el uso abusivo del bosque natural permitiría, por lo menos, atender las necesidades nacionales de madera y otros productos forestales. Pero no es así. A pesar de tener el $56 \%$ o más de su territorio cubierto de bosques, el país no se autoabastece de madera siendo un importador neto de productos forestales. No hay duda de que parte de la industria puede y debe basarse en la madera de origen natural, siempre y cuando esta sea sostenible, pero industrias como las de celulosa y tableros, entre otros, así como la madera de obra, dependen de grandes volúmenes de materia prima homogénea con abastecimiento previsible y asegurado. Ocurre que el Perú ha descuidado de un modo extremo el tema de las plantaciones forestales cuya producción es el principal abastecimiento de la gran industria maderera, inclusive en países con extensos bosques naturales, como Brasil.

El Perú ha sido incapaz de aprovechar unos diez millones de hectáreas de su territorio que, en Costa, Sierra y Selva, son reconocidamente aptas para la reforestación (MINAGRI 2005, 2020). Se declara, oficialmente, que existen 1074000 ha reforestadas (MINAGRI 2020) pero, en verdad, el Perú es uno de los países de América del Sur que cuenta con menos área relativa cubierta de bosques cultivados, de los que quizá apenas unas 50000 ha puedan ser consideradas industriales (MINAGRI 2020), quedando muy atrás de los países vecinos. Brasil, pese a poseer nueve veces más bosque 
natural amazónico que el Perú, ha plantado diez millones de hectáreas que le proveen la mayor parte de la madera que consume y exporta. El caso de Chile es similar, pues teniendo bosques naturales, ha plantado más de 2,5 millones de hectáreas. Son estos dos de los países de los que Perú importa productos forestales. En cambio, en nuestro país ha prosperado una reforestación poco tecnificada, frecuentemente asociada a la agricultura que, sin embargo, ha creado un comercio significativo de madera redonda y leña destinadas mayormente a la agroindustria, minería y para generación de energía, especialmente en La Libertad, Ancash, Junín, Apurímac y Cusco.

¿Por qué la reforestación está tan atrasada en el Perú? Los motivos son diversos, pero uno de ellos es porque la legislación ha negado persistentemente la titulación de tierras consideradas como de "aptitud forestal", negando seguridad jurídica a la inversión e impidiendo que en esas tierras se realicen inversiones privadas de medio o largo plazo, como las requeridas para la reforestación industrial. Dicho de otro modo, en lugar de favorecer el acceso de las plantaciones a la tierra disponible, se le ha dificultado. Además, por décadas se ha negado oficialmente a las plantaciones forestales el carácter de cultivos y, por lo tanto, se le ha impedido el acceso a beneficios económicos y fiscales que se brindan para la agricultura (Muñoz 2014). Asimismo, pese a ser una actividad económica de medio o largo plazo, las plantaciones forestales no han recibido incentivos económicos (líneas de crédito) o fiscales y otras garantías de apoyo del Estado, como las que en Brasil, Chile y Argentina permitieron impulsar la reforestación. El Estado tampoco ha conseguido brindar de modo continuo el apoyo técnico suficiente, incluyendo bancos de semillas y otros servicios indispensables. Finalmente, esa situación se debe en parte a que en las últimas dos décadas se ha producido una campaña de desinformación sobre el uso de especies exóticas como el eucalipto o el pino, basada en equívocos (FAO 2021a).

Por el motivo expuesto la producción nacional, según el SERFOR (2019) continúa siendo esencialmente leña (91\%) y madera aserrada (7,5\%). Treinta años atrás esos valores eran respectivamente $87 \%$ y $11,8 \%$ (DGFF 1991) mostrando que en lugar de mejorar la situación puede haberse agravado. Según las estadísticas del SERFOR (2019), el promedio anual de producción de madera rolliza entre 2016 y 2019 ha sido de 1,5 millones de metros cúbicos de madera rolliza/año.

\section{Industria forestal incipiente e ineficiente}

Por lo expuesto la industria nacional confronta gran dificultad para abastecerse de madera. Se caracteriza por su reducido aporte, tanto en la parte que atiende la demanda nacional como en la que se dedica a la exportación (Flores 2016). En verdad, la industria forestal peruana se ha contraído en lugar de crecer siendo su aporte actual al PBI muy bajo, habiéndose mantenido en alrededor de $1 \%$ o menos (INEI 2017, SERFOR 2018). Eso mismo ha ocurrido con el valor de las exportaciones que, en 2019 alcanzó apenas 125 millones de dólares, importando por un valor diez veces mayor. En 2020 las exportaciones sumaron US\$ 94 millones, mostrando una reducción del $24 \%$ respecto al año 2019 En el periodo 20162020 las exportaciones del sector evidenciaron un decrecimiento promedio anual del $7,1 \%$, probablemente debido a la pandemia de la COVID-19 (INEI 2020b).

La exportación está concentrada en productos semi-manufacturados $(64,5 \%$ del valor de las exportaciones) y madera aserrada (22\%). La industria de primera transformación de la madera peruana no ha evolucionado. Se continúa con el mismo formato de los productos de madera aserrada no estandarizados y, además, se comercializa con alto contenido de humedad. Muebles y partes de muebles, por ejemplo, sólo representan el 3,2\% del valor exportado (ADEX 2019). La industria produce y exporta laminados, pero los importa en mayor proporción. La importación se centra en tableros de Ecuador y Colombia y en celulosa de EE. UU. Y Canadá por un valor superior a los mil millones de dólares. También importa tablas, listones y vigas de pino radiata que provienen 
de Chile y que actualmente cubre más del 50\% de la demanda nacional, solo por el hecho de estar cortada en dimensiones estándar, seca y tratada. Es poca o nula la asistencia técnica y capacitación que reciben los industriales forestales que, en especial las de primera transformación, casi no absorben profesionales, siendo dirigidas por técnicos y operarios.

En 2015 existían unas 9000 empresas dedicadas a la extracción forestal de las que apenas el $40 \%$ eran formales. A ese año existían unas 18500 empresas dedicadas a la fabricación de productos de madera. Toda la cadena productiva de madera y derivados registraba para ese año un total de 84000 trabajadores de los cuales el $16 \%$ estaban dedicados en la extracción, $12 \%$ a la primera transformación de la madera y el $72 \%$ a la segunda transformación. De esta última, la "fabricación de muebles" reunía la masa crítica de trabajadores (45\%). No obstante, llevando en cuenta que la informalidad alcanzaba, en 2014, al 73\% de las empresas y al $91 \%$ de los trabajadores, el sector puede llegar a emplear 800000 personas.

\section{Abandono de ecosistemas naturales de Sierra y Costa y de los pastos naturales}

Por estar la mayor parte de los bosques naturales en la región Selva es evidente que parte considerable de las discusiones sobre una política nacional de bosques apuntan a su problemática particular. Pero, de una parte, existen recursos forestales considerables y particularmente valiosos en Costa y Sierra y, de otra, la mayor parte del patrimonio forestal natural que no es técnicamente bosque, pues no tiene árboles, se encuentra, precisamente, en esas regiones. De esos el ecosistema más importante está conformado por los pastos naturales que reúnen los recursos forestales más abandonados por el Estado, tanto que su gestión no ha sido legalmente asignada a ningún sector público, aunque, por razones obvias, corresponde genéricamente al sector agrario que, sin embargo, sólo se ocupa en cierta medida de los que son cultivados.

Este patrimonio, que cubre aproximadamente 22 millones de hectáreas, abarca la puna, dominada por pajonales, matorrales andinos, semi-desiertos andinos y por formaciones almohadilladas y, al norte, por el páramo, más húmedo. Ambos ecosistemas son de enorme importancia por sus servicios ecosistémicos, destacando su rol en la hidrología regional (Mosquera et al. 2021) y, también, económicamente, al servir como áreas de pastoreo. Las lomas costeras también han sido huérfanas de atención gubernamental hasta muy recientemente gracias, esencialmente, a iniciativas de la sociedad civil (SERNANP 2019). Gran parte de los pastos, como las lomas, presentan problemas de sobrepastoreo, siendo este la principal causa de los incendios forestales por el mal manejo de las técnicas de quemas. Una nueva institución forestal debería disponer de una dependencia especializada para atender el uso y la conservación de los pastos naturales, promoviendo su adecuado manejo, considerando que más del $95 \%$ son de propiedad de las comunidades campesinas.

Otro tanto acontece con los humedales, inclusive los enormes "aguajales" y "tahuampales" amazónicos que, aunque considerados como bosques, carecen de la atención especializada que ameritan por su importancia económica y ecológica. La vegetación ribereña de Costa y Sierra es igualmente sub atendida por los órganos oficiales pese a su carácter decisivo para evitar desbordes y controlar la erosión.

De otra parte, la carencia de bosques naturales en Costa y Sierra hace tanto más importante a las plantaciones forestales y, de hecho, la mayor parte de las tierras de aptitud para esta actividad que es tan necesaria en lo económico como en lo social, se encuentran precisamente en la Sierra y especialmente en tierras de las comunidades campesinas, en las que se encuentra gran parte de las plantaciones actuales. Se estima que en esta región existen 7,5 millones de hectáreas aptas para ese fin (MINAGRI 2005). Las necesidades de reforestación con fines de restauración de tierras degradadas son de enorme relevancia en la Sierra para frenar procesos erosivos violentos.

Finalmente, el Estado debe aunar esfuerzos para solucionar los problemas de la Sierra no 
solamente porque su población es grande y pobre, sino también porque si se brindan alternativas de crecimiento económico y desarrollo social en esta región, se contribuirá a disminuir la migración hacia la Selva, limitando así la deforestación. Es decir, el potencial forestal de la Sierra es grande y actualmente se encuentra muy despreciado.

\section{Políticas y leyes que no se aplican e insti- tuciones inoperantes}

Todos los problemas mencionados, el maltrato del bosque, el dominio de la informalidad, la corrupción y la insignificancia del aporte del sector forestal a la economía nacional, así como al desarrollo social se deben, en gran medida, a la incapacidad del Estado para hacer una gestión acorde a la importancia de los bosques. La historia muestra periodos en los que la gestión del bosque fue mejor que en otros (Dourojeanni 2009b). Hasta fines de la década de 1970 existía una sola institución pública nacional (el Servicio Forestal y de Fauna hasta 1969 y la Dirección General Forestal y Fauna hasta 1992) a cargo del sector forestal que tenía amplio espacio e influencia dentro del sector agrario. Desde entonces el sector fue siendo debilitado y fracturado tanto a nivel nacional dividiendo las instituciones (Instituto Nacional Forestal y de Fauna, Instituto Nacional de Recursos Naturales ambos, en su momento, en adición a una Dirección General Forestal y de Fauna) como al regional, con el proceso de regionalización y la consecuente descentralización y desconcentración de la autoridad.

A partir de la década del 2000, con el crecimiento del interés por la temática ambiental, la gestión de los bosques fue aún más parcelada, esta vez en dos sectores públicos (agricultura y ambiente) y, luego, debido a la preocupación por la corrupción en el sector y por la deforestación, se le dividió en tres, otorgando parte de la responsabilidad al Organismo de Supervisión de los Recursos Forestales y de Fauna Silvestre (OSINFOR), el cual es un órgano dependiente de la Oficina del Primer Ministro y, asimismo, a una Comisión Multisectorial Permanente de Lucha Contra la Tala Ilegal
(CMPLCTI) que controla el Sistema Nacional de Control y Vigilancia Forestal y de Fauna Silvestre (SNCVFFS). O sea que, en la actualidad, el recién recreado Servicio Forestal y de Fauna Silvestre (SERFOR), como en su versión anterior (1961-1969) está vinculado al sector agrario y comparte la responsabilidad con los ya mencionados OSINFOR y la Comisión Multisectorial, y también con un importante y amplio Programa Nacional de Conservación de Bosques para la Mitigación del Cambio Climático (PNCBMCC) que depende del sector ambiente. Obviamente, esa estructura nacional se repite, en una u otra medida, en cada región.

Es decir que, en la actualidad las instituciones del sector forestal están dispersas e inconexas, son muy débiles, con presupuestos insuficientes (Corderi y Goy 2017) y, por ende, la ineficiencia alcanzó un nivel extremo (Pautrat et al. 2010). Las raíces de esta situación incluyen una sociedad nacional que, en general, es desinformada y, en especial, indiferente, junto con un Estado que no se articula para combatir la deforestación, que es la expresión más clara del desastre ambiental anunciado.

De otra parte, es evidente el continuismo de la política forestal y de la legislación en el Perú, todas ellas basadas en la primera ley (Ley 14552 de 1963). Aunque las siguientes cuatro leyes (Ley 21147 de 1975, Ley 27308 de 2000, Decreto Ley 1090 de 2008 y Ley 29763 de 2011, sin mencionar la Ley 29317 de 2009, que modificó artículos del Decreto Ley 1090) fueron más completas y copiosas y que, algunas de ellas, aportaron algunos cambios interesantes, es innegable que siguieron el mismo patrón: (i) la vocación de los bosques naturales es casi exclusivamente la madera, (ii) los bosques naturales son patrimonio de la Nación y no hay propiedad sobre ellos, (iii) las tierras de aptitud forestal son parte del patrimonio forestal nacional y no pueden ser otorgadas en propiedad, (iv) se otorga la extracción de madera en base a contratos o concesiones forestales, lo que en realidad es lo mismo; (v) a partir de la ley del 2000, al eliminar los bosques nacionales, la responsabilidad del manejo forestal se 
cargó exclusivamente al sector privado, (vi) las exigencias y complicaciones burocráticas son mucho mayores que los incentivos, (vii) todas propusieron opciones similares para resolver el problema de los pequeños extractores pero ninguna funcionó; (viii) todas declaran favorecer la reforestación pero ninguna estableció medidas concretas para lograrlo, (ix) todas relegaron el tema de la fauna silvestre $\mathrm{y},(\mathrm{x})$ todas se diseñaron esencialmente centradas en la Selva. Asimismo, es curioso que el tema fundamental para detener la deforestación no ha sido tratado específicamente en ninguna de las legislaciones previas, excepto parcialmente en lo referente a reglas para el cambio de uso de la tierra. Esas políticas y legislaciones, pese a sus declaraciones e intenciones, no han resuelto temas como la situación de los pequeños extractores y ribereños, no han brindado condiciones apropiadas para el desarrollo de las plantaciones forestales con fines industriales, y no han ofrecido alternativas concretas y económicamente atractivas a la agricultura migratoria o a la minería aluvial practicadas por campesinos andinos pobres. Tampoco han estado siquiera integradas a la política sectorial agraria, sector del que dependen. Menos aún, han incluido una estrategia para que las comunidades nativas y los pueblos ribereños puedan usar bien y conservar sus bosques. Ha habido pocas innovaciones útiles, que deben ser preservadas y eventualmente mejoradas, como el caso de las concesiones de conservación y ecoturismo.

Es de notar que la única ley que duró un periodo de tiempo razonable fue la de 1975, con 25 años de aplicación. La legislación vigente, la de 2011, es la más compleja, copiosa y confusa que se haya producido hasta la fecha y su aplicación es muy limitada por estar sujeta a interpretaciones, especialmente por su carácter excesivamente teórico. Sus reglamentos, con varias centenas de artículos y sus múltiples instructivos son de inspiración esencialmente burocrática (Dourojeanni 2013a, Che Piu 2018). Además, esa legislación tiene una base legal conformada por no menos de 21 textos legales y por otros 22 complementarios, además de su deber de respetar nada menos que 18 tratados y con- venciones internacionales, en su mayor parte vinculantes y que no se reflejan bien en la legislación nacional.

¿Existe actualmente una política forestal? En teoría existe. Pero es esencialmente una réplica, apenas con diferencias semánticas, de una decena de políticas, estrategias y planes anteriores que abarcaban todo el sector o partes importantes de este (DGFF 1974, 1987; MINAGRI 2002, 2005, 2017a; SERFOR 2020) y, en el caso de la política vigente, emana de la ley que la originó (MINAGRI 2020). Ocurre que, salvo las dos primeras legislaciones (las de 1963 y 1975), todas las demás leyes precedieron a las políticas. La penúltima ley fue el resultado de presión internacional y la última fue, en cierta medida un reflejo a los trágicos sucesos de Bagua. Aunque explicable, es evidente que hubiera sido mejor que el diseño de las políticas anteceda al de las leyes ya que, en principio, éstas se hacen para aplicarlas (FAO 2010a, 2010b, 2021b). Dicho de otro modo, la política forestal actual no dice nada errado. Sus objetivos son deseables. Pero, como se observa en la ley de la que se desprende, es más de lo mismo. Carece de una estrategia coherente y convincente, no quiebra el statu quo, y en muchos casos, no responde a la realidad. Además, lo mejor de ella no se aplica (Arce y Dourojeanni 1990, Dourojeanni 2013a, Che Piu 2018).

No puede soslayarse el tema de la corrupción en el sector forestal que, obviamente, es uno de los reflejos de la informalidad y de una legislación sobre reguladora, confusa y difícil de aplicar. Los escándalos que han impactado el sector forestal han sido recurrentes, tanto los de pequeña escala, pero muy generalizados, como en casos importantes y de repercusión internacional, habiendo sido a veces asociados al narcotráfico a través de mecanismos de lavado de dinero ilegal (Sierra 2018, 2019a, 2019b, 2020; Global Witness 2019; Urrunaga et al. 2020). Pero la forma peor y más generalizada de corrupción es la llamada pasiva, en la que funcionarios sin motivación evitan cumplir sus deberes para no enfrentar problemas (Dourojeanni 2019c), facilitando el tan dañino comercio ilegal de madera (SPDA 2019). El tema de los 
planes de manejo fraudulentos (Alianza Periodística 2021) es particularmente grave pues impacta directamente en la sustentabilidad del uso de los bosques y en los servicios ambientales que se espera de ellos. Los mismos problemas que se presentan en el aprovechamiento maderero, son recurrentes asimismo en el caso del de los productos forestales diferentes a la madera (Barriga 2014). Entre ellos el plagio de planes de manejo, la adulteración de datos y la subvaluación. La explotación de estos recursos sin manejo y sin reposición, ha traído la rarificación de numerosas especies muy valiosas, entre ellas la uña de gato y, antes, del árbol de la quina (Barriga 2020, Gómez y Gómez 2020).

Entre 2009 y hasta 2018 la cooperación internacional ha brindado al desarrollo forestal peruano, esencialmente a través del MINAM y del SERFOR (y sus versiones previas) unos US\$ 418 millones de dólares en forma de 47 proyectos desarrollados o en ejecución hasta 2025, excepto uno que terminará después. En realidad, ese es un valor parcial pues existen aportes que se catalogan bajo otros rubros de cooperación. De los mencionados, ocho operaciones, por un valor de US\$ 225 millones de dólares están en ejecución. La ayuda bilateral apoyó 37 proyectos por US\$ 322 millones de dólares, mientras que la multilateral sumó 10 proyectos por un valor de 68 millones de dólares. La cooperación financiera sumó US\$ 251 millones, mientras que la cooperación técnica alcanzó US\$ 94 millones y la mixta unos US\$ $68 \mathrm{mi}-$ llones. Las diferencias en números y valor corresponden a proyectos de organizaciones no gubernamentales. Los mayores aportes bilaterales tanto financieros como de cooperación han sido de Alemania, Japón, EE. UU., Noruega y Suiza, mientras que los principales aportantes multilaterales han sido la Corporación Andina de Fomento, el Banco Interamericano de Desarrollo, las Naciones Unidas (FAO, PNUD), el Banco Mundial y, entre otros, la Organización Internacional para las Maderas Tropicales (ITTO), además de diversas organizaciones no gubernamentales internacionales. La inmensa mayoría de los proyectos se han orientado a la Selva, fundamentalmente en Ucayali, Loreto, Madre de Dios y San Martín (Cubas 2018).
El apoyo internacional, sin ser determinante, es significativo en proporción al presupuesto público destinado a los bosques y es fundamental por enfocar aspectos particularmente importantes y mal atendidos por el presupuesto público ordinario. Sin embargo, existen evidencias de que estos recursos no son bien aprovechados. Las operaciones demoran en comenzar y se dilatan en el tiempo, las metas son frecuentemente reajustadas y en algunos casos sus objetivos se modifican. La gestión de esos recursos suele ser burocrática, con gran parte del gasto en las capitales. Los resultados, para muchos observadores, son insatisfactorios, muy por debajo de lo esperado por los donantes o aportantes de fondos. De una parte, es evidente que ante las ofertas de apoyo las autoridades nacionales de turno diseñan operaciones ad hoc, más para captar los recursos que para responder a prioridades y necesidades reales o que, en cambio, corresponden a los criterios e intereses de los aportantes de fondos. De otra parte, los proyectos suelen ser mal diseñados, sin correlación con otras acciones, reflejando la falta nacional de políticas y planes coherentes en el sector. Se ha mencionado que algunos proyectos parecen "listas de compras". Los problemas citados han llevado a los actores de la cooperación técnica y financiera internacional a crear una "mesa verde para los bosques" con el fin de coordinar y articular esfuerzos, evitar duplicaciones, efectuar un mejor monitoreo y evaluación de las operaciones y difundir mejor los resultados.

\section{Investigación, educación y formación insufi- cientes o inadecuadas.}

Existe, claro, investigación forestal en el Perú, tanto a cargo de las instituciones públicas de investigación de los ministerios responsables, como de las instituciones universitarias y, muy poco, por empresas privadas y en este caso mayormente sobre temas de plantaciones forestales. Pero aun sumando todo lo que se hace con mucho esfuerzo, el resultado es muy pobre $y$, especialmente en la academia, es a menudo de baja calidad y desconectado de problemas realmente importantes o urgentes. De cualquier modo, la inversión pública en investigación 
forestal está muy por debajo del mínimo necesario (SERFOR 2020). Notoria es la dificultad creciente para mantener áreas de investigación de largo plazo, con parcelas de crecimiento y otros trabajos indispensables, siempre vulneradas por invasiones (Dourojeanni 2009b, 2017), así como por el desinterés y falta de continuidad de las autoridades.

En las décadas de 1960 a 1980, con asistencia técnica internacional, fueron creadas escuelas o centros de capacitación permanente de operarios y de técnicos forestales las que, pese a su indudable éxito en formar personal altamente calificado, fueron todas abandonadas (Shirley 1968; Dourojeanni 1986a, 2009b; Malleux 2013; OSINFOR 2017). Las causas principales fueron, de una parte, su desconexión con la industria forestal que no participó en su diseño ni en sus costos y que no compensó justamente el servicio que ese personal ofrecía. De otra parte, se debe al desinterés de los sucesivos gobiernos que nunca integraron esas operaciones a sus obligaciones y que tampoco les dedicaron presupuestos regulares, a pesar de estos ser relativamente bajos. Por eso parte de los técnicos prefirió buscar títulos universitarios, y algunas de esas iniciativas dieron lugar a facultades forestales.

La educación forestal se concentra al nivel universitario en cinco facultades de ciencias o ingeniería forestal. Pero también existen seis que ofrecen la carrera de ingeniería ambiental y forestal. Además, hay 41 carreras aprobadas de ingeniería ambiental más otras 18 con combinaciones variadas (SUNEDU 2019). Con pocas excepciones, el nivel académico de las carreras de ingeniería forestal es bajo y carente de experiencia práctica. Pero la formación en el área forestal que ofrecen la mayoría de las otras 59 carreras es mínima, puramente teórica y absurdamente por debajo de las necesidades de la realidad forestal nacional. Sin embargo, sus egresados compiten por empleo de igual a igual con los verdaderos profesionales del área.

Es decir que la realidad actual es que, de una parte, existe sobreproducción de ingenieros que en su inmensa mayoría no tienen capaci- dad técnica para cumplir las funciones que el manejo forestal demanda. De otra, se mantiene un enorme déficit de profesionales de mando medio o peritos y de operarios calificados en temas del campo, como afilado, identificación de especies forestales en campo ("materos"), viveros, inventarios forestales, censos, etc. Un estudio relativamente reciente sobre esta problemática (SERFOR/GIZ 2016) recomienda especialmente reforzar la relación entre las empresas demandantes del servicio y las instituciones, así como hacer un mejor seguimiento sobre los egresados. Tampoco existe en el Perú nada equivalente a los guardabosques (o custodios forestales) que, en gran parte del mundo, son pieza clave del manejo forestal. Curiosamente, existen guardaparques que están en proceso de reconocimiento profesional y de disponer de un escalafón, de condiciones dignas de trabajo y de un centro de formación (MINAM 2016a, MINAM y PNCBMCC 2021a). En cambio, se han iniciado esfuerzos para que los propios indígenas actúen como custodios de sus bosques.

Los ingenieros forestales, debido a las restricciones presupuestales en los centros académicos, reciben mucho menos entrenamiento de campo que el mínimo necesario y eso ocurre por igual en las universidades localizadas en regiones forestales como en las que están en Lima u otras grandes ciudades. El programa de estudios en las facultades forestales con pocas variantes sigue el mismo patrón que fue aplicado a comienzo de la década de 1960 en la Facultad de Ciencias Forestales de la Universidad Nacional Agraria La Molina y que merece revisiones profundas y adaptaciones regionales que no se hacen en la medida suficiente. La Facultad citada es una de las pocas que ha hecho, en 2019, una discreta actualización de su plan de estudios. Una de las principales carencias se da, precisamente, en las materias de manejo forestal que deberían ser el eje de la formación. Pero hay deficiencias variadas, entre otros en los temas económicos y en lo referente a desarrollo sostenible (Malleux 2013, Sabogal 2019). Es también probable que deba separarse la formación de silvicultores de la que se debe im- 
partir a los que se dedicarán a manejo forestal de bosques naturales. Obviamente, los temas de industria forestal y de conservación forestal ya están bastante separados. El posgrado, en el país o en el exterior, está bastante difundido, pero, en el caso de los graduados en las universidades nacionales, hay poca evidencia de adquisición de conocimientos realmente nuevos ya que los profesores son los mismos. Los que se hacen en el exterior, en cambio, suelen ser muy especializados y más útiles para la investigación que para la gestión.

De otra parte, en el sector forestal prima la ciencia positivista de carácter disyuntivo, reduccionista, lineal y determinista (Arce 2019, Arce y Soria 2019). Esta situación les da un carácter muy disciplinario a los actores forestales existiendo poca predisposición a entender y considerar a otras disciplinas para tener un enfoque sistémico. Existe además la errónea creencia que las ciencias forestales no tienen nada que ver con la filosofía, con la ética, con la estética recortando su carácter de ciencia abierta. De esta manera los esfuerzos para revisar la epistemología de las ciencias forestales y la ontología que predomina en la relación seres humanos y bosques son muy incipientes, apenas realizado por algunos profesionales forestales que son considerados marginales a la corriente principal de pensamiento forestal. Esto debe superarse para estar a tono con la complejidad de los retos de la época. Por ejemplo, es casi inexistente las discusiones sobre la mercantilización de la naturaleza y se desconocen las implicancias de hablar de "recursos forestales" (Arce 2019, Arce y Soria 2019).

\section{Las respuestas}

\section{Una política para los bosques verdadera- mente nacional, integral y transectorial}

En el pasado prácticamente cada gobierno ha preparado una política forestal, limitada al pequeño, débil y aislado sector forestal, al que se le encarga una misión claramente imposible. Por eso, esas políticas no tuvieron influencia en las decisiones que hubiesen determinado su éxito y que corresponden al Estado en su conjunto. Si se desea el éxito es necesario que la política para los bosques corresponda tanto o más a otros sectores que al forestal. Además, debe ser realmente nacional, para todo el Perú y no casi únicamente para la Selva; también integral, completa sin restricciones y; obviamente, transectorial. Enfrentar el problema de la deforestación, cuya solución extrapola largamente la responsabilidad y la capacidad del llamado sector forestal o del ambiental, inclusive del agrario, es la mejor demostración de la necesidad de una política de Estado.

La solución de este problema apela a la intervención de los sectores responsables directos por las políticas que rigen las actividades que deforestan (agricultura, minería) y, asimismo, al sector transporte, que, indirectamente, mediante la construcción de vías de comunicación, especialmente carreteras, es el principal facilitador de esas actividades. Hasta el presente el tema de la deforestación es típicamente un "problema de todos y de nadie". No existe un sector de la administración pública que responda directamente por eso ante la sociedad. Sin embargo, cuando se buscan culpables, el asunto siempre recae en el reducido sector forestal y, desde hace un par de décadas, también en el igualmente mal equipado sector ambiental (Ráez 2016, Corderi y Goy 2017). Es decir, en dos sectores que no tienen capacidad o autoridad para resolverlo. La deforestación y la degradación del patrimonio nacional forestal afectan y comprometen el futuro de todos los peruanos. Deben ser entendidos como un problema de Estado.

Por eso, la propuesta aquí defendida incluye, expresamente, a los ministerios de Agricultura, Ambiente, Energía y Minas y Transportes, de modo indisociable, a la política nacional de bosques. Sin la participación activa de esos sectores es fútil pretender diseñar una "política forestal". Pero, en verdad, no son éstos los únicos sectores que son responsables. Dada la extrema complejidad social y económica del proceso de la deforestación (Margulis 2003, Fearnside 2008b, Dourojeanni 2019a) la tarea de evitarla corresponde a todo el gobierno en su conjunto, o sea, a todos los sectores públicos, así como a 
los tres poderes del Estado, decidir el destino de los bosques y asumir las consecuencias de no hacer nada para evitar su desaparición.

\section{Redefinir el patrimonio forestal nacional}

La Constitución (artículo 66) establece que los recursos naturales, renovables y no renovables, son patrimonio de la Nación. A partir de ese enunciado, la legislación forestal vigente (ley 29763 de 2011) determina (artículo 4o) que el patrimonio forestal y de fauna silvestre incluye: (i) los ecosistemas forestales y otros ecosistemas de vegetación silvestre, (ii) los recursos forestales y de fauna silvestre "mantenidos en su fuente", (iii) la diversidad biológica forestal y de fauna silvestre, incluyendo sus recursos genéticos asociados; (iv) los bosques plantados en tierras del Estado, (v) los servicios de los ecosistemas forestales y otros ecosistemas de vegetación silvestre; (vi) las tierras de capacidad de uso mayor forestal y tierras de capacidad de uso mayor para protección, con bosques o sin ellos y; (vii) los paisajes de los ecosistemas forestales y otros ecosistemas de vegetación silvestre en tanto sean objeto de aprovechamiento económico. La ley excluye las plantaciones forestales en predios privados y comunales y aunque sus productos se consideran recursos forestales, no son parte del patrimonio forestal y de fauna silvestre de la Nación.

Se trata, en esencia, de la misma definición de patrimonio forestal y de fauna silvestre vigente desde la ley de 1975 que ha sido útil, pues ha evitado que en la Selva existan abusivamente grandes propiedades rurales con o sin bosques. Establece, correctamente, que los bosques y otros ecosistemas naturales son patrimonio de la Nación. Pero, inadecuadamente, incluye asimismo las tierras cuya capacidad de uso mayor es forestal, sea esta de producción o de protección, con bosques o sin ellos y, también a los bosques plantados en tierras públicas. Tampoco tiene lógica que la inclusión de los paisajes de los ecosistemas forestales y otros ecosistemas de vegetación silvestre sea aplicable únicamente si son objeto de aprovechamiento económico. Asimismo, resulta técnicamente discutible declarar a los servicios ambientales como patrimonio forestal.
El tema de las tierras con capacidad de uso mayor forestal o de protección es extremamente importante pues, su aplicación constitucional y legal limita o impide el aprovechamiento de alrededor de diez millones de hectáreas que ya no tienen bosques. Ese hecho tiene su origen a fines de los años 1960 cuando la antigua Oficina Nacional de Recursos Naturales (ONERN) adecuó al Perú una metodología norteamericana de clasificación de tierras (Zamora 1971) que permitía determinar rápidamente y a bajo costo su fertilidad o aptitud natural y por ende su viabilidad ecológica y económica para diversas actividades económicas, en especial asentamientos rurales o colonizaciones. Esta fue plenamente adoptada en 1975 por el Ministerio de Agricultura y transformada en la primera versión del Reglamento de Clasificación de Tierras por Capacidad de Uso Mayor, que fue un anexo de la ley forestal de ese año. Durante mucho tiempo ese reglamento y sus sucesivas revisiones fueron una herramienta eficaz para justificar evitar la transformación masiva de bosques en tierras de cultivo o pastos. En efecto, aún en su cuarta aproximación (ONERN 1982) que ya restringía menos el uso agropecuario, se determinaba que solamente el $3,2 \%$ de los suelos amazónicos podrían ser usados para cultivos en limpio, 2,9\% para cultivos permanentes y $7,6 \%$ para pastos. El 51,5\% de la Amazonia peruana era considerado apto para uso forestal y el $25 \%$ restante debería ser protegido dada su susceptibilidad a la erosión. Este reglamento se convirtió, pues, en una barrera efectiva para evitar la expansión del modelo de colonización adoptado por la reforma agraria del gobierno militar de Velasco, y luego para limitar los grandes proyectos de colonización de Belaúnde. Pero nunca evitó la deforestación ocasionada por los pequeños agricultores invasores.

Como algunos científicos lo predijeron (Alvim 1972, Sanchez 1976, Sanchez et al. 1982) ese reglamento fue perdiendo vigencia en la medida que la tecnología agronómica, las nuevas variedades de plantas cultivadas y, en especial, la realidad económica (mayor demanda, costos menores) y la misma sociedad cambi- 
aron (aumento de población, presión sobre la tierra). Según Sanchez (1979) hasta el 77\% de la Amazonia peruana podría ser aprovechada para agricultura y ganadería aplicando prácticas agronómicas sostenibles relativamente simples. En la actualidad el tal reglamento está técnicamente obsoleto $y$, en lugar de servir al propósito para el que fue adoptado, ahora contribuye a justificar la ampliación de la frontera agropecuaria sobre bosques naturales valiosos (Che Piu y Galván 2015, Dammert 2015, Salazar y Rivadeneyra 2016) contradiciendo el creciente consenso sobre la necesidad de protegerlos.

Por eso, esta propuesta redefine el concepto de patrimonio forestal nacional. Este debe, además de incluir los bosques naturales, a todos los demás ecosistemas naturales continentales de todo el territorio nacional. Es decir, incluye los pastos naturales (puna, jalca, páramo), las lomas costeras, los rodales de puya, los tilandsiales, los campos de cactáceas y los humedales, entre otros ecosistemas naturales. Es preciso recordar que los bosques y otros ecosistemas naturales están conformados por la biocenosis, es decir la flora y la fauna, como por el biotopo que los soporta, es decir los suelos o la tierra y las aguas que los abastecen.

En cambio, se propone que deje de incluir los suelos de aptitud forestal que nunca tuvieron o que ya no tienen vegetación natural quedando, por lo tanto, innecesario el reglamento de clasificación de tierras vigente. Eso implica, lógicamente, que las tierras conocidas como de aptitud forestal podrían ser otorgadas en propiedad si así se decidiera. Obviamente, los bosques cultivados no deben formar parte del patrimonio forestal, estén donde estén.

\section{Consolidar el patrimonio forestal nacional}

El patrimonio forestal nacional está conformado por los bosques y otros ecosistemas naturales continentales, la tierra en que se encuentran y la fauna que habita en ellos, incluyendo las áreas naturales protegidas nacionales o regionales. Este patrimonio debe ser catastra- do (Catastro Nacional, Servicio Nacional de Catastro) y registrado como bien público (Registro Nacional de Bienes Públicos, Superintendencia Nacional de Bienes Estatales), procesos iniciados pero que no están concluidos. Pasos previos son: (i) concluir la zonificación forestal, que diferencia los bosques de producción y de protección, así como los bosques reservados (áreas naturales protegidas, de todas las categorías y tipos), los bosques y otros ecosistemas naturales incluidos en las comunidades nativas y campesinas; (ii) comenzar por la inscripción en el Catastro Nacional de todas las unidades que integran el Programa Nacional de Bosques (54 millones de hectáreas), como base del patrimonio forestal y; (iii) especificar los alcances del patrimonio forestal nacional ${ }^{1}$.

La estabilidad de la propiedad de la tierra es pieza esencial para la consolidación del patrimonio forestal nacional y para que se hagan inversiones con seguridad en las tierras que son privadas. De otra parte, la confusión y la sobreposición de derechos es enorme (Oliveira et al. 2007, Anderson et al. 2018). Por eso, es indispensable concluir el registro público de las comunidades nativas y campesinas y de la propiedad privada en las áreas deforestadas, de tal modo que, sumado a la consolidación del patrimonio forestal nacional (Malleux 2008) y de las tierras públicas, se establece un ordenamiento territorial de facto. Concluir la titulación de comunidades nativas y campesinas en la Selva puede requerir establecer una comisión nacional de demarcación y delimitación de tierras pues los reclamos para reconocimiento y titulación de nuevas comunidades son enormes. En efecto, existen reclamos por atender sobre más de 5,7 millones de hectáreas para comunidades nativas y sobre 4,8 millones de hectáreas para las campesinas (IBC 2016). La titulación debe incluir la eventual revisión y confirmación de la dimensión de la cesión en uso de áreas forestales a las comunidades nativas de las áreas con bosques. Los derechos de uso y los deberes de las comunidades con relación el recurso forestal cedido será defini-

\footnotetext{
${ }^{1}$ Por ejemplo ¿hasta qué punto los desiertos son parte del patrimonio forestal nacional? ¿Qué características de la vegetación determinan su inclusión o exclusión como patrimonio forestal en el caso de ecosistemas ligeramente antropizados?
} 
dos en la nueva legislación forestal pero el principio es que esos bosques tampoco pueden ser sometidos a cambio de uso de la tierra, salvo excepciones consideradas en la ley y que, más bien, en ellos se fomentará el manejo sostenible para producción forestal. De otra parte, existe una proliferación de comunidades nativas nuevas, fruto de desavenencias internas o de la falta de tierras y, asimismo, promovidas e integradas por personas inescrupulosas que se hacen pasar por nativos, siendo este un tema muy delicado, relevante también por su relación con la deforestación. Para reducir este tipo de situaciones se propone realizar previamente un censo detallado de las poblaciones de pueblos originarios y un inventario de las superficies que ocupan y reclaman.

El tema de la titulación en tierras ya deforestadas es importante y complejo. Se estima que en la Selva exista un poco más de diez millones de hectáreas deforestadas (MINAM 2021), ocupadas, pero sin dueños formalmente establecidos. Para su entrega a los ocupantes y su titulación, como propuesto, se debería conformar una comisión nacional para ordenar y supervisar el proceso, estableciendo las normas y procedimientos de titulación. Se prevé que pueda titularse sobre tierras con bosques antropizados, sean estos bosquetes residuales y aislados, degradados y secundarios ${ }^{2}$, o en mosaicos agroforestales, culminándose con el registro de la titularidad en Registros Públicos. En casos de abandono o ausencia de posesionarios, esos terrenos podrían ser vendidos. La nueva legislación forestal deberá incorporar las condiciones o salvaguardas ambientales necesarias para evitar que la titulación de esas áreas se convierta en un incentivo a la deforestación. De otra parte, se estimulará que en las propiedades que aún mantengan rodales forestales (bosquetes) se haga uso sostenible de los mismos, bajo el ordenamiento estipulado por las normas forestales generales. La agroforestería, con más árboles, es una excelente oportunidad para esas propiedades.

Otro tema importante para el sector forestal pero siempre relegado en las políticas del pasa- do, es el de los ribereños amazónicos. El IBC (2016) estima que existen 2400 comunidades ribereñas, asentadas a lo largo de los ríos de la Selva. Están en villorrios, aldeas o caseríos, unos mayores que otros y conformados por mestizos e indígenas que viven fuera de sus comunidades originales. Ellos se dedican a la agricultura de panllevar, a la pesca y a la caza de sustento, pero gran parte de sus ingresos provienen de la actividad forestal, en especial la extracción de madera y a colecta de productos forestales no maderables. Ellos conforman el grueso de la informalidad del sector, en lo referente a la extracción, trabajando en pequeños grupos o enganchados como operarios de microempresas extractoras de las ciudades próximas. Hasta el presente muy pocos de esos caseríos y sus territorios de influencia han sido reconocidos como comunidades campesinas, pero, según la fuente citada, podrían reclamar 16,3 millones de hectáreas, obviamente en su mayoría cubiertas por bosques de producción, especialmente bosques inundables. Parte de ellos ocupan, precisamente, las tierras ya deforestadas que se pretende, con esta nueva política, titular individualmente. Otra parte importante de sus tierras son las riberas de los ríos estacionalmente inundadas que tienen gran fertilidad (varzeas). Si se les reconociera como comunidades en ellos debería primar la misma política y los mismos apoyos técnicos, organizacionales y financieros que se aplican a las comunidades nativas.

\section{Mantener y aumentar los servicios ambien- tales}

En el futuro cercano la función primordial de los bosques y ecosistemas naturales debe ser la provisión de servicios ambientales. Este es un cambio fundamental con relación a todas las políticas y leyes precedentes. Claro que las leyes previas, como la que está vigente, declaran que su finalidad es "conservar y proteger el recurso" y "mejorar los servicios de los ecosistemas forestales y otros ecosistemas de vegetación silvestre...” pero, prácticamente todo en esas leyes y políticas, es utilitario, dedicado

\footnotetext{
${ }^{2}$ En el caso de los bosques secundarios provocados por acción humana será preciso decidir hasta qué edad serán considerados como tales antes de volver a tratarlos como bosques naturales climáxicos.
} 
a los productos del bosque, especialmente a la madera (Arce 2019). Los pocos textos dedicados a los servicios ambientales son siempre declarativos y subsidiarios a los que determinan la utilización maderera del bosque, y están especialmente basados en la teoría de que, si el aprovechamiento es sostenible, los servicios ecosistémicos están bien cuidados. Ocurre, como antes explicado, que esa sustentabilidad está fuertemente condicionada por la rentabilidad económica de la producción de madera y que raramente es alcanzada.

Por eso la política aquí propuesta, que refleja una tendencia mundial creciente (Fearnside 2008a, Martínez et al. 2018, Sist 2021), declara que "la función precipua del patrimonio forestal nacional es la generación de servicios ambientales o ecosistémicos" y que, consecuentemente, la producción de madera y de otros productos del bosque ya no es función primaria de los bosques naturales sino que es subsidiaria y aceptable sólo en la medida en que no afecte negativamente la provisión de esos servicios. Y eso sólo es posible si el manejo forestal que se aplica es de alta calidad y verdaderamente sostenible.

Las consecuencias de esta propuesta son muchas y se detallaran en los acápites subsiguientes. Entre ellas: (i) evitar la deforestación se torna absolutamente crucial y, por eso, se propone prohibir el cambio de uso de las tierras cubiertas de bosques y de otros ecosistemas naturales; (ii) se hace imprescindible lograr una mejora drástica de la calidad del manejo del bosque natural para alcanzar la sustentabilidad evitando la degradación del recurso y, para eso, habida cuenta de su limitada rentabilidad económica, es posible que ese rol deba ser en gran medida asumido por el Estado, lo que no ocurre actualmente; (iii) implica que las necesidades nacionales de madera deben provenir esencialmente de plantaciones, por lo que éstas deben ser fomentadas; (iv) implica asimismo valorar adecuadamente los tales servicios ambientales, reclamar el justiprecio y retribuir económicamente a los que cuidan del bosque permitiendo la generación de servicios ambientales, especialmente en términos de fija- ción o retención de carbono y mantenimiento del ciclo hidrológico. Estos aspectos se detallan en las secciones subsecuentes.

También se propone que los servicios ambientales sean internalizados en la economía nacional, efectivamente valorizados y valorados, debiéndose establecer mecanismos que remuneren o compensen efectiva y equitativamente a los que conservan los recursos naturales que proveen los servicios. Lograr esos objetivos será una tarea ardua que debe comenzar por la valorización de los servicios ecosistémicos y su inclusión tanto como tema transversal en la institucionalidad estatal como, especialmente, en las Cuentas Nacionales (MEF e INIE). Ya existiría una iniciativa del SERFOR y del INEI para implementar una cuenta satélite para medir el aporte del patrimonio forestal a la economía nacional, con asistencia de Costa Rica y Alemania (Andina 2020b). La internalización del patrimonio forestal nacional, como un todo, en las cuentas nacionales es asunto crucial (El Serafy y Lutz 1989, Meyer 1993) y debería ser adoptada sin dilación, como lo propuso Chávez (1995) para el Perú. Eso sería una revolución importante, pues con ello, la destrucción de bosques implicará una pérdida para todos los peruanos y no una ganancia, como se hace creer hasta el presente.

Es decir que el Estado se debe responsabilizar por el desarrollo y la aplicación de las normativas, mecanismos y acuerdos necesarios para las compensaciones o retribuciones a los conservadores del patrimonio forestal nacional o, en otras palabras, a los proveedores de servicios ambientales. También debe asociarse esos mecanismos a mercados para los servicios provenientes de ecosistemas forestales naturales o restaurados y a negocios integrados a cadenas de valor en base a los mismos. En la misma línea es necesario impulsar la comercialización nacional e internacional de servicios ecosistémicos (como bonos de captura de carbono, biodiversidad, captación de agua, así como valores escénicos y recreativos) y efectivizar arreglos internacionales que permitan pagar por fijación y no emisión de carbono (Pizarro 2021). 
Además, debe llevarse en cuenta que, pese a algunos progresos, la sociedad nacional aún vive muy ajena a la amenaza que el cambio climático y otros procesos en curso implican para su propio futuro (Bravo 2013, Ipsos 2020). Por eso la nueva política propone promover: (i) la concientización de la población sobre valores e importancia del patrimonio forestal nacional y sus servicios ecosistémicos para el devenir nacional; (ii) la incorporación de los mensajes sobre ecología, ambiente y servicios ecosistémicos, en especial de los bosques, en los currículos de educación a nivel escolar, tecnológico y universitario; (iii) informar adecuadamente a la sociedad nacional sobre los servicios ecosistémicos de los bosques y otros ecosistemas, brindándole acceso a información confiable, actualizada y relevante; (iv) programas educativos de largo plazo (nacional y regionales) de comunicación masiva a través de la radio, la televisión, Internet y las redes sociales más populares sobre los valores y beneficios del Patrimonio Forestal Nacional.

Conservar integralmente la diversidad biológica es otro aspecto clave de la política que se propone, ratificando y reforzando la copiosa legislación ambiental vigente. La supervivencia de numerosas especies nativas de plantas y animales, especialmente, las endémicas, está cada vez más amenazada, como lo demuestran las crecientes listas de especies amenazadas de plantas (MINAM 2018) y animales (SERFOR 2019). Lograrlo depende de tres grandes tipos de medidas: (i) las que aseguren que el aprovechamiento del patrimonio forestal nacional sea realmente sostenible; (ii) las que permitan restaurar las tierras y los ecosistemas degradados y; (iii) las que protegen muestras representativas de la naturaleza en su Estado más original posible. En las secciones previas se ha revisado los dos primeros tipos de medidas. En esta parte se discute, brevemente, la tercera opción.

Las Áreas Naturales Protegidas por el Estado o por el sector privado son la más antigua, más conocida y más eficaz forma de conservar la diversidad biológica de una nación ( $\mathrm{Mi}$ ller 1980, Bruner et al. 2001). El Perú, aunque comenzó tardíamente a hacerlo (Dourojeanni
2018), posee hoy un sistema de áreas naturales protegidas (nacionales y regionales) bastante completo (SERNANP 2021) y relativamente bien manejado. Este cubre 23,1 millones de hectáreas $(17,7 \%$ del territorio nacional), de las que 10,4 millones de hectáreas (45\%) son Parques Nacionales, casi todos cubiertos de bosques y todos, claro, de ecosistemas naturales. Las demás categorías de áreas protegidas, especialmente las Reservas Nacionales, tienen un grado de protección menor pero aun así se supone que cumplen sus funciones. Existen también 396000 ha incluidas en más de 150 reservas particulares. Es decir que la nueva política forestal en lo relativo a la conservación de la biodiversidad se asienta, primeramente, en los logros tan importantes ya alcanzados. Por eso propone: (i) respaldar la continuidad de la actuación del SERNANP y asegurar que las Áreas Naturales Protegidas disfruten de prioridad y de adecuado financiamiento; (ii) estimular el mejoramiento de la calidad del manejo de las áreas naturales protegidas públicas y privadas; (iii) completar o mejorar la representatividad ecológica del sistema mediante el establecimiento de nuevas áreas protegidas nacionales, regionales y privadas; (iv) estimular y apoyar a los municipios a establecer sus propias áreas naturales protegidas; (v) fomentar el establecimiento de concesiones de conservación y de ecoturismo mediante aprobación conjunta del SERFOR y del SERNANP; (vi) encargar al SERNANP la supervisión del manejo de las concesiones de conservación y de ecoturismo; (vii) promover que las nuevas áreas protegidas conformen corredores biológicos, con apoyo de la iniciativa privada, que asegure la preservación de las especies en función del cambio climático y; (viii) asegurar que los bosques de producción permanente, bosques de protección así como otros ecosistemas que forman parte del patrimonio nacional forestal sirvan efectivamente como partes esenciales de esos corredores.

\section{Enfrentar la deforestación}

Todas las naciones han deforestado para desarrollar su agricultura. Eso es un proceso normal. Pero tiene un límite a partir del 
cual se pierden los servicios ambientales del bosque y se perjudica a la misma agricultura y finalmente a la propia Nación. Como dicho, el Perú ya habría pasado o estaría muy cerca de ese límite. Algunos países, entre ellos varios europeos, exageraron y, por eso, pasaron a defender los bosques que quedaban y a replantarlos activamente hasta aproximarse al equilibrio necesario.

Por eso, se propone detener la deforestación en el país. Se demuestra que, cuando menos en el medio plazo, no es necesario eliminar bosques naturales para elevar considerablemente la producción agropecuaria en la región Selva. Y se insiste en que eso es posible, es decir viable social, económica y ambientalmente, si se toman medidas relativamente simples: (i) usar toda o la mayor parte de la extensión ya deforestada y servida por vías de comunicación que actualmente está subutilizada, abandonada o en "descanso" o degradada, regularizando la propiedad de la tierra y otorgando títulos sobre gran parte de la actualmente llamada "tierra de aptitud forestal"; (ii) aumentar la actualmente bajísima productividad agropecuaria mediante un eficiente servicio de asistencia técnica y financiera y; (iii) mejorar la vialidad y los servicios públicos en las áreas deforestadas en lugar de expandir carreteras en tierras cubiertas de bosques naturales. Complementariamente se debe (i) mejorar la capacidad institucional e incrementar la conciencia cívica para evitar la deforestación, (ii) eliminar las prácticas de extracción forestal que estimulan la deforestación; (iii) estimular la reforestación, las plantaciones forestales y el manejo de vegetación secundaria y, (iv) valorizar los servicios ambientales del bosque, remunerando a los que los generan o preservan.

Tomando como base los datos del IV Censo Agropecuario de 2012 (INEI 2012) interpretados por Zegarra y Gayoso (2015) y los ajustes posteriores (INEI 2018, 2020a) se sabe que el área "agrícola" de la Selva en 2019 alcanzaba 2888337 ha, de las que ese año se habrían aprovechado o cultivado efectivamente 1923 654 ha, de las que la mayor parte (1 580208 ha) estaban destinadas a cultivos permanentes, además de plantaciones forestales, mientras que 863395 ha estarían en descanso. Sabiendo, de otra parte, que ese año existían más de diez millones de hectáreas deforestadas, puede concluirse que no menos de ocho millones de hectáreas ya sin bosque no producían o no estaban siendo efectivamente usadas para actividades agropecuarias. En otras palabras, sólo se aprovechaba una de cada 5 hectáreas o solo el 19,4\% del área de bosques eliminados. Esta es la misma proporción constatada históricamente (Dourojeanni 1976, 2009b, 2019a). Gran parte de esa tierra sin uso o subutilizada está conformada por las llamadas tierras de aptitud forestal, sean de producción o de protección.

El cambio propuesto de la definición legal de patrimonio forestal nacional permitiría, pues, resolver el problema planteado por la existencia millones de hectáreas deforestadas o degradadas que están en cierta forma "congeladas" por ser consideradas tierras de aptitud forestal. Esa modificación permitiría entregar gran parte de ellas en propiedad privada o comunitaria para su aprovechamiento sostenible o restauración. Eso permitiría regularizar la tenencia de la tierra sobre millones de hectáreas deforestadas, aliviar tensiones sociales y estabilizar parte de los agricultores migrantes, permitir inversiones de medio y largo plazo y aumentar la producción agropecuaria y forestal. Mantenerlas, como ahora, en poder del Estado que no consigue protegerlas ni restaurarlas, no ofrece ventaja alguna, más aún dado el hecho de que, bajo las condiciones actuales, probablemente nunca recuperarían sus características originales.

Gran parte de los suelos de aptitud forestal, inclusive algunos de los llamados suelos de protección, pueden ser usados para fines agropecuarios, empleando tecnología disponible y con buen rendimiento, sin provocar mayores riesgos ambientales. Esas tierras poseen dueños informales, es decir posesionarios. $\mathrm{Al}$ recibir títulos de propiedad ellos podrán efectuar las mejoras necesarias en sus tierras y capitalizarlas. Buena parte se puede destinar a los tan necesarios programas de reforestación industrial o para diversas versiones de agrosilvi- 
cultura. Finalmente, debe tenerse presente que esta propuesta es parte de una estrategia mayor que incluye la prohibición del cambio de uso de la tierra cubierta de bosques naturales y la obligatoriedad de los propietarios de la tierra de preservar la vegetación cuya destrucción pondría en riesgo a otros pobladores y a sus propiedades. Es decir que el otorgamiento en propiedad debe ir de la mano con asistencia técnica y financiera y bajo la obligación de respetar algunas normas simples, como evitar el cultivo en pendientes excesivas o eliminar la vegetación ribereña.

¿Existen riesgos? Si. Es posible que esa medida acelere la deforestación tanto para asegurar recibir los títulos como para anticiparse a la prohibición de cambio de uso de la tierra de los bosques. También se especula que eso favorecerá a los que hicieron deforestación ilegal masiva en el pasado reciente (Che Piu y Galván 2015, Salazar y Rivadeneyra 2016) lo que, sin las debidas precauciones, probablemente se convierta en realidad. Sin embargo, debe aceptarse que en la tierra deforestada el daño ambiental ya está hecho y que este es irremediable. Hay diversas opciones para evitar o mitigar el riesgo de acelerar la deforestación durante el peligroso lapso previo a la plena operación de la nueva política. Una de ellas es titular únicamente las tierras en las que la posesión de la tierra ya tiene un cierto número de años o donde la deforestación ya tiene cierta edad. Otra es exigir la salvaguarda de las tierras frágiles (pendientes excesivas, vegetación ribereña, etc.) y su restauración cuándo es necesario o, en cambio, exigir que un porcentaje del área, especialmente la que aún tenga bosque, sea conservada y sometida a ordenamiento como reserva forestal, tal como leyes anteriores previeron, pero que nunca fue aplicado. Además, obviamente, no se titularían tierras que confrontan procesos legales o que están en litigio.

De otra parte, además de no usar la tierra disponible y habilitada para producción (desnudadas de árboles y en general servidas por carreteras), cada hectárea aprovechada produce significativamente menos, a veces varias veces menos de lo que podría si se aplicara en ellas las tecnologías disponibles (Huamanchumo 2013; MINAGRI 2016a, 2016b, 2017b, 2017c, 2017d, 2018). Un estudio brasileño en condiciones similares demostró que usando la mitad del área actualmente dedicada a pastos podría elevarse en $50 \%$ la producción de carne, liberando millones de hectáreas para uso agrícola, en lugar de deforestar (Strassburg et al. 2014). Esos hechos rebaten cualquier argumento de que hay que deforestar más para elevar la producción agropecuaria.

Pero frenar la deforestación, en general, requiere también de otras medidas que deben estar estrechamente asociadas: (i) establecer mecanismos de asistencia técnica y financiera que posibiliten elevar la producción sin expandir el área deforestada, es decir elevar la productividad; (ii) mejorar la calidad del sistema vial en las áreas ya deforestadas de modo a bajar los fletes; (iii) limitar la expansión vial que afecta bosques naturales e impedir la construcción de carreteras informales; (iv) reformar los planes de expansión de la producción agropecuaria concentrándolos en la elevación de la productividad y en el aprovechamiento de la tierra ya deforestada; (v) controlar efectivamente la minería ilegal; (vi) mejorar los servicios sociales (salud, educación, seguridad, comunicaciones) en las áreas ya deforestadas. Todas esas medidas son importantes pero el de las carreteras es estratégico. Y, evidentemente, es importante superar las visiones sectoriales e insistir en la gestión a nivel de paisajes (Sabogal 2018).

Esas medidas deben ser desarrolladas por los sectores agropecuario y transportes. Si no lo hicieran las probabilidades de éxito serían muy limitadas. Entregar tierras en propiedad a campesinos en su mayoría pobres sin asistencia técnica ni financiera y sin infraestructura de transportes realmente operativa no evitaría la deforestación. El tema de las carreteras es crucial, asimismo, para evitar que la expansión de la actividad agropecuaria atraviese la frontera forestal.

En efecto, es bien conocido que las carreteras son el principal vector de la deforestación (Alves 2001a, 2001b; Nepstad et al. 2001; 
Brandão y Souza 2006; Dourojeanni 2006; Laurance et al. 2009; Barber et al. 2014) y estas, en su mayor parte, son mal planeadas, atropellando otras iniciativas del Estado, por ejemplo, las áreas naturales protegidas, y no se someten a verdaderas evaluaciones de impacto ambiental y, en caso de hacerlas, éstas son tardías, mal consultadas y no aplicadas (Makki et al. 2001, Dourojeanni 2006, Vilela et al. 2020). Muchas de las carreteras oficiales no tienen vialidad económica (Fleck et al. 2010, Hopkins et al. 2015) y peor, la mayor parte de ellas, son decisiones locales completamente informales, sin estudios de ningún tipo que, lamentablemente terminan siendo reconocidas por el poder público (Mahar 1989, Dourojeanni 2013b).

Si lo anterior es realizado se logrará aplicar una de las principales propuestas de esta visión de política, es decir prohibir el cambio de uso de la tierra de los bosques y de otros ecosistemas naturales, estableciendo una frontera agropecuaria-forestal estable (Suárez 2021) o, dicho de otra forma, alcanzar la deforestación cero ya prometida por el gobierno peruano en 2008 por el entonces ministro Antonio Brack (Painter 2008).

\section{Evitar la degradación del bosque natural}

Como visto, la degradación del bosque ${ }^{3}$ es un problema menos visible pero tan importante como la deforestación. Compromete los servicios ambientales del bosque y reduce el potencial económico futuro de los bosques para su aprovechamiento maderable o de otros productos. Pero la principal causa de la degradación del bosque es, precisamente, el aprovechamiento forestal en la forma en que se realiza actualmente. Este problema, a diferencia del de la deforestación que depende más de los sectores agropecuarios, de transportes y minería, entre otros, es de responsabilidad directa del sector forestal que hasta el presente no ha conseguido imponer un nivel de manejo forestal adecuado y suficiente para garantir la sostenibilidad.
Los instrumentos disponibles para reducir la degradación forestal son de tres tipos: (i) los que simplemente prohíben total o parcialmente el uso consuntivo del bosque como en el caso de las áreas naturales protegidas, especialmente las de uso indirecto o parques nacionales; (ii) los que, permitiendo el aprovechamiento del recurso forestal, lo someten a modalidades de manejo de alta calidad y extrema precaución y; (iii) los que permiten restaurar o rehabilitar los ecosistemas que ya están degradados de modo a que vuelvan a brindar todos o parte de los servicios que naturalmente ofrecían.

Como previamente indicado, las áreas protegidas son administradas esencialmente por el Servicio Nacional de Áreas Naturales Protegidas por el Estado (SERNANP) que depende del sector ambiente. El territorio cubierto por esas áreas es muy significativo (SERNANP 2021). Aunque no toda esa área está adecuadamente protegida y que contra ellas existen amenazas bien conocidas (MINAM 2016b, Ráez 2016), puede asumirse que esos espacios continuarán brindando servicios ambientales. El tema de la restauración de ecosistemas degradados se trata en otra sección. Por tanto, en esta sólo se discute el tema del aprovechamiento forestal de los recursos.

Lo que se propone para evitar la degradación de los bosques, es decir manejándolos conforme a los principios de la sostenibilidad, se fundamenta en la devolución al Estado de la responsabilidad principal del manejo de los bosques naturales para producción de madera y otros productos del bosque. Como visto, desde hace varias décadas el manejo forestal recae directa y exclusivamente sobre los que aprovechan los recursos forestales, correspondiendo al Estado apenas la fiscalización. Las últimas opciones de manejo de los bosques naturales directamente por el Estado fueron cortadas con la ley 27308 del año 2000, que eliminó los últimos bosques nacionales, que en realidad ya habían sido abandonados desde más de una década antes (Dourojeanni 2009b).

\footnotetext{
${ }^{1}$ Preciso es reiterar que en este caso se trata de degradación del bosque natural o del ecosistema y no de la degradación de la tierra, cuya expresión más obvia es la erosión del suelo. Obviamente, la degradación del bosque suele ser un paso en dirección a la segunda y no existe un límite preciso entre ellas.
} 
Como ha sido explicado, no existe manejo forestal en las explotaciones forestales informales, incluyendo la que se practican en bosques de comunidades nativas, bosques comunales o en propiedades, en las que se hace desbosque. En estos bosques, que proveen la mayor parte de la producción maderera nacional, se practica el descremado con todas las graves consecuencias ambientales bien conocidas en el Perú y demostradas en toda la Amazonía (Arima et al. 2005, Souza y Roberts 2005, Peres et al. 2006). Pero, como también evidenciado, salvo pocas excepciones y quizá levemente atenuado, sucede lo mismo en la enorme mayoría de las concesiones forestales otorgadas con las últimas dos leyes forestales (Kometter 2016, 2019; Tuss de Orbegoso 2017; Dourojeanni 2020) quedando demostrado que esas deficiencias son tanto o más de la legislación vigente, que entre otros defectos permite rotaciones extremamente cortas, que de la actuación de los propios concesionarios. Ocurre, en realidad, que éstos últimos están arrinconados entre las costosas exigencias de un manejo verdaderamente sostenible, la abrumadora competencia desleal de la informalidad y, de otra parte, la falta de apoyo técnico y financiero del Estado agravada por sus excesos fiscalizadores y burocráticos. En resumen, el sector privado no puede, en las condiciones actuales, practicar manejo forestal realmente sostenible que, a la vez, sea rentable (Louman y Stolan 2002, Colán et al. 2006, Smith et al. 2006, Mejía et al. 2015, Dourojeanni 2020). Pero también se ha demostrado que el precio de la madera en pie cobrado por el Estado es mal negocio para este (Giudice et al. 2012). En conclusión, pese a que existen desde hace cinco décadas, los contratos y concesiones forestales, no han resuelto ninguno de los problemas de la extracción forestal en el Perú, ni han aumentado la producción, estando la mitad de las concesiones otorgadas actualmente abandonadas o han sido caducadas.

Por eso, se propone devolver al Estado su rol fundamental relativo al manejo de los bosques naturales. Como se verá, la propuesta no pretende crear una empresa forestal del Estado ni realizar directamente labores de extracción, silvicultura, industrialización o comercialización. Todas esas actividades quedarán, como actualmente, en manos del sector privado o del comunitario. Pero corresponderá al Estado, a través de sus instancias técnicas, diseñar el plan de manejo de los bosques de producción de su jurisdicción, aplicarlos y supervisar su cumplimiento. Esa medida se justifica porque, considerando que el rol precipuo de estos bosques es la provisión de servicios ambientales esenciales para la sociedad, es insensato cargar los costos del manejo requerido al sector privado. Este aprovecha los bosques mediante operaciones comerciales de producción de madera y no recibe retribución por la generación de servicios ecosistémicos.

La dificultad de extraer madera de los complejísimos ecosistemas forestales tropicales sin afectar sus mecanismos ecológicos ni disminuir sus beneficios ambientales es tan grande (ITTO 2016) que sus costos no pueden ser compensados por el valor que actualmente tiene la madera, por preciosa y demandada que sea. Y a eso hay que sumar, como se ha dicho, la realidad impuesta por la competencia desleal de la informalidad y el impacto de la corrupción que domina el sector. Por lo tanto, lo más razonable es que sea el propio Estado, su servicio forestal nacional y regional, que decida el manejo, ofreciendo a los industriales y comerciante el volumen de madera recomendado anualmente por el plan de manejo elaborado técnicamente, usando las mejores evidencias científicas disponibles. En la práctica, el sector privado continuará siendo el que extraiga, procese y comercialice la madera. El Estado solamente va a administrar el bosque de cerca, es decir planear el uso del recurso forestal en la jurisdicción mediante la preparación de los planes de manejo, su aplicación en los bosques manejados y la supervisión de la extracción.

¿Es realista asumir que el Estado puede realizar el manejo forestal sostenible que las empresas no logran? Esa modalidad de manejo de los bosques naturales es practicada en los bosques públicos de varios países desarrollados y lo fue, asimismo, brevemente, en el Perú es- 
pecialmente en los bosques nacionales Iparía y von Humboldt, en los que fracasó por razones y en un contexto político completamente diferente al que está ahora en debate (Dourojeanni 2009b, 2017). En el primer caso de Iparía, el Estado manejaba y explotaba directamente el bosque, contando con maquinaria de extracción moderna y un aserrado modelo. Eso fracasó debido a la inoperancia del Estado para realizar directamente operaciones comerciales. Por eso, esa no es la propuesta que aquí se hace. En el segundo caso de von Humboldt, se aplicó un modelo diferente, reservando el manejo para el Estado y dejando la extracción al sector privado. En este caso el fracaso fue principalmente consecuencia de la invasión del bosque provocada por la intervención de otros sectores públicos. No obstante, en ambos casos, los profesionales nacionales fueron capaces de planear y conducir bien las operaciones mientras duraron. Los mismos profesionales que actualmente hacen los planes de manejo para las empresas y los que los aprueban y supervisan desde el SERFOR, el OSINFOR y las administraciones forestales regionales, serán los que hagan los planes de manejo para los bosques de producción de cada circunscripción (cantón o distrito forestal) y que supervisarán su aplicación, bien sea como funcionarios públicos o como consultores para el Estado. Subastas anuales de madera permitirán el ingreso al bosque de extractores para retirar ejemplares $\mathrm{y}$ volúmenes de individuos previamente marcados, respetando normas preestablecidas de extracción de bajo impacto. Puede alegarse, también, que tal situación incrementaría la corrupción ya instalada en el sector público. Pero toda la actividad económica de las autoridades forestales encargadas del manejo sería regida y supervisada por consejos locales de gestión forestal en la que participan todas las partes involucradas (madereros, industriales, comunidades indígenas o campesinas, academia, organizaciones no gubernamentales, otras entidades públicas regionales y locales). En esas condiciones serían demasiadas las partes con intereses encontrados que deberían estar de acuerdo en ejecutar o respaldar actos ilegales.
Es importante señalar que la propuesta no incluye eliminar las concesiones forestales vigentes que, mientras continúen cumpliendo las normas serían respetadas y respaldadas, las cuales, si en el transcurso del tiempo operan bien, podrían ser renovadas. Es más, se insistirá en que todas ellas tengan certificaciones forestales prestigiosas (Arce 2000) y, en la medida de lo posible, que estén asociadas a programas de tipo REDD Plus, entre otros. También se aplicarían, en la medida en que se viabilicen, técnicas de trazabilidad, las que ya se usan en forma limitada (Navarro 2014). Lo mismo sería válido para los bosques de las comunidades nativas que se pretende sean bien manejados por ellas mismas, con asistencia técnica del distrito forestal respectivo o en cooperación con empresas.

¿Qué ventajas ofrece el manejo de los bosques de producción directamente por el Estado? Lo que a primera vista puede parecer contrario a los intereses de los industriales madereros y pequeños extractores ofrece, en realidad, una alternativa favorable para su situación actual. Ellos pueden aplicar a las subastas anuales, con proporciones previstas para las diferentes categorías, y comprar el volumen de madera de las especies que se ofertan, sin tener que pleitear concesiones o autorizaciones de todo tipo. No deberán enfrentar la burocracia ni preocuparse de gastos en inventarios, planes de manejo, vigilancia y protección de los bosques concesionados, ni tendrán que aplicar programas silviculturales, preparar engorrosos informes o atender las visitas de supervisión del OSINFOR o de otras agencias públicas. De otro lado, el manejo forestal conducido directamente por el Estado no tiene el lucro como finalidad. Su objetivo es la conservación del recurso, sin desmedro de mantener activa la producción maderera, las oportunidades de empleo y la economía local. El precio al que se subaste la madera debe ser suficiente para cubrir los costos del manejo, pero no tiene la obligación de generar ganancias o utilidades. Los derechos forestales deberán ser establecidos en función del valor de la especie maderable, calculado sobre la base del precio de mercado para evitar 
la sobrecarga extractiva en pocas especies y de modo a regular la extracción. También se prevé una campaña para dar o devolver a la madera natural su justo valor y adecuada apreciación en el mercado nacional e internacional (Dancé 2006), donde los volúmenes podrán ser menores pero el precio mucho mayor.

Finalmente, debe llevarse en cuenta que el manejo de los bosques a cargo del Estado no es una medida aislada. Ella se dará en el contexto de una prohibición de cambio de uso de la tierra cubierta de bosques, facilitando mucho el control de la producción y tránsito de la madera ilegal y estará acompañada de un esfuerzo de reforestación y manejo de bosques secundarios sin precedentes, además de nuevas oportunidades en la actividad agropecuaria y agroforestal, que debería atender en mucho las perspectivas económicas de los pequeños extractores cuyas actividades son diversificadas.

El caso de los pequeños extractores debe ser abordado en forma especial ya que, ellos han sido y son los principales motores de la degradación del bosque y los más difíciles de controlar tanto por su elevado número, como por sus expectativas socioeconómicas actualmente muy insatisfechas. Estos son en gran parte pobladores ribereños que, por lo tanto, no se van a beneficiar de la entrega de las tierras de aptitud forestal que se encuentran en su mayor parte localizadas en la Selva Alta. Para ellos se prevé tres medidas claves: (i) mejorar las modalidades de acceso a los bosques públicos; (ii) desarrollar programas de organización empresarial, capacitación y asistencia técnica y financiera y; (iii) otorgarles derechos sobre las tierras que usan tradicionalmente (como visto en otros acápites).

Es verdad que en todas las políticas previas como en la actual existió la intención de dar un trato y acceso especial al bosque a los pequeños extractores. Pero en todos esos casos se les otorgaban áreas de bosque (contratos de hasta mil hectáreas, concesiones de "reforestación", bosques comunales) que ellos deberían manejar y cuidar lo que obviamente nunca hicieron ni podrían haber hecho. En este caso, previo su registro y concomitantemente a su organización empresarial se les otorga la opción de extraer el volumen y las especies que el plan de manejo reserva para ellos, sin conflicto con las grandes empresas, que operan en concesiones o las medianas que tendrán otras opciones de extracción en los bosques manejados por el Estado de la localidad. Los pequeños extractores solamente deberán cortar y retirar los árboles autorizados, cumpliendo las instrucciones. Pero, como parte de la estrategia está hacerlos progresivamente cada vez menos dependientes de la extracción de madera del bosque natural y más de las plantaciones forestales y de las actividades de agroforestales en sus chacras.

No todos los bosques amazónicos son iguales. Algunos requieren de manejo especial o especialmente cuidadoso. Tal es el caso de los bosques inundables (tahuampales), tan importantes para la vida de los pobladores ribereños, mestizos o indígenas de la Selva Baja como para la biología de innumerables especies valiosas de la fauna y de la flora. Es, asimismo, el caso de los bosques sobre las turberas (especialmente los aguajales), que están en gran parte localizados en Loreto, pero que ocurren en toda la Selva Baja. Esos bosques hidromórficos cubren 7,5 millones de hectáreas. Su mal uso podría liberar enormes volúmenes de carbono. (López et al. 2020). También debe mencionarse el caso de los varíllales de esa misma región. Esta política prestará atención diferenciada a esos bosques, entre otros, aplicando los mejores conocimientos científicos disponibles.

\section{Rehabilitar las tierras degradadas}

Atenuar o reducir la degradación de tierras tiene un impacto importante en evitar la reducción de la superficie apta para la producción agrícola, que afecta la seguridad alimentaria y crea la necesidad de ampliación de la frontera agrícola, con lo que se estimula más la deforestación. Combatir la degradación de tierras tiene, asimismo, un impacto directo y positivo sobre la mitigación de impactos del cambio climático, la generación de empleos e ingresos, el aumento de opciones para mejorar la calidad de vida de la población, así como para crear una 
mayor resiliencia o capacidad de recuperación de los ecosistemas y, a la vez, evitar que nuevas áreas se deterioren o degraden.

Obviamente, para desarrollar un programa nacional de restauración es estratégico articular y coordinar esfuerzos de una manera multisectorial y en los tres niveles de gobierno. Todos son importantes pero el nivel local es crucial. Para esto, se debe: (i) establecer plataformas intermunicipales e interregionales (mancomunales) para abordar problemáticas comunes específicos como la tala de los bosques secos en el norte o la quema o destrucción de bofedales andinos; (ii) suscribir compromisos (a través de ordenanzas) de los gobiernos regionales y municipales para incorporar la restauración en la planificación concertada regional y municipal en sus correspondientes procesos de elaboración del presupuesto participativo y en las prioridades de sus presupuestos regulares; (iii) generar alianzas con organizaciones rurales (comunidades, asociaciones, comités de productores, juntas de regantes, entre otros, para comprometerlos y actuar conjuntamente en la implementación de la restauración y; (iv) acompañar y dar asistencia técnica y social a los gobiernos regionales y municipales para la formulación, seguimiento y evaluación de programas y proyectos de restauración.

Al nivel nacional es preciso: (i) definir normas y procedimientos para que el Ministerio de Economía y Finanzas y los demás sectores competentes consideren la restauración como componente vinculante en la aprobación de programas y proyectos, así como se incorpore en los programas de estímulos municipales; (ii) establecer mecanismos de financiamiento, así como de incentivos económicos y fiscales que faciliten las actividades de restauración o la retribución por servicios ecosistémicos; (iii) identificar y gestionar canales innovadores de financiamiento y cooperación (fondos fiduciarios, fondos de apoyo social empresarial, eco-negocios, impuestos por obras, servicios ambientales, REDD+ y microfinanzas entre otros) para la implementación del propuesto programa nacional de restauración; (iv) revisar y adecuar las actuales políticas, normas y pro- gramas de carácter nacional, regional y local en su relación con la situación de la restauración, incluyendo propuestas que permitan aplicar medidas preventivas y correctivas, así como de incentivos y; (v) institucionalizar la enseñanza sobre restauración en los centros educativos superiores en la formación de grado y posgrado, incluyendo planes de desarrollo de capacidades relacionados con la gestión pública (carrera del servidor público).

Otro tema de degradación de tierras se refiere a la responsabilidad directa del dueño o usuario de esta, tanto en evitar degradación como en remediarla. El Estado debe estimular y apoyar, de modo efectivo, a los campesinos en la tarea de restaurar ecosistemas degradados, pero no debe tolerar que los mismos continúen degradando el recurso, en especial poniendo en riesgo físico a los demás o comprometiendo la calidad y la disponibilidad del agua. La legislación nacional ha sido ineficaz para evitar esos comportamientos, aunque sea obvio que gran parte de los huaicos y aluviones, así como la mala calidad del agua tienen responsables identificables. En general se identifican las operaciones mineras legales o ilegales, pero se soslaya la responsabilidad directa de miles de agricultores que desnudan laderas con pendientes inviables para la siembra o que cortan toda la vegetación en la ribera de cursos de agua o de los ganaderos que queman enormes áreas de pastos naturales en los Andes, deteriorando el ecosistema y contribuyendo al cambio climático. Otro tanto es el caso de los agricultores que en condiciones de Selva y de Costa "queman" los residuos de las cosechas o los provenientes de la preparación del terreno, muchas veces provocando incendios de grandes proporciones.

El establecimiento de bosques que técnicamente son de protección como Âreas Naturales Protegidas (SERNANP) o como bosques protectores (SERFOR) es útil cuando se detectan grandes áreas que necesitan ese tipo de salvaguarda. Pero su gestión es costosa y subsiste el hecho de que dentro de ellas existen bolsones de tierra con potencial agropecuario o forestal, creándose mucha confusión. Por eso 
se propone adoptar la política de que la primera responsabilidad de cuidar de esas áreas, sean grandes o muy pequeñas, sea directamente del dueño o posesionario de la tierra que, de no hacerlo, debe ser sancionado. En efecto, las tierras susceptibles de degradación están estrechamente imbricadas en cualquier lugar o propiedad y ningún Estado tiene capacidad para ocuparse de eso. Se propondrá una ley, basada en principios generales de uso de la tierra, que defina esa responsabilidad, sus alcances, límites y consecuencias para quien la incumpla. Este tipo de leyes existe en muchos países, por ejemplo, en el Brasil, y su cumplimiento es bastante efectivo, mediando alicientes y sanciones. Es decir que gran parte de la responsabilidad de evitar y de subsanar la degradación de las tierras debe recaer, por el solo efecto de la ley, en los propietarios o responsables por esa tierra.

Habiendo tierras degradadas en las propiedades rurales es crucial ofrecer alternativas económicas que permitan obtener una renta adecuada a la par que evitar que continúe la degradación de la tierra. Una de las alternativas disponibles es la gestión de sistemas agroforestales y el uso sostenible de los remanentes de los ecosistemas forestales existentes en sus propiedades. Los sistemas agroforestales se definen como sistemas productivos en los que se mantiene o, mejor, se aumenta la proporción de árboles y no al contrario, como suele ocurrir (Dourojeanni 2009a, Putzel et al. 2012). De otra parte, pueden ser fuente importante de ingresos en la economía rural familiar y, al mismo tiempo, contribuyen a la adaptación al cambio climático y a la conservación de la biodiversidad (FAO 2015) y tienen una larga tradición en el Perú, en sus tres regiones naturales, pero especialmente en la Selva (Meza y Cornelius 2006). Su importancia para mitigar los impactos del cambio climático ha sido resaltada en el contexto peruano (Alegre y La Torre 2012). Por eso, en esta política: (i) se promueven paquetes $\mathrm{y}$ alternativas financieras y tecnológicas para el desarrollo e implementación de los sistemas agroforestales con asistencia técnica y financiera, con apoyo del Estado; (ii) se establece y opera un fondo para pagos por servicios ecosistémicos al que puedan acceder los titulares de predios privados para financiar un conjunto de opciones y técnicas sostenibles de uso de la tierra que favorezcan la biodiversidad, la conservación de suelos y aguas, la captura de carbono y el enfoque de paisaje, y promueva el uso de especies nativas de manera preferente y; (iii) se fomentan las transacciones de intercambio comercial de los bienes y servicios producidos por el manejo y conservación de los bosques y otros ecosistemas de vegetación silvestre que se encuentren en los predios privados titulados.

La nueva política llevará en serio el tema de los incendios forestales que, en función del cambio climático es crecientemente preocupante tanto en Costa y Sierra, inclusive en plantaciones forestales, como en la Selva, donde desde hace dos décadas se evidencian con más frecuencia fuegos en el bosque que, si bien se inician con los focos de calor originados por los campesinos, se propagan cada vez más profundamente dentro del bosque degradado (da Silva et al. 2018). Por eso se prevé la creación de un cuerpo de bomberos forestales (Dourojeanni 2016), quizá como parte de la formación de guardabosques y el fortalecimiento de la capacidad de respuesta de las autoridades forestales regionales.

\section{Para aprovechar y cuidar de la fauna silvestre}

La fauna silvestre ha sido históricamente despreciada dentro de la administración pública peruana (Dourojeanni 2009b). Y, curiosamente, eso no corresponde a su importancia relativa para el bienestar de la población amazónica ni tampoco a su aporte a la economía. En efecto, como es bien conocido, la fauna silvestre ha sido y aún es parte considerable de la dieta de los pobladores rurales amazónicos (Pierret y Dourojeanni 1966, 1967; Aquino y Calle 2003; Peres y Palacios 2007; Constantino et al. 2008; Parry et al. 2014) y, durante largos periodos ha aportado más al PBI que la propia madera (exportación de pieles y cueros, animales vivos, valorización de la carne de monte, lana, ejemplares para experimentación, cochinilla), pese a que su contabilización siempre ha sido minimizada (Dourojeanni 1972). Ese maltrato burocrático apenas ha sido menor con las aves guaneras y con la vicuña (Dourojeanni 
1986b), que han merecido alguna prioridad. Pero excepto brevemente en los años 1970 (programas nacionales de vicuña y de primates no humanos), todas las demás especies, siendo o no importantes para la alimentación, la salud y/o la economía, nunca fueron objeto de proyectos o inversiones públicas siquiera comparables a los que se dedicaron a la producción de madera. Y, en lo que respecta a la fauna en su conjunto, como elemento de la diversidad biológica, la atención ha sido aún menor, pese a que ha mejorado en la última década en que los científicos y las organizaciones sociales han demandado una actitud un poco más proactiva del Estado.

La fauna silvestre nunca ha recibido más que unos cuántos artículos en un capítulo aislado dentro de las legislaciones forestales y, durante décadas su gestión estuvo a cargo de una subdirección dentro de otras direcciones de la autoridad forestal, es decir sometida a un tercer o cuarto escalón de la jerarquía ministerial, sin acceso a discusiones sobre presupuesto $\mathrm{u}$ otras importantes. Esa era la situación, asimismo, de las áreas naturales protegidas que solo prosperaron cuando comenzaron a ganar independencia, siendo evidente el gran salto adelante dado al ser creado el SERNANP.

En la actualidad hay problemas gravísimos relacionados a la fauna silvestre que, por las razones expuestas, no son abordados con la atención que merecen, siendo subordinados a temas agrarios o forestales $y$, lo peor, es que se están perdiendo muchas oportunidades de incorporar más especies a la economía nacional sin ponerlas en riesgo, como en el caso del avistamiento de aves, insectos, etc. En la actualidad, es preocupante el comercio de carne de monte (Parry et al. 2014, van Vliet et al. 2014). Además, existe un recrudecimiento del tráfico de animales vivos (Sinovas et al. 2017) frecuentemente asociado al narcotráfico. El caso de la demanda china por grandes felinos, especialmente el jaguar, es digno de medidas concretas urgentes (Morcatty et al. 2020). Además, por esa inacción, el Perú incumple sus compromisos internacionales. También es necesario dar más atención a los problemas recurrentes de la introducción de especies exóticas dañinas a los ecosistemas naturales o a la agricultura.

En 2018 se publicó la última versión del Libro Rojo de la Fauna Silvestre Amenazada del Perú que muestra un notorio incremento de animales amenazados en el Perú. En ella se incluyen 535 especies, de las que 63 están en peligro crítico e inminente de extinción y, de estas, 33 son anfibios (SERFOR 2018). Los anfibios, como se sabe, son indicadores valiosos de la calidad del ambiente por ser muy sensibles a los cambios. El aumento del número de especies en la lista responde, como es evidente, a la expansión de la ocupación de los ecosistemas naturales, pero, asimismo, al mejor conocimiento que se está adquiriendo sobre la biota peruana. Esta, de otra parte, se caracteriza por un elevado número de endemismos, lo que aumenta su fragilidad. Bajo cualquier criterio, las listas rojas de plantas y animales son una alerta importante sobre la gravedad de la situación del patrimonio natural peruano. Además, habría que tener en cuenta que esas listas, a pesar de exhibir números abultados y crecientes, son muy incompletas.

Ha sido común considerar que la fauna silvestre está adecuadamente protegida en las Áreas Naturales Protegidas. Pero eso no es completamente verdad debido a que no todas las especies ni sus poblaciones están incluidas en el Sistema Nacional de Áreas Naturales Protegidas (SINANPE) y al impacto creciente del cambio climático que las obliga a movilizarse. Muchas especies requieren de proyectos especiales y de recursos un poco más generosos para garantizar su sobrevivencia y su aprovechamiento futuro. Por eso se propone que se adopte, como en la mayor parte de los países del mundo, una legislación ad hoc para la fauna silvestre y, también, la creación de un servicio independiente para su aplicación, al mismo nivel que el SERFOR y el SERNANP con sus réplicas a nivel regional.

\section{Plantar bosques y aumentar la producción forestal}

Aunque el bosque natural seguirá produciendo madera es evidente que, pasando a ser su 
primera función proveer servicios ambientales, esa producción, probablemente será menor y que por tanto deberá ser complementada. Es pues preciso atender la grande y creciente demanda de madera, especialmente la de tipo industrial que, progresivamente, deberá convertirse en el principal motor de la industria forestal. De hecho, el Perú cuenta con las tierras, los recursos genéticos y los climas apropiados para implantar varios tipos de producción de madera con muy diversas especies nativas o exóticas.

La importancia de las plantaciones forestales $^{4}$ en el Perú es realzada por varios hechos. En efecto, la mayor parte de los árboles de bosques naturales, sean tropicales húmedos o secos, así como altoandinos, crece muy lentamente, siendo su madera por ello bella y valiosa. Y por eso debería tener un mercado nacional e internacional sofisticado, para diferentes usos industriales, incluido su uso en la mueblería fina y similares. En cambio, la madera industrial de uso común o madera de obra debe provenir, como en todo el mundo, de plantaciones con árboles de rápido crecimiento. De otra parte, aunque las plantaciones forestales industriales no tengan como finalidad brindar servicios ecosistémicos, no dejan de proveerlos en mayor o menor grado dependiendo del tipo de plantación y su manejo. En efecto, las plantaciones forestales contribuyen a mejorar el ciclo hidrológico, a conservar los suelos y fijan carbono mientras crecen y lo mantienen fijado en muchos de los usos sucesivos de su madera (Binkley 1999, Rodríguez et al. 2014, Domke et al. 2020). Pero los dos argumentos más importantes para plantar bosques son que se trata de una actividad económica altamente rentable que, además, provee empleos de calidad en lugares donde no hay muchas otras alternativas y que tiene amplio espacio disponible, actualmente desperdiciado o subutilizado, en las tres regiones naturales del Perú.

Las políticas previas no consiguieron expandir las plantaciones de modo significativo, especialmente las industriales. Además, están dispersas y sólo tienen transcendencia regional. Esas plantaciones son de baja a muy baja productividad resultado de un deficiente manejo silvicultural, del uso de semillas de baja calidad genética, de la escasa aplicación de técnicas de mejoramiento de suelos y de la falta de criterios sólidos para la selección de sitios. Algunos estimados de incrementos medios anuales de plantaciones varían entre 5 y $7 \mathrm{~m}^{3} / \mathrm{ha} /$ año en Sierra y 15 y $20 \mathrm{~m}^{3} / \mathrm{ha} /$ año en Selva. Pero hay evidencias de estos rendimientos pueden ser triplicados (Fundación Backus 2015, Guariguata et al. 2017). Varios autores, entre ellos los mencionados han hecho propuestas concretas para impulsar la reforestación, insistiendo en su promoción desde las regiones, la preparación de proyectos modelos más ambiciosos y, en especial, el acopio y la disponibilidad de información de calidad sobre las alternativas, basadas en investigación científica. Esto es particularmente importante para una actividad que madura en plazos relativamente largos, con inversiones iniciales considerables. $\mathrm{Y}$ se cita, asimismo un mejor conocimiento del mercado a lo largo de la cadena de valor, incluyendo inversionistas potenciales tanto nacionales como internacionales además de los gobiernos regionales. El Estado debe fomentar y facilitar la instalación de industrias forestales que consuman madera de plantaciones, como los tableros y, cuando la oferta de la madera sea mayor, el de celulosa. Por ese motivo, apenas en la última década, se presentaron dos proyectos de ley (Proyecto de Ley 2550/2017, Proyecto de Ley 07501/2021) para brindar a la reforestación la posibilidad de desarrollo. Las propuestas proponían la creación de un fondo y de una mesa forestal regional. El proyecto de ley actual tiene propuestas económicas mucho más completas e interesantes.

Las plantaciones forestales pueden revestir diferentes modalidades: (i) industrial o comercial convencional, (ii) ser parte del paisaje rural o, (iii) ser parte de programas de restauración,

\footnotetext{
${ }^{1}$ Es tradicional, en el país, hablar de "reforestación" para expresar plantaciones forestales. En realidad, no es lo mismo. Se reforesta donde hubo deforestación, lo que no siempre es el caso de las plantaciones. A veces, para ese último caso se usa el término "forestación". El término adecuado y que se usa en este texto es, en todos los casos, plantaciones forestales.
} 
recuperación y rehabilitación de ecosistemas degradados. Otras opciones incluyen las plantaciones de enriquecimiento, que se practican en bosques manejados y que pueden ser consideradas parte del manejo forestal de bosques naturales y, aunque no sean propiamente casos de plantaciones forestales, también el manejo de la regeneración natural que se practica a nivel de las chacras. Las plantaciones forestales y las demás opciones silviculturales deberán, lógicamente, desarrollarse en armonía y complementariedad con otros sistemas productivos, incluida la agroforestería. Todas las modalidades son importantes y todas deben recibir apoyo por igual. Pero las opciones de apoyo y financiamiento no son las mismas en cada caso.

El potencial para plantaciones está especialmente concentrado en la Sierra y en la Selva, pero no es despreciable en la Costa, donde debe poder competir con cultivos más intensivos, pero no necesariamente más rentables. Además, las aguas servidas tratadas son una fuente de agua para la forestación, a bajo costo y con impacto ambiental positivo. Existen 7 000 ha de tara en Costa y Sierra con rendimientos y rentabilidad aceptables (Barriga 2012). En la Sierra el área disponible para plantar bosques artificiales está muy concentrada en tierras de comunidades campesinas. De hecho, las comunidades campesinas poseen la mayor parte de la superficie agropecuaria del país (del Castillo 2014), siendo pues, piezas claves para la expansión de las plantaciones. Gran parte de esa tierra está sin bosque y es dedicada a pastoreo extensivo de baja rentabilidad que podría ventajosamente ser transformada a cultivos forestales o a prácticas silvopastoriles. Los comuneros andinos llevan décadas practicando una silvicultura de baja calidad, pero han desarrollado mucha afinidad y disposición al tema, como se ha demostrado en Cusco y Cajamarca, entre otros lugares (Kenny-Jordan et al. 1999, Dourojeanni 2009b, Guariguata et al. 2017, Carton y Chávez 2018).

Para efectos de esta propuesta se considera que todas las especies, nativas y exóticas, tienen su lugar y vocación en el enorme y variado espacio ecológicamente disponible para plantar árboles. No cabe perder oportunidades de desarrollo importantes por prejuicios infundados contra especies como pino y eucalipto que, en Chile y Brasil, son los motores de la forestería económica. Como reiteradamente se ha demostrado los voceados impactos negativos de esas especies son consecuencia de deficiencias en la elección del sitio y en el manejo de las plantaciones (FAO 2009, 2021a; Prado 2019). Pero es evidente que, especialmente en la Selva, existen numerosas especies nativas que cuando son debidamente domesticadas y seleccionadas pueden competir ventajosamente con las exóticas (Flores 2012, Ugarte-Guerra y RománDañobeytia 2020). Es indispensable, asimismo, dar más atención y prioridad al cultivo de bambú, cuyo potencial es reconocidamente enorme como materia prima para industrias (MINAGRI 2010a) y del que ya existen varias plantaciones. Finalmente, debe llevarse en cuenta que no se usan las mismas especies para cada tipo de reforestación, siendo obvio que para casos de restauración o rehabilitación de ecosistemas degradados deben usarse las especies nativas propias del lugar, salvo que otras se usen como tutores o nodrizas para ser eliminadas posteriormente.

Se reitera la importancia de que las plantaciones forestales dispongan de una legislación propia, que realmente atienda sus realidades que, además, son muy diferentes en cada región del país. Como ya ha sido parcialmente aplicado (ver el artículo 6o del Reglamento de la Gestión de Plantaciones Forestales y Sistemas Forestales vigente) las plantaciones forestales deben ser consideradas como cultivos, pudiendo establecerse en cualquier suelo y no restringirlas solo a los "aptitud forestal". La silvicultura solo se diferencia de la agricultura por el lapso del ciclo de producción, aunque muchos cultivos, frutales entre otros, ocupan el suelo por más tiempo que un bosque cultivado. Las plantaciones forestales deben pues, beneficiarse de los mismos privilegios que la agricultura, sector del cual debería depender. Existe, claro, una zona de sobreposición entre sectores en lo que se refiere a plantaciones de restauración, rehabilitación o recuperación y, asimismo, con 
el manejo de vegetación secundaria, aunque todas ellas están más ligadas a la agricultura que al manejo del bosque natural.

En resumen, se propone adoptar las siguientes medidas que, en su mayor parte, nunca estuvieron disponibles, menos aún todas juntas. De una parte, gracias a las medidas ya comentadas sobre las tierras de aptitud forestal, existirá una mayor disponibilidad de tierras con seguridad jurídica en la Selva para posibilitar la inversión privada, que debería ser el motor de la silvicultura industrial. Las propiedades, es decir la tierra y el vuelo o estoque forestal constituirían garantía inmobiliaria. De otra parte, se crearían líneas de crédito de bajo costo provistas tanto por el sistema financiero público como por el privado; o se estimularían la inversión de largo plazo por el Estado como es y fue en otros países de la región. Pero, además, se establecería un estímulo adicional mediante un cierto nivel de cofinanciamiento estatal para los primeros años de instalación de plantaciones forestales comerciales en tierras de comunidades campesinas y nativas en las que se concentrará la asistencia tanto para las plantaciones como para la gestión empresarial. Asimismo, se incluiría la aplicación de un seguro de siniestros en plantaciones forestales por incendios, sequías, inundaciones, plagas y otros perjuicios imprevisibles o incontrolables.

Para suplir las deficiencias técnicas actuales se crearía un sistema integrado de bancos de germoplasma que aseguren la calidad de la semilla y su adecuación a cada región ecológica. Esto, lógicamente, estaría acompañado de un centro de información tecnológica silvicultural para brindar asistencia a los productores, basado en un esfuerzo especial para implementar un programa nacional de investigación y desarrollo de plantaciones forestales que responda real y efectivamente a las necesidades de los plantadores. La idea de una mesa forestal o de otro mecanismo de consulta debería asociar la demanda de investigación con la que se realice y no, como en la actualidad, que son los investigadores los que deciden el uso del recurso presupuestal.
Finalmente, se promoverá enérgicamente la asociatividad de los pequeños y medianos productores de madera en plantaciones, así como de núcleos de desarrollo industrial o centros de transformación (clústeres) en zonas estratégicas aptas para la producción forestal, donde el Estado a nivel multisectorial y multinivel provea los servicios y bienes públicos (agua, luz, carreteras, etc.). Este conjunto de medidas inéditas debería resultar en incremento del interés de agricultores, comuneros, inversionistas y empresarios de una industria basada en esas plantaciones.

\section{Disponer de una industria forestal eficiente y próspera}

¿Qué hacer para cambiar la realidad de la industria forestal nacional? La primera respuesta es, obviamente, producir más materia prima, más diversificada, en forma regular, con homogeneidad y buena calidad, tanto proveniente de bosques naturales como de plantaciones forestales. Es evidente que falta coordinación entre las empresas que extraen o producen madera hasta el nivel de aserrío y empresarios los dedicados a su procesamiento. El desabastecimiento de madera adecuada es una de las principales causas de la situación de la industria del sector. Pero, no es la única. La industria de primera transformación de la madera debe ser modernizada, apuntando al cambio del formato de sus productos, ajustándolos a los estándares internacionales y ofreciendo al mercado productos dimensionados y secos que puedan competir con los importados. De esa forma mejorará sus niveles de competitividad en el mercado. Asimismo, es vital impulsar nuevas industrias, en especial para sustituir las importaciones.

El tema de la industria forestal ha sido ampliamente abordado (Barrantes y Trivelli 1996) y recientemente, en el documento borrador del Plan Nacional Forestal y de Fauna Silvestre (SERFOR 2019) que plantea como objetivo estratégico un desarrollo industrial sostenible, con productos de mayor valor agregado, y su fomento con enfoque inclusivo, en busca la generación de una economía forestal competi- 
tiva que fortalezca los emprendimientos existentes e incentive nuevos negocios en el sector que servirían para dinamizar el empleo local. Para lograrlo propone dos grupos de acciones: (i) cadenas de valor forestal y de fauna silvestre fortalecidas con enfoque de mercado, para beneficio de los actores concernidos y; (ii) una serie de instrumentos y mecanismos que contribuyen a demostrar el origen legal de los productos forestales y de fauna silvestre nacionales implementados, en beneficio de la población. Las acciones referidas a las cadenas de valor incluyen: fomento a la asociatividad de productores forestales con énfasis en la generación de una oferta estable, generación de servicios a la producción (secado, preservación, conexión con mercados, definición de productos forestales y de fauna silvestre prioritarios por región, promoción de la gestión de residuos del aprovechamiento y transformación de la madera, promoción del uso y propiedades de plantas medicinales en las páginas web de las entidades del Estado correspondientes y promoción de prácticas ambientalmente amigables a lo largo de todas las cadenas productivas.

Entre los instrumentos previstos se mencionan: promoción de la producción de madera orientada a las compras públicas, desarrollo de herramientas de promoción comercial y participación en ferias para la articulación de productores forestales a los mercados nacionales e internacionales, identificación de áreas prioritarias y generación de parques industriales forestales pilotos, mejora vial en locales con parques industriales, desarrollo de modelos empresariales considerando los requerimientos del mercado nacional e internacional para productos priorizados, apoyo a productores que incursionan en el desarrollo de nuevos procesos y productos, identificación y promoción de productos forestales y de fauna silvestre para nichos de mercado, etc.

A lo anterior, cuya necesidad es obvia, se añade que es crítico actuar más concertadamente (SERFOR, gremios productivos y empresas) para mejorar la integración del sector forestal a otros sectores de la economía en el contexto de la regionalización. Esta acción es- tratégica debería partir del SINAFOR (Sistema Nacional de Gestión Forestal y de Fauna Silvestre) y requiere buscar y mostrar evidencias de la contribución de los bosques y el sector como tal hacia estos sectores. También se debe ampliar la demanda interna por madera y la mejor estrategia es promover el uso de la madera en construcción (viviendas, escuelas, postas, etc.) y el consumo de productos de valor nutricional, medicinal, cosmético, artesanal y para procesos industriales, derivados de productos forestales no maderables. Es necesario elaborar planes estratégicos de desarrollo forestal integrado a nivel macrorregional considerando cuencas de abastecimiento de madera, las fuentes de suministro del bosque natural productor y de plantaciones existentes y por desarrollar; y los mercados regionales, nacional y de exportación. A través de esta planificación se buscará ubicar clústeres forestales que optimicen todos los eslabones de la cadena productiva. Como para otros aspectos de la gestión del bosque, la industria se beneficiaría mucho de una simplificación de los procedimientos para establecer y operar empresas forestales de transformación (MIPYMES) y apoyarlas por al menos tres años (formalización, organización, planes de negocio, capacitación, acceso a financiamiento "blando", búsqueda de mercados, asistencia técnica). Finalmente, es indispensable fortalecer la capacidad institucional técnica y operativa para la investigación, la innovación tecnológica y el desarrollo de capacidades para el desarrollo y consolidación de una industria forestal competitiva.

Pero, al final, en el tema industrial como en otros del sector forestal, lograr lo que se propone dependerá de la adopción, realmente nacional, integral e intersectorial, del propósito de aprovechar bien el patrimonio forestal nacional. Sin esa decisión política el resultado será lento y muy imperfecto.

\section{Brindar oportunidades a indígenas y cam- pesinos}

Gran parte del mundo natural o seminatural del Perú pertenece a comunidades campesinas y nativas. El IBC (2016) registró que en 2016 existían 6120 comunidades campesinas 
que ocupaban 23,8 millones de hectáreas y 2 009 comunidades nativas que abarcaban 12,2 millones de hectáreas. Estas últimas ubicadas en la Selva, están en gran parte cubiertas de bosques naturales. Pero eso es apenas parte de la realidad pues existen asimismo reclamos de reconocimiento y titulación de comunidades campesinas y nativas sobre 4,8 y 5,7 millones de hectáreas, respectivamente. Como antes señalado, el IBC (2016) también anota que en la Amazonia existen unas 2400 comunidades de ribereños que podrían reclamar unos 16,3 millones de hectáreas, siendo que apenas se les ha reconocido unas 305000 ha. La relevancia para el sector forestal de este universo de habitantes, de tierras muchas de ellas de aptitud forestal y de bosques y otros ecosistemas naturales es enorme. Pese a ello, es muy escasa la atención que las políticas forestales del pasado dieron a este asunto y, especialmente, a la oportunidad que representa.

En efecto, de acuerdo con el IV Censo Agropecuario de 2012 (INEI 2012), la superficie agropecuaria (la suma de la superficie agrícola y la no agrícola) es de 38,7 millones de hectáreas. De estas, solo el 18\% (7,1 millones de hectáreas) es tierra apta para cultivos y el $82 \%$ es superficie no agrícola. Las comunidades campesinas controlarían el $42,2 \%$ de la superficie agrícola mientras que las comunidades nativas tendrían otro $18,3 \%$. Sumadas las tierras comunales representarían el 60.6\% de la superficie agropecuaria (del Castillo 2014). Es decir que la mayor parte de las tierras de propiedad comunal, que representaban el 27,3\% del territorio nacional, es tierra no apta para agricultura pero que desempeña o puede desempeñar diversos roles forestales, tanto en cuanto a servicios ambientales como para la producción de madera y otros productos.

Ya se mencionó, especialmente en el caso de las comunidades campesinas andinas, el potencial que ofrecen para la reforestación con fines industriales. Pero también es en ellas que debe realizarse el mayor esfuerzo de restauración de tierras degradadas. Asimismo, ofrecen una oportunidad especial para el manejo de la fauna silvestre, siendo la vicuña la opción más obvia, la más estudiada y la de mayor valor (Hofmann et al. 1983) pero, obviamente, dependiendo del lugar existe buenas posibilidades para muchas otras especies, como guanaco, suri, venado, etc., sin mencionar las posibilidades turísticas de muchos lugares de las comunidades en las que, además de la naturaleza, se conjugan aspectos culturales y arqueológicos considerables, posibilitando promover el turismo vivencial, como ya existe incipientemente en algunas regiones.

En el caso de las comunidades nativas el primer y más lógico uso de la parte de sus espacios boscosos es dedicarlos al manejo forestal para producir, de manera sostenible, madera certificada preciosa, de alto valor (Cossío et al. 2014) Nadie mejor que los indígenas para aprovechar cuidadosamente el bosque que siempre han conocido. Eso combina bien con su mentalidad, habilidad y costumbres ancestrales. Muchas comunidades han sido engañadas para usar sus bosques, dejándolas en situación delicada (Sierra 2018). Pero no tiene que seguir siendo así. Por supuesto, se debe comenzar en pequeño, con un gran apoyo técnico y financiero y/o con la ayuda de madereros honestos, que existen, bajo la supervisión de las instituciones públicas. Dos o tres reservas indígenas contiguas pueden asociarse y tener asesoramiento conjunto y compartir equipos y maquinarias. Al principio, requerirán, además de mucha asistencia técnica, apoyo organizativo y contable, pero como se ha demostrado con varias experiencias en el país, pueden funcionar muy bien y ser rentables (Andina 2020a, AgroPerú 2021).

Hay mucho más que los indígenas pueden hacer para mejorar sus economías y, por cierto, para impulsar su propia calidad de vida. Por ejemplo, en las comunidades hay mucha vegetación secundaria o purma, debido a la práctica tradicional de "roza y quema". Esas largas rotaciones permiten producir madera de rápido crecimiento, que es barata pero que tiene cada vez más demanda. Para eso existen técnicas bien conocidas, simples y de bajo costo (Dourojeanni 1987; Smith et al. 1997, 2002, 2005; Sabogal et al. 2002; Ferreira et al. 
2010; AIDER y FAO 2015a). Obviamente, hay posibilidades enormes para cosechar productos forestales secundarios, como jebe y tantas otras, como resinas, aceites, nueces y frutas o de entrar en el tema casi ilimitado de las plantas medicinales, ornamentales u otras para usos especiales (Brack 1999, 2003). Obviamente, la caza y la pesca tienen muchas posibilidades si se practican bajo un manejo estricto (Dourojeanni 2005), como lo hacían antes los mismos nativos. La recolección y cría de insectos o la extracción de venenos de serpientes y arañas, por ejemplo, es una actividad creciente y rentable en varios países amazónicos. Las áreas preservadas en cada reserva o comunidad sirven como refugios y centros de repoblamiento de la fauna silvestre.

No hay ninguna razón por la que los indígenas no puedan hacer agricultura, ganadería, silvicultura o piscicultura. Es evidente que no se considera prudente que en las tierras indígenas se deforeste áreas para grandes especulaciones agropecuarias, sean propias o de terceros. Pero ya existe tierra deforestada en las comunidades $y$, a medida que crecen sus poblaciones, necesitarán más tierra para cultivar, tanto para su propia alimentación como para el comercio. Nuevamente, se trata de escoger los productos tradicionales más rentables. Por ejemplo, los indígenas han domesticado plantas que hoy tienen una gran demanda, como el huasaí y el pijuayo, y docenas más que aún esperan ser más conocidas a nivel mundial (Brack 1999, 2003; Bager 2005). Planes de negocio bien pensados pueden abrir muchas posibilidades para todas estas especies (AIDER y FAO 2015b). La plantación de árboles para madera u otros usos, es otra opción disponible. En este caso mejor con especies nativas más valiosas. Lo mismo es cierto para la piscicultura, especialmente si se hace con especies nativas, en cuerpos de agua naturales y, si se hacen pozas o lagunas artificiales, alimentando los peces con productos locales o sus residuos. De otra parte, tener algunas cabezas de ganado vacuno o porcino, entre otras especies, puede ser beneficioso, contribuyendo a suplir la dieta proteínica. Lo que no es conveniente, obviamente, es deforestar para criar estos animales.
Es evidente que en muchos casos el turismo o el ecoturismo es otra posibilidad que, como el manejo forestal y algunas otras potencialidades, requiere de mucha capacitación, de capitales relativamente importantes y de una relación armoniosa y equitativa entre indígenas e inversionistas (Valcuende et al. 2012, Gaviria y Sabogal 2013). Por eso también se espera que los equipos profesionales que ayuden a los indígenas sean capaces de definir y medir la existencia de oportunidades y de promoverlas si fuera el caso (Eke et al. 2016). Es obvio que cada iniciativa debe comenzar en pequeña escala, hasta que los propios indígenas sientan que pueden dar un paso más, paso a paso. Finalmente, también vale la pena considerar el tema de la minería, si es precedida de estudios de impacto ambiental serios. No es lógico que otros puedan practicarla, legal o ilegalmente, en los límites de las reservas mientras que lo mismo se prohíbe a los indígenas.

La práctica del manejo forestal y de otras actividades económicas antes mencionadas, requiere de una estructura de apoyo que aún no existe y que se propone se establezca progresivamente en las comunidades que las acepten. Podrían tomar la forma de unidades técnicas, instaladas en las aldeas principales y que podría atender a una o más reservas indígenas. En ellas, se instalarían en forma permanente pequeños grupos de profesionales dispuestos y capacitados. Estos equipos deben estar permanentemente in situ, ser versátiles, autónomos y bien presupuestados. Los técnicos, además de ser competentes en su oficio, deben ser capaces de entusiasmar y capacitar a los líderes y especialmente a los jóvenes indígenas, de modo a asegurar que ellos tengan siempre el papel principal. Para llevar adelante un programa como ese necesita recibir prioridad nacional, beneficiarse del concurso de las agencias especializadas de todos los sectores públicos y claro, recibir el financiamiento adecuado. Un programa así debe ser de largo plazo o permanente, pero debe comenzar en una escala discreta que crecerá con el aprendizaje de cada año (Dourojeanni 2008).

Con relación a los comuneros y campesinos en todo el territorio nacional, la política 
propuesta pretende asociarse y armonizar estrechamente con la Estrategia Nacional de Agricultura Familiar (MINAGRI 2015) y, por lo tanto, buscará apoyar a los productores agropecuarios en la gestión de sistemas agroforestales, así como para el uso sostenible de los ecosistemas forestales existentes en sus propiedades. Se reconoce, pues, que la agroforestería es una alternativa para la recuperación de tierras degradadas o deforestadas, teniendo un interés social y de lucha contra la pobreza.

Asimismo, se promoverán paquetes y alternativas financieras y tecnológicas para el desarrollo e implementación de los sistemas agroforestales con asistencia técnica y financiera, con apoyo del Estado. Para ello se establecerá y operará un fondo para pagos por servicios ecosistémicos al que puedan acceder los titulares de predios privados, para financiar un conjunto de opciones y técnicas sostenibles de uso de la tierra que favorezcan la biodiversidad, la conservación de suelos y aguas, la captura de carbono y el enfoque de paisaje, y promueva el uso de especies nativas de manera preferente. Finalmente, se fomentarán las transacciones de intercambio comercial de los bienes y servicios producidos por el manejo y conservación de los bosques y otros ecosistemas de vegetación silvestre que se encuentren en los predios privados titulados.

\section{Las instituciones funcionan y las leyes son obedecidas}

La aplicación de la nueva gestión del bosque que se propone, es decir de la nueva política forestal, requiere, evidentemente, que sea plasmada en textos legales. De una parte, deberá rediseñarse la ley forestal y, por ende, sus reglamentos, los que deberán ser más simples, permitiendo su adaptación a la realidad regional, para incluir las muchas propuestas hechas, tanto las que difieren de lo que la ley dispone actualmente o las que no existen en esta. De otra parte, es recomendable que la próxima legislación forestal sea ordenada en cinco o más nuevos textos legales: (i) una ley para los bosques y ecosistemas naturales; (ii) una ley para las plantaciones forestales; (iii) una ley para la fauna silvestre, (iv) una ley de Áreas Naturales Protegidas, que ya existe, pero que requiere mejoras y; (v) una ley específica para la titulación de tierras en áreas deforestadas. Es posible que se requiera de un sexto texto legal específicamente para los asuntos relativos a restauración de tierras y ecosistemas degradados, incluyendo asimismo lo que trata de normas de protección de bosques y vegetación natural con función protectora. Las nuevas leyes deben ser simples, breves y concretas, dejando lugar para adaptaciones reglamentarias a la realidad regional. Pero, evidentemente, no todo lo que la política propone se resolverá con cambios legales. Mucho deberá ser abordado con planes, programas y proyectos que canalicen inversiones a la solución de problemas concretos.

Deberá resolverse el problema de la institucionalidad para tratar del patrimonio forestal nacional, la cual está fracturada, es extremadamente ineficiente y está afectada por prácticas corruptas. Aparte de depender de tres ministerios y de otras tantas agencias además de las autoridades regionales, en las que el fraccionamiento se repite, la mayor competencia profesional se encuentra concentrada en las capitales, lejos de los bosques que deben ser manejados. De otra parte, el problema más importante de la política forestal, es decir la deforestación, no es responsabilidad de los tres sectores que se ocupan del tema forestal, ni en lo que se refiere a causas ni tampoco a los posibles remedios. Por eso, la nueva legislación, como la política que va a aplicar, se caracterizará por ser nacional, integral y transectorial y deberá ser obedecida por todos los poderes del Estado, niveles, sectores e instancias de gobierno. Estará integrada en el Plan Nacional Estratégico de Desarrollo y en otros instrumentos de política y a los acuerdos globales vinculantes.

Las instituciones que se ocuparán de aplicar la nueva política y sus leyes deberán reordenarse. La mejor opción es, sin duda, la creación de un Ministerio de los Recursos Naturales Renovables que reúna, en servicios especializados, la gestión de los bosques y de otros ecosistemas naturales, de la pesca, la fauna silvestre 
y, probablemente, del agua. El SERFOR continuaría siendo la institución técnico-normativa rectora para los bosques y otros ecosistemas naturales y debe ser incorporada al nuevo ministerio, pero la reforestación debería quedarse en el Ministerio de Agricultura (MINAGRI). La fauna silvestre debería pasar a depender de un servicio nacional de la fauna en paralelo con el servicio nacional de la pesca. La figura de los servicios, como autarquías gobernadas con cierta independencia y en base a consejos administrativos representativos, con voz y voto, sería más adecuada.

El Ministerio del Ambiente (MINAM) no sería alterado, excepto que dejaría de administrar su programa de bosques que pasaría al SERFOR. El SERNANP continuaría dependiendo del MINAM. Pero el amplio tema de la restauración de ecosistemas degradados debería convertirse en una nueva tarea de este ministerio o del que se establezca para cuidar de todos los recursos naturales renovables, posiblemente también bajo la forma de un servicio especializado. Obviamente el OSINFOR desaparecería, ya que sus funciones nunca debieron dejar de ser las propias y típicas del SERFOR.

El MINAGRI deberá asumir la responsabilidad principal en la tarea de evitar la deforestación usando proactivamente los medios que dispone, en especial el planeamiento del desarrollo agropecuario con respeto a la intangibilidad de los bosques naturales, su capacidad de brindar asistencia técnica así como incentivos económicos y fiscales que las leyes vigentes brindan a la agricultura, de modo a promover un uso más intensivo de la tierra deforestada y a aumentar la productividad y producción sin deforestar. El Ministerio de Transportes y Comunicaciones deberá evitar planear y construir carreteras que atraviesan ecosistemas naturales y controlar eficientemente la proliferación de vías ilegales. En cambio, deberá mejorar la calidad de la vialidad en las áreas ya deforestadas en las que el Ministerio de Agricultura actúa.

El nuevo Ministerio de los Recursos Naturales Renovables que aquí se propone, se con- stituirá como el ente rector y normativo de la nueva política nacional forestal y de las políticas conexas, así como del ordenamiento jurídico único y articulado para la conservación de los bosques y otros ecosistemas naturales en el Perú. Se propone mantener y mejorar el Sistema Nacional de Gestión Forestal y de Fauna Silvestre (SINAFOR), presidido por el ministro de Recursos Naturales Renovables como sistema funcional de articulación y coordinación multisectorial e intergubernamental. Asimismo, instalar el Consejo Forestal Nacional, como ente deliberativo para la gestión del patrimonio forestal nacional, integrado por representantes de los sectores públicos, empresas privadas madereras, empresas de reforestación, comunidades indígenas y campesinas, academia, extractores forestales y sociedad civil.

Lo crucial en la gestión forestal es el manejo del bosque y este, como debería ser obvio, se realiza en el propio bosque. Por tanto, esa labor corresponde a los gobiernos regionales (GORE's) ya que los servicios nacionales si bien son entes rectores, en la práctica son solo técnico-normativos. En efecto, la acción se da en las regiones que actualmente cuentan con administraciones forestales regionales. Lo que se propone, además de fortalecer la actualmente tan limitada capacidad de gestión regional, es aplicar, en cada región, una subdivisión del espacio forestal con unidades administrativas mucho más locales, es decir más cerca al bosque que en la actualidad y con enfoque de cuencas o, en la Selva Baja, con sedes estratégicamente ubicadas en las desembocaduras o bocas de las cuencas, en las que confluyan las autoridades para la gestión del Patrimonio Forestal Nacional incluido en sus límites. Durante las décadas de 1960, 1970 y parte de 1980 el bosque fue dividido en varias decenas de distritos forestales que, en los años 1970, fueron asociados a los distritos de agua y a los límites de las cuencas hidrográficas, donde eso era posible. Este esquema funcionó bien, permitiendo una gestión local ajustada del recurso. Por eso se plantea que los distritos forestales vuelvan a ser creados, con los límites que hoy resulten más adecuados, como base para la gestión y el manejo de los 
bosques por el propio Estado que esta política plantea. En efecto, el área de bosques, tanto los de producción como los de protección, puede ser estratégicamente dividida en unidades de manejo, distritos o cantones forestales, incluyendo las concesiones forestales y los bosques contenidos en comunidades nativas o campesinas. Cada distrito dispondría de un equipo de profesionales (forestal-jefe, personal profesional y técnico, guardabosques o custodios forestales) que serían responsables de hacer y aplicar el plan de manejo de los bosques públicos del distrito y de supervisar el manejo en concesiones y comunidades, de acuerdo con la legislación. El jefe del distrito y sus funcionarios estarían estrechamente supervisados y fiscalizados por el consejo de gestión forestal del distrito, en el que estarían representadas con voz y voto todas las partes interesadas en el ámbito del distrito.

Lo anterior presupone que se complete el proceso de transferencia de competencias y funciones a los GORE's y que se brinde apoyo científico y técnico, además de entrenamiento y supervisión, así como asesoría jurídica para la implementación de las competencias y funciones transferidas.

Especial atención debe ser dada al tema de la cooperación técnica y financiera internacional. Lo cual implica disponer de una política clara con estrategias definidas que identifiquen las necesidades y prioridades y, especialmente, los nichos en los que determinadas fuentes de cooperación pueden ser particularmente útiles. La preparación de los proyectos debe ser cuidadosa, con metas y procedimientos de monitoreo y evaluación muy bien definidos. Además, debe estar atada a ejercicios de planeamiento ampliamente coordinados entre el nivel nacional y el regional y entre las agencias que deben participar. Pero es importante limitar el oportunismo. Los proyectos de cooperación, especialmente financieros, deben responder a los intereses nacionales y no, como suele ocurrir, a los criterios de los aportantes o donantes que, aunque con buena intención, pueden no responder a la realidad. De otra parte, es mejor diseñar proyectos de largo plazo, con aportes anuales menores los que, en general, tienen más éxito que los que aportan muchos recursos en poco tiempo, dadas las limitaciones habituales de gestión administrativa (Dourojeanni 2008). La organización de los donantes y aportantes en la llamada mesa de bosques o mesa verde debe ser vista como una oportunidad para evitar duplicaciones y mal entendidos, pero, a la vez, puede limitar el acceso a algunas fuentes.

Finalmente, deberá hacerse un gran esfuerzo para devolver la dignidad y la motivación a la función pública, tan venida a menos. Ser funcionario público es una gran honra. Es una oportunidad especial de servir a toda la sociedad. Pero uno de los grandes problemas de la gestión pública peruana actual es la falta de motivación de sus funcionarios (Dourojeanni 2019c). La mayoría de los que actúan en el servicio público piensan mucho más en sus derechos que en sus deberes o en sus propias responsabilidades para mejorar el devenir de la sociedad a la que pertenecen. Pocos están interesados en "hacer", pues eso implica un gran esfuerzo, y lo que es peor, constituye un riesgo. Y claro, la gestión pública se paraliza. Los problemas no se resuelven, apenas se transfieren, acumulan y agravan. En parte, eso se debe a la falta de líderes. Las reparticiones públicas tienen jefes, pero no tienen líderes respetados y escuchados que principalmente no consiguen que sus funcionarios se sientan parte de una causa que vale la pena. Como bien lo recuerda Naim (1994) ellos son la pieza fundamental de las instituciones, pero necesitan motivación y esta no sólo depende de sus salarios sino especialmente del ejemplo y del respaldo de sus líderes.

Lamentablemente, el sector forestal además de estar dominado por la informalidad se encuentra muy afectado por la corrupción (MINAGRI 2010b). La corrupción administrativa, la cual es una forma de corrupción especialmente difícil de combatir debido a su carácter sistémico y generalizado (MINAGRI 2010b). Se trata, en general, de acciones de pequeña cuantía, pero muy numerosas y completamente incrustadas en el quehacer diario de los funcionarios de todo nivel. Asimismo, se producen muchos 
casos graves, en que parte de la administración es capturada por intereses privados, lo que es más notorio en aquellas donde el negocio forestal es usado por el narcotráfico para lavar activos mal habidos (Pautrat et al. 2010, Proética 2019, Sierra 2020). La corrupción no solamente se refiere a la extracción ilegal y al tráfico de madera o a evadir los pagos debidos al Estado, sino que es especialmente impactante en la aceleración de la deforestación mediante permisos o justificaciones impropias de cambio uso de la tierra. En realidad, la corrupción ha sido uno de los grandes factores determinantes de la ineficacia de la legislación forestal pasada $\mathrm{y}$ vigente.

Por eso es prioritario lograr que en el nuevo sector forestal se exhiban altos estándares de excelencia e integridad, reduciendo drásticamente la corrupción institucional, corporativa y gubernamental a través de intensos procesos educativos y formativos, así como de mejoras significativas en los sistemas de cumplimiento de la ley, simplificando los sistemas administrativos y aplicando nuevas tecnologías que reducen los márgenes de discrecionalidad y en las oportunidades para la corrupción administrativa (Ramos y Peters 2021). La denominada trazabilidad de la madera es, entre otras, una oportunidad disponible desde octubre de 2019 (norma RDE N²30-2019-MINAGRI-OSINFOR-DE), que contiene los mecanismos de seguimiento de la madera desde su extracción en el bosque hasta su comercialización. Otra opción, también en uso, es la contratación de certificaciones forestales de prestigio, pero que resulta costosa y no es siempre eficaz (van der Ven y Cashore 2018).

La expansión drástica del cultivo de coca ilegal en el Perú es un tema muy asociado al de la corrupción en el sector forestal. En 2019 los cultivos de coca en el Perú se habían incrementado a aproximadamente 75000 ha gracias a la introducción de la variedad colombiana que crece bien en tierras bajas, ocupando áreas extensas de Loreto y Ucayali e invadiendo Áreas Naturales Protegidas y tierras indígenas. Por eso, tanto el narcotráfico como la minería aluvial ilegal, deben ser enérgicamente reprimi- dos, mediante la intervención eficaz de todos los órganos competentes y no solamente de la fuerza pública.

Pero en el nuevo sector forestal se considera que la mejor opción de frenar la corrupción serán la transparencia y la democracia que brindarán la participación con poder decisorio de todos los actores de la temática forestal, en todos los niveles de la gestión. Comenzando a nivel nacional con el Consejo Forestal Nacional, con los consejos forestales regionales y, especialmente, en cada distrito forestal que es donde se dan los mayores riesgos de corrupción. Cada parte, madereros, industriales, campesinos, indígenas, otros sectores públicos, academia u organizaciones no gubernamentales, tiene intereses propios y divergentes, permitiendo que, si la información es abierta como debe ser, se puedan controlar los unos a los otros y, en especial, supervisar las acciones, presupuesto y gastos en que incurre la administración del distrito forestal. Aunque las normas de la gestión y los principios del manejo forestal no deben ser avasallados, dentro de sus límites y alternativas, las decisiones serán del conjunto, por mayoría.

\section{Fortalecer y mejorar la investigación y la ed- ucación}

A partir de la realidad (Malleux 2013, OSINFOR 2017) se propone una reforma de la educación forestal en sus niveles operario, técnico, ingeniero y posgrado, procurando personal calificado, innovador y competente para actuar especialmente en el campo y en la gestión pública, con ética y compromiso en los distintos campos que demanda el sector forestal. En el pasado, con asistencia técnica internacional, fueron creadas escuelas o centros de capacitación permanente de operarios y de técnicos forestales todas las que, pese a su indudable éxito en formar personal altamente calificado, fueron todas abandonadas (Shirley 1968; Dourojeanni 1986a, 2009b). Las causas principales fueron, de una parte, su desconexión con la industria forestal que no participó en su diseño ni en sus costos y que no compensó justamente el servicio que ese personal ofrecía. Es por ello 
que parte de los técnicos prefirió buscar títulos universitarios. Por eso algunas de esas iniciativas dieron lugar a facultades forestales. De otra parte, se debe al desinterés de los sucesivos gobiernos que nunca integraron esas operaciones a sus obligaciones normales y que tampoco les dedicaron presupuesto regular, a pesar de ser relativamente bajos.

Actualmente existe proporcionalmente una sobreproducción de ingenieros, en gran parte no formados para la realidad que les toca enfrentar, mientras que se mantiene un enorme déficit de profesionales de mando medio y de operarios calificados en temas como afilado, inventarios, censos, etc. Es frecuente que la forestería sea encargada a profesionales como los ingenieros ambientales, sin mencionar biólogos, que apenas tienen una vaga noción del tema. Por eso es esencial la valorización de la profesión de ingeniero forestal y posiblemente, establecer estándares especiales para los que manejen el bosque. Un estudio relativamente reciente sobre la problemática de la formación en el sector forestal (SERFOR/GIZ 2016) recomienda especialmente reforzar la relación entre las empresas demandantes del servicio y las instituciones, así como hacer un mejor seguimiento sobre los egresados.

Por las razones expuestas esta nueva política pretende: (i) establecer por efecto de la ley una o más escuelas o centros de formación de mandos medios forestales (peritos o técnicos y operarios especializados); (ii) reconocer la profesión de guardabosque, incluyendo el establecimiento de un centro de formación para ellos y; (iii) reformar progresivamente la enseñanza a nivel universitario de las ciencias forestales y ciencias de la conservación, orientadas a los cambios y retos globales actuales. La reforma de la enseñanza a nivel profesional, además de abordar los problemas antes señalados, deberá enfatizar en las relaciones de la forestería con otras disciplinas, en especial con su responsabilidad social. Habida cuenta del hecho que la población peruana tiene poco conocimiento sobre el patrimonio forestal nacional y sobre la naturaleza en general, se prevé que el Ministerio de Educación en conjunto con el propuesto nuevo Ministerio de Recursos Naturales Renovables y el Ministerio del Ambiente lancen una campaña de largo plazo para reformar gradualmente los programas de educación primaria y secundaria, de modo a incorporar elementos de juicio para que la población nacional comprenda mejor su relación con los bosques y los demás ecosistemas naturales, con lo cual pasaría a comportarse mejor, con mayor responsabilidad, otorgándole un soporte político a través de la opinión pública.

La investigación forestal se realiza tanto en las universidades como en el sector gubernamental, evidentemente, nuestro país se beneficia de los trabajos y estudios que se realizan en los centros internacionales de investigación, así como de los que algunas organizaciones no gubernamentales desarrollan (INIA 2018). En el caso de las universidades es bastante desordenada, respondiendo al interés de cada profesor, de los estudiantes o, simplemente, depende de las oportunidades. Además, en el caso de las tesis de grado, estas suelen ser intrascendentes. En el Estado la investigación es un poco más organizada, pero es muy escasa y continúa enfrentando graves problemas. El SERFOR acaba de concluir un ejercicio de planeamiento (SERFOR 2020) que confirma la situación precaria de la investigación forestal por diversos motivos entre los que destacan, ahora como antes, el reducido presupuesto que se le dedica, el limitado número y baja capacitación de los investigadores, la desconexión entre los actores, la falta de vinculación de la investigación con la demanda por parte del sector privado y el poco aprovechamiento de los resultados por falta de mecanismos de extensión. El plan de gestión propuesto por el SERFOR procura, obviamente, subsanar estos problemas, pero se queda corto con sus propuestas muy encasilladas en la burocracia dominante, siendo poco probable que haga una diferencia significativa.

Siendo el financiamiento el problema principal, la nueva política propondrá un impuesto o un auto gravamen a ser aplicado a las utilidades de los negocios basados en productos forestales o en el uso consuntivo o no del patrimonio forestal nacional. Este recurso se destinará a las 
instituciones del Estado que se incluyan en el plan de investigación. Además, la investigación forestal y de fauna silvestre deberá pasar a depender del nuevo ministerio y salir del Instituto de Investigación Nacional de Innovación Agraria (INIA), excepto en lo referente a la investigación en plantaciones forestales. Se creará un consejo nacional de investigación forestal donde estarán especialmente representados los aportantes de fondos a través del impuesto creado, además de todos los actores del sector. Este consejo determinará las prioridades de investigación para cada periodo fiscal en el mediano y largo plazo.

\section{Conclusión}

Lo presentado es apenas el esbozo de los fundamentos y, en especial, de la racionalidad que sustenta los cambios que proponen e idearon los autores y todos los que contribuyeron a esta propuesta de nueva relación entre los peruanos con su patrimonio forestal. No es un producto completo ni explica todo. Pero es más que suficiente para justificar la necesidad de hacer algo diferente a lo que con tan ciega insistencia se viene repitiendo por décadas, a pesar de las evidencias de su fracaso.

Los autores consideran que esta propuesta es una invitación a pensar y discutir el tema y, ojalá, a producir el cambio necesario. Algunas partes de la propuesta pueden ser aplicadas en forma relativamente aislada, pero la mayor parte, cuyo tema más importante es el control de la deforestación, sólo tendrá éxito si se aplica como paquete completo. Esta reforma, no tendrá ninguna posibilidad de éxito si no es adoptada como una política nacional en la que más que el sector forestal, la responsabilidad recae en el sector agrario y en todo el gobierno.

Es evidente que aplicar esta propuesta tendrá un costo elevado. Los autores están convencidos de que se puede demostrar que el valor acumulado de sus beneficios directos (aumento de la producción forestal y agropecuaria, generación de empleo, estabilidad social rural) e indirectos (a través de los servicios ecosistémicos, turismo), superará largamente sus costos. Hacer ese cálculo debería ser una próxima etapa en la gesta por lograr que sea adoptada.

Políticamente, lo más difícil será: (i) tomar decisión de prohibir el cambio de uso de los bosques y ecosistemas naturales, es decir, prohibir la deforestación y, después hacerla cumplir $y$; (ii) conseguir detener o restringir significativamente la construcción de carreteras nuevas en la Selva. En ambos casos es evidente que existirá a nivel regional una fuerte oposición a esas medidas que, si no van acompañadas de las ideas detalladas en esta propuesta, no podrán ser realizadas. Importantísimo es la consolidación de la propiedad en todas sus modalidades (estatal, comunal y privada) pues se convierte de facto en freno a la deforestación. De otra parte, la aplicación de esta propuesta necesitará una estrategia de gradualidad en el espacio y en el tiempo.

Hay que insistir en la extrema urgencia de abordar el problema que enfrentan los bosques y otros ecosistemas naturales. El Perú está, más que otros países, gravemente amenazado por las consecuencias del cambio climático. Si el gobierno persiste en no hacer nada y si la sociedad continúa indiferente, el futuro de la Nación será mucho más difícil.

Los problemas expuestos son reales y sus soluciones son tangibles. La necesidad de enfrentarlos es indiscutible y, nada de lo propuesto, aunque pueda parecer difícil, es imposible.

\section{Agradecimientos}

Como explicado, las ideas resumidas por los autores fueron construidas a lo largo de más de dos años de aportes y discusiones en las que intervinieron centenares de personas que representaron a gran parte de los actores del sector forestal peruano. Por eso, los autores expresan su reconocimiento a todos aquellos y aquellas que, estando de acuerdo o no con todas o con parte de las opiniones vertidas en este artículo, dedicaron generosamente tiempo y esfuerzo para revisar las versiones previas, comentarlas, discutirlas y hacer sugerencias que, sin duda, mejoraron la propuesta. Entre muchas otras personas destacaron: Manuel Pulgar Vidal, 
Dennis del Castillo Torres, Josefina Takahashi Sato, José Dance Caballero, Enrique Toledo, Francisco Sernaque, Antolín Huáscar Flores, Lizardo Cauper, Lucila Pautrat, Líder López, Luis Campos Baca, Patricia Iturregui Byrne, Fabiola Muñoz Dodero, Gustavo Suarez de Freitas, Rómulo Coronado Calderón, Carlos Espino Díaz, Víctor Quiroz, Gary Céspedes Martínez, Mauro Rodríguez Cerrón, Teddy Pacheco Gómez, Jorge Chávez, Enrique Gonzales Mora, Elena Li Pereyra, Luis Espinel, Manuel Guariguata, Octavio Carrasquilla, Roberto Kometter, Francisco Medina Castro, Juan Pablo Silva, Alonso Córdova, María Pía Díaz, Claudia Zúñiga, Guillermo van Immerzeel, José Capella, Yolanda Ramírez, Walter Huamaní, Rodrigo Arce, Paola Alfaro Mori, Carlos Alberto Andaluz Westreicher, Luisa Álvarez Benaute, Silvana Baldovino Beas, Antonio Tovar Narváez, Juan Carlos Ocaña, Julio Víctor Ocaña Vidal, Nelson Kroll, Wilfredo Ojeda, Walter Nalvarte, Marco Romero Pastor, Amarilda Luque, Tedi Pacheco, Claudia Zúñiga, Yolanda Ramírez, Raúl de los Ríos, Carlos Cabrejos, Carlos Espino, Ronald Rojas, Carlos Espino, Francisco Medina, Héctor Cisneros, Alonso Fernández y Patricia Hurtado.

\section{Referencias}

ADEX (Asociación de Exportadores, Perú). 2019. Servicios e industrias: boletín informativo (en línea). Lima, Perú. Consultado 18 ago. 2021.Disponible en https://peruforestal.org/ web/pdfs/2019 1.pdf.

Agroperú. 2021. Experiencias exitosas en gestión de bosques con las comunidades nativas, sociedad civil y Estado (en línea). AgroPerú, Lima, Perú; 26 feb. Consultado 13 jul. 2021. Disponible en https://www.agroperu. pe/noticias/experiencias-exitosas-en-gestion-de-bosques-con-las-comunidades-nativas-sociedad-civil-y-estado/.

AIDER (Asociación para la Investigación y Desarrollo Integral, Perú); FAO (Organización de las Naciones Unidas para la Alimentación y la Agricultura, Italia). 2015a. Prácticas de manejo para el uso múltiple sostenible en bosques co- munitarios de la Amazonía peruana: guía para el facilitador. Lima, Perú. 56 p.

AIDER (Asociación para la Investigación y Desarrollo Integral, Perú); FAO (Organización de las Naciones Unidas para la Alimentación y la Agricultura, Italia). 2015b. Análisis de mercados y desarrollo de empresas forestales para el manejo forestal comunitario en la Amazonía peruana: guía para el facilitador. Lima, Perú. $268 \mathrm{p}$.

AIDESEP (Asociación Interétnica de Desarrollo de la Selva Peruana). 2007. La tala ilegal de caoba (Swietenia macrophylla) en la Amazonía peruana y su comercialización al mercado exterior. Lima, Perú. 53 p.

Alegre, JC; La Torre, B. 2012. Sistemas agroforestales en la Amazonia peruana para mitigar efectos de cambio climático (en línea). In Congreso Latinoamericano de la Ciencia del Suelo (19, Mar del Plata, Argentina). Lima, Perú, UNALM. Consultado 20 set. 2021. Disponible en https://www.researchgate.net/ publication/270278206 sistemas agroforestales en la amazonia peruana para mitigar efectos de cambio climatico.

Alianza Periodística. 2021. Perú: más de 600 funcionarios aprobaron documentos fraudulentos que se usaron para el 'lavado' de madera (en línea). Mongabay, s.l.; 28 may. Consultado 20 set. 2021. Disponible en https://es.mongabay.com $/ 2021 / 05 /$ peru-funcionarios-documentos-fraudulentos-lavado-madera/.

Alves, DS. 2001a. An analysis of the geographical patterns of deforestation in the brazilian Amazon during the 1991-1996 period (en línea). In Wood, C; Porro, R (eds.). Patterns and process of land use and forest changes in the Amazon. Gainesville, Estados Unidos de América, University of Florida Press. Consultado 20 set. 2021. Disponible en http://www. dpi.inpe.br/dalves/.

Alves, DS. 2001b. O processo de desflorestamento na Amazônia. (en línea). Parcerias Estratégicas (12):259-275. Consultado 27 jul. 2021. Disponible en http://seer.cgee.org.br/index.php/parcerias estrategicas/article/viewFile/176/170sumarios/padroes2.html. 
Alvim, P. 1972. Desafio agrícola da região amazônica. Ciência e Cultura 24(5):437-443.

ANA (Autoridad Nacional del Agua, Perú). 4 jul. 2020. Perú perdió el 51\% de sus glaciares debido al cambio climático (en línea). Lima, Perú, MINAGRI. Consultado 6 set. 2021. Disponible en https://www.ana.gob.pe/noticia/ peru-perdio-el-51-de-sus-glaciares-debido-al-cambio-climatico.

Andersen, LE; Suxo, A; Verner, D. 2009. Social impacts of climate change in Peru: a district level analysis of the effects of recent and future climate change on human development and inequality (en línea). Washington DC, Estados Unidos de América, World Bank. (Policy Research Working Paper, n. ${ }^{\circ}$ 5091) Consultado 27 ago. 2021. Disponible en https:// openknowledge.worldbank.org/bitstream/ handle/10986/4283/WPS5091.pdf?sequen$\mathrm{ce}=1$ \&isAllowed $=\mathrm{y}$.

Anderson, C; Asner, GP; Llactayo, W; Lambin, E. 2018. Overlapping land allocations reduce deforestation in Peru (en línea). Land Use Policy 79:174-178. Consultado 20 set. 2021. Disponible en https://www.researchgate.net/ publication/329341762 Overlapping land allocations reduce deforestation in Peru.

Andina. 2020a. Amazonas: familias Awajún y Wampis progresan con diversos emprendimientos sostenibles (en línea). Andina, Lima, Perú; 4 jul. Consultado 2 set. 2021. Disponible en https://andina.pe/AGENCIA/noticia-amazonas-familias-awajun-y-wampis-progresan-diversos-emprendimientos-sostenibles-804432.aspx.

Andina. 2020b. Perú contará con cuenta satélite forestal para evidenciar aporte en la economía nacional (en línea). Andina, Lima, Perú; 11 jul. Consultado 20 set. 2021. Disponible en https:// andina.pe/agencia/noticia-peru-contara-cuenta-satelite-forestal-para-evidenciar-aporte-la-economia-nacional-805396.aspx.

Aquino, R; Calle, A. 2003. Evaluación del estado de conservación de los mamíferos de caza: un modelo comparativo en comunidades de la Reserva Nacional Pacaya Samiria (Loreto, Perú) (en línea). Revista Peruana de Biología 10(2):163 - 174. Consultado 4 set. 2021. Disponible en https://es.scribd.com/document/415595430/productividv10n2a07-pdf.

Arce, RS. 2000. La certificación forestal en el Perú (en línea). Bosques Amazónicos (19):3233. Consultado 9 ago. 2021. Disponible en https ://www.academia.edu/33251762/ La certificaci\%C3\%B3n forestal en el Per\%C3\%BA.

Arce, RS. 2018. Alegalidad en el sector forestal, un preocupante tema clave (en línea). Lima, Perú, Servindi. Consultado 6 ago. 2021. Disponible en https://www.servindi.org/actualidad-noticias/05/08/2018/alegalidad-en-el-sectorforestal.

Arce, RS. 2019. ¿De qué desarrollo forestal estamos hablando? (en línea). Lima. Perú, Servindi. Consultado 20 ago. 2021. Disponible en https://www.servindi.org/actualidad-noticias/08/05/2019/de-que-desarrollo-forestal-estamos-hablando.

Arce, RS; Soria, CA. 2019. Nuevas aproximaciones al manejo forestal desde una perspectiva ética humanista (en línea). Paidea XXI 9(1):3752. Consultado 6 ago. 2021. Disponible en http://revistas.urp.edu.pe/index.php/Paideia/ article/view/2262/2289.

Arce, JM; Dourojeanni, M. 1990. Análisis crítico sobre el cumplimiento de la Ley Forestal y de Fauna Silvestre. Revista Forestal del Perú 17(2):3-20.

Arima, E; Walker, R; Perz, S; Caldas, M. 2005. Loggers and forest fragmentation: behavioral models of road building in the Amazon basin. Annals of the Association of American Geographers 95(3):525-541.

Bager, H. 2005. Un inventario de productos forestales no maderables usados por los pobladores en la zona de amortiguamiento de un parque nacional en la Amazonia peruana: una apreciación de la subsistencia y la ecología. Uppsala, Suecia, SLU. 83 p.

Barber, CP; Cochrane, MA; Souza Jr, CM; Laurance, WF. 2014. Roads, deforestation, 
and the mitigating effect of protected areas in the Amazon. Biological Conservation 177:203-209. DOI: https://doi.org/10.1016/j. biocon.2014.07.004.

Barkhordarian, A; Saatchi, SS; Behrangi, A; Loikith, PC; Mechoso, CR. 2019. A recent systematic increase in vapor pressure deficit over tropical South America. Scientific Reports 9(15331):12 p. DOI: https://doi.org/10.1038/ s41598-019-51857-8.

Barrantes, R; Trivelli, C. 1996. Bosques y madera: análisis económico del caso peruano. Lima, Perú, IEP. 121 p.

Barriga, A. 2014. Diagnóstico de la cadena de producción y comercialización de la Caesalpinia spinosa (tara) en el Perú. Lima, Perú, OSINFOR.

Barriga, A. 2020. Sostenibilidad de productos forestales diferentes a la madera. Pucallpa, Perú, Bosques Amazónicos. p. 8-9.

Binkley, CS. 1999. Ecosystem management and plantation forestry: new directions in British Columbia. New Forests (18):75-78. DOI: https://doi.org/10.1023/A:1006506108169.

BM (Banco Mundial, Estados Unidos de América). 2006. Análisis preliminar sobre gobernabilidad y cumplimiento de la legislación del sector forestal en el Perú (en línea). Washington DC, Estados Unidos de América. Consultado 16 set. 2021. Disponible en https://documents1.worldbank.org/curated/ en/965731468099279830/pdf/805050WP0SPANI0Box0379805B00PUBLIC0.pdf.

BM (Banco Mundial, Estados Unidos de América). 2007. Análisis ambiental del Perú: retos para un desarrollo sostenible (en línea). Washington DC, Estados Unidos de América. Consultado 16 set. 2021. Disponible en https:// sinia.minam.gob.pe/documentos/analisis-ambiental-peru-retos-un-desarrollo-sostenible.

Brack, A. 1986. La fauna. In Gran geografía del Perú: naturaleza y hombre. Lima, Perú, Manfer \& Juan Mejía Baca. V. 3.

Brack, A. 1999. Diccionario enciclopédico de plantas útiles del Perú (en línea). Cuzco, Perú,
Centro de Estudios Regionales Andinos Bartolomé de Las Casas. (Serie Ecología y Desarrollo, n. ${ }^{\circ}$ ).

Brack, A. 2003. Perú: diez mil años de domesticación. Lima, Perú, Bruño. 160 p.

Brancalion, PHS; Broadbent, EN; de Miguel, S; Cardil, A; Rosa, MR; Almeida, CT; Almeida, D; Chakravarty, S; Zhou, M; Gamarra, J; Liang, J; Crouzeilles, R; Hérault, B; Aragao, L; Silva, C; Almeyda-Zambrano, A. 2020. Emerging threats linking tropical deforestation and the COVID-19 pandemic. Perspectives in Ecology and Conservation 18(4):243-246. DOI: https:// doi.org/10.1016/j.pecon.2020.09.006.

Brandão, AO; Souza, CM. 2006. Mapping unofficial roads with Landsat images: a

new tool to improve the monitoring of the Brazilian Amazon rainforest. International Journal of Remote Sensing 27(1):177-189. DOI: https://doi.org/10.1080/01431160500353841.

Bravo, F. 5 jun. 2013. ¿Existe una conciencia ambiental en el Perú? (en línea). Punto Edu, Lima, Perú. Consultado 4 set. 2021. Disponible en https://puntoedu.pucp.edu.pe/voces-pucp/ existe-una-conciencia-ambiental-en-el-peru/.

Broadbent, EN; Asner, GP; Keller, M; Knapp, DE; Oliviera, PJC; Silva, JN. 2008. Forest fragmentation and edge effects from deforestation and selective logging in the Brazilian Amazon. Biological Conservation 141(7):17451757. DOI: http://dx.doi.org/10.1016/j.biocon.2008.04.024.

Bruner, AG; Gullison, RE; Rice, RE; da Fonseca, GA. 2001. Effectiveness of parks in protecting tropical biodiversity. Science 291(5501):125128. DOI: https://doi.org/10.1126/science.291.5501.125.

Budowski, G. 1962. La sucesión forestal y su relación con antiguas prácticas agrícolas en el trópico americano. Congreso Internacional de Americanistas (35, 1964, México DF, México). México DF, México. p. 189-196.

Buendía, B. 2014. Analizando la gestión forestal de bosques comunitarios en la Amazonía peruana (en línea). Lima, Perú, ECOREDD. Con- 
sultado 25 jul. 2021. Disponible en http://www. ecoredd.org.pe/wp-content/uploads/2014/09/ Analizando-la-gesti\%C3\%B3n-forestal-de-bosques-comunitarios-en-la-Amazon\%C3\%Ada-PeruanaL.pdf.

Carey, M. 2014. Glaciares, cambio climático y desastres naturales: ciencia y sociedad en el Perú. Lima, Perú, IEP. 343 p.

Carton, C; Chávez, A. 2018. Porcón: medio siglo de forestación en los Andes de Cajamarca - Perú. Lima, Perú, Lluvia. 304 p.

Chávez, G. 1995. El medio ambiente y los recursos naturales en las cuentas nacionales (en línea). Revista de la Facultad de Ciencias Económicas (5):151-164. Consultado 3 ago. 2021. Disponible en https://sisbib.unmsm.edu.pe/ bibvirtualdata/publicaciones/economia/11/ al1.pdf.

Che Piu, H. 2008a. Los nuevos coeficientes de rendimiento para la exportación de la caoba (en línea). Xilema 25(20):64-69. Consultado 7 ago. 2021. Disponible en https://www.academia.edu/15519254/Revista Xilema Vol 20.

Che Piu, H. 2008b. Lucha contra la tala ilegal en el Perú (en línea). Lima, Perú, CES. Consultado 9 ago. 2021. Disponible en https://www.portalces.org/sites/default/files/migrated/docs/1027. pdf.

Che Piu, H. 2018. Legislación forestal peruana ¿Mucha norma jurídica, poca ley y derecho? El dilema del sector forestal peruano (en línea). Consultado 22 abr. 2019. Disponible en http :// dialogosdelareladefa.blogspot.com/2018/04/ legislacion-forestal-peruana-1-che-piu.html

Che Piu, H. 2019. Del SINAFOR sus hijitos: los Sistemas Regionales de Gestión Forestal y de Fauna Silvestre (en línea). Lima, Perú, DAR. Consultado 20 ago. 2021. Disponible en https:// dar.org.pe/archivos/publicacion/diagramacion sinafor.pdf.

Che Piu, H; Galván, O. 2015. La transformación del bosque: titulación de predios y cambio de uso de suelos en la Amazonía peruana (en línea). Lima, Perú, DAR. Consultado 6 ago. 2021. Disponible en https://www.dar.org.pe/archivos/Libro\%20CUS vf.pdf.
Colán, V; Sabogal, C; Snook, L; Boscolo, M; Smith, J; Galván, O. 2006. La extracción maderera en la Amazonía peruana: diagnóstico de prácticas e implicaciones para promover el manejo forestal. Recursos Naturales y Ambiente (49-50):90-99.

Constantino, P; Fortini, L; Sabino, FR; Maia, A; Sales, E; Paulino, A; Sales, L; Maia, J; Pereira, J. 2008. Indigenous collaborative research for wildlife management in Amazonia: the case of the Kaxinawá, Acre, Brazil. Biological Conservation 141(11): 2718-2729. DOI: https://doi. org/10.1016/j.biocon.2008.08.008.

Constitución Política del Perú. Perú. 29 dic. 1993.

Corderi, D; Goy, G. 2017. Análisis del gasto público ambiental en Perú 2008-2013 (en línea). Washington DC, Estados Unidos de América. (Monografía del BID, n. ${ }^{\circ}$ 534). Consultado 4 set. 2021. Disponible en https://publications. iadb.org/publications/spanish/document/ An\%C3\%A1lisis-del-gasto-p\%C3\%Bablico-ambiental-en-Peru-2008-2013.pdf.

Cossío, R; Menton, M; Cronkleton, P; Larson, A. 2014. Manejo forestal comunitario en la Amazonía peruana: una revisión bibliográfica. Bogor, Indonesia, CIFOR. (Documento de trabajo, n. $\left.{ }^{\circ} 140\right)$.

Cubas, C. 2018. Proyectos de cooperación internacional en el sector bosques en el Perú: resumen y análisis (en línea). Lima, Perú, GIZ. Consultado 17 ago. 2021. Disponible en https:// issuu.com/educ007/docs/proyectos de la cooperacion interna.

Da Silva, SS; Fearnside, PM; de Alencastro Graça, PM; Brown, IF; Alencar, A; de Melo, AW. 2018. Dynamics of forest fires in the southwestern Amazon. Forest Ecology and Management 424:312-322.DOI: https://doi.org/10.1016/j. foreco.2018.04.041.

Dammert, JL. 2015. Hacia una ecología política de la palma aceitera en el Perú (en línea). Lima, Perú, Oxfam. Consultado 9 jul. 2021. Disponible en https://peru.oxfam.org/en/node/241. 
Dancé, J. 1980. Tendencias de la deforestación con fines agropecuarios en la selva peruana. Revista Forestal del Perú 10(1-2):177-184.

Dancé, J. 2006. Consultoría de introducción de especies líderes en los mercados de exportación. Lima, Perú, MINCETUR. 104 p. Informe final consolidado. Programa de desarrollo de políticas de comercio exterior 1442/OC-PE.

Defensoría del Pueblo, Perú. 2010. La política forestal y la Amazonía peruana: avances y obstáculos en el camino hacia la sostenibilidad (en línea). Lima, Perú. (Informes Defensoriales, $n$. ${ }^{\circ}$ 151). Consultado 15 abr. 2019. Disponible en https://www.defensoria.gob.pe/wp-content/ uploads/2018/05/informe-151.pdf.

del Castillo, L. 2014. Políticas de tierras vigentes en el Perú (en línea). Lima, Perú, Movimiento Regional por la Tierra. Consultado 2 jul. 2021. Disponible en https://porlatierra.org/docs/ 2056f4ee7112197b36f0e6890ae15619.pdf.

DGFF (Dirección General Forestal y de Fauna Silvestre, Perú). 1974. Plan nacional de desarrollo forestal 1974-1980. Lima, Perú, Ministerio de Agricultura.

DGFF (Dirección General Forestal y de Fauna Silvestre, Perú). 1981. Inventario forestal del bosque seco del Norte: Piura, Tumbes y Lambayeque. Lima, Perú, Ministerio de Agricultura.

DGFF (Dirección General Forestal y de Fauna Silvestre, Perú). 1987. Plan nacional de acción forestal 1988-2000. Lima, Perú, Ministerio de Agricultura.

DGFF (Dirección General Forestal y de Fauna Silvestre, Perú). 1991. Perú forestal en números. Lima, Perú, Ministerio de Agricultura.

Domke, M; Oswalt, SN; Walters, BF; Morin, RS. 2020. Tree planting has the potential to increase carbon sequestration capacity of forests in the United States. PNAS 117(40): 24649-24651. DOI: https://doi.org/10.1073/ pnas.2010840117.

Dourojeanni, MJ. 1972. Impacto de la producción de la fauna silvestre en la economía de la Amazonía peruana (en línea). Revista Forestal del Perú 5(1-2):15-27. Consultado 7 set. 2021. Disponible en https://revistas.lamolina.edu.pe/ index.php/rfp/article/view/1091/0.
Dourojeanni, MJ. 1976. Una nueva estrategia para el desarrollo de la Amazonía peruana (en línea). Revista Forestal del Perú 6(1-2):41-58. Consultado 7 set. 2021. Disponible en https:// revistas.lamolina.edu.pe/index.php/rfp/article/view/1102/0.

Dourojeanni, MJ. 1986a. How good is forestry education today? (en línea). Unasylva 38(4):2231. Consultado 5 set. 2021. Disponible en https://www.fao.org/3/50630E/50630e04.htm.

Dourojeanni, MJ. 1986b. Manejo de la fauna en el Perú. In Gran geografía del Perú: naturaleza y hombre. Lima, Perú, Manfer \& Juan Mejía Baca. V. 5, p. 227-360.

Dourojeanni, MJ. 1987. Aprovechamiento del barbecho forestal en áreas de agricultura migratoria en la Amazonía peruana (en línea). Revista Forestal del Perú 14(2):15-61. Consultado 26 ago. 2021. Disponible en https://www. academia.edu/12950570/Aprovechamiento del barbecho forestal en areas de agricultura migratoria de la Amazonia peruana.

Dourojeanni, MJ. 1990. Amazonía ¿Qué hacer?. Iquitos Perú, CETA. 444 p.

Dourojeanni, MJ. 30 mar. - 20 abr. 2005. Manejo da fauna I-IV (en línea). Río de Janeiro, Brasil, Oeco. Consultado 6 set. 2021. Disponible en https ://www.oeco.org.br/author/marc-dourojeanni/.

Dourojeanni, MJ. 2006. Estudio de caso sobre la carretera Interoceánica en la Amazonía Sur del Perú (en línea). Lima, Perú, BIC. Consultado 19 set. 2021. Disponible en http://siar.minam.gob. pe/puno/sites/default/files/archivos/public/ docs/437.pdf.

Dourojeanni, MJ. 2008. Manejo comunitario de bosques tropicales y cooperación internacional: lecciones no aprendidas (en línea). Bois et Forêts des Tropiques 295(1):48-57. Consultado 30 set. 2021. Disponible en http ://bft.cirad.fr/ cd/BFT 295 47-57.pdf.

Dourojeanni, MJ. 2009a. Agroforestry systems and the environment. ICRAF Amazon Agroforestry 1(2):3-4.

Dourojeanni, MJ. 2009b. Crónica forestal del Perú. Lima, Perú, UNALM. 727 p. 
Dourojeanni, MJ. 2013a. Análisis crítico de la ley forestal peruana (en línea). Boletín Informativo de Derecho, Ambiente y Recursos Naturales 2(4):20-32. Consultado 10 ago. 2021. Disponible en https://www.academia. edu/5669131/Analisis critico de la ley forestal peruana.

Dourojeanni, MJ. 2013b. Loreto sostenible al 2021 (en línea). Lima, Perú, DAR. Consultado 25 set. 2021. Disponible en https://es.scribd. com/document/151905039/Loreto-Sostenible-al-2021-Dourojeanni-Marc.

Dourojeanni, MJ. 12 dic. 2016. Incendios forestales y los bomberos que necesita el Perú (en línea). Lima Perú, SPDA Actualidad Ambiental. Consultado 19 ago. 2021. Disponible en https:// www.actualidadambiental.pe/incendios-forestales-y-los-bomberos-que-necesita-el-peru-escribe-marc-dourojeanni/.

Dourojeanni, MJ. 30 ene. 2017. Bosques nacionales en el Perú: de importantes centros de investigación a zonas deforestadas (en línea). Lima, Perú, SPDA Actualidad Ambiental. Consultado 15 ago. 2021. Disponible en https:// www.actualidadambiental.pe/bosques-nacionales-en-el-peru-de-importantes-centros-de-investigacion-a-zonas-deforestadas/.

Dourojeanni, MJ. 2018. Áreas Naturales Protegidas del Perú: el comienzo (en línea). Lima, Perú, Universidad Nacional de Educación Enrique Guzmán y Valle. Consultado 28 ago. 2021. Disponible en https://www.academia.edu/37923859/\%C3\%81REAS NATURALES PROTEGIDAS DEL PER\%C3\%9a EL COMIENZO.

Dourojeanni, MJ. 2019a. Amazonía peruana ¿Qué futuro? (en línea). Lima, Perú, Grijley. Consultado 28 ago. 2021. Disponible en https ://www.academia.edu/39962447/Amazonia Qu\%C3\%A9 Futuro.

Dourojeanni, MJ. 2019b. Esbozo de una nueva política forestal peruana (en línea). Revista Forestal del Perú 34(1):4-20. Consultado 28 ago. 2021. Disponible en https://revistas.lamolina. edu.pe/index.php/rfp/article/view/1244.

Dourojeanni, MJ. 5 ago. 2019c. ¿Servicio público sin motivación? (en línea). Lima, Perú,
SPDA Actualidad Ambiental. Consultado 25 ago. 2021. Disponible en https ://www.actualidadambiental.pe/opinion-servicio-publico-sin-motivacion-escribe-marc-dourojeannil.

Dourojeanni, MJ. 2020. ¿Es sostenible el aprovechamiento maderero de bosques naturales en el Perú? (en línea). Revista Forestal del Perú 35(2):80-93. Consultado 22 ago. 2021. Disponible en https://revistas.lamolina.edu.pe/ index.php/rfp/article/view/1577.

Dourojeanni, MJ; Barandiarán, A; Dourojeanni, D. 2010. Amazonia peruana en 2021 (en línea). Lima, Perú, Pronaturaleza. Consultado 20 set. 2021. Disponible en https://www.academia. edu/33362223/Amazonia Peruana en 2021 Marc Dourojeanni pdf.

Duffy, KA; Schwalm, CR; Arcus, VL; Koch, GW; Liang, LL; Schipper, L. 2021. How close are we to the temperature tipping point of the terrestrial biosphere?. Science Adavances 7(3):1-8. DOI: https ://doi.org/10.1126/sciadv.aay1052.

Dummett, C; Blundell, A. 2021. Ilicit harvest, complicit goods: the state of illegal deforestation for agriculture (en línea). S.l., Forest Trends. Consultado 3 ago. 2021. Disponible en https://www.forest-trends.org/wp-content/ uploads/2021/05/Illicit-Harvest-Complicit-Goods.pdf.

Eke, J; Gretzinger, S; Camacho, O; Sabogal, C; Arce, R. 2016. Desarrollo forestal empresarial por comunidades: guía práctica para promotores forestales comunitarios en los trópicos americanos. S.l., FAO. 220 p.

El Serafy, S; Lutz, E. 1989. Environmental and resource accounting: an overview. In Ahmad, YJ; El Serafy, S; Lutz, E (eds). Environmental accounting for sustainable development. Washington DC, Estados Unidos de América, BM.

Escobar, H. 2019. Amazon fires clearly linked to deforestation, scientists say. Science 365(6456):853. DOI: https://doi.org/10.1126/ science.365.6456.853.

FAO (Organización de las Naciones Unidas para la Alimentación y la Agricultura, Italia). 2009. The eucalyptus in East Africa: the so- 
cio-economic and environmental issues (en línea). Addis Ababa, Etiopía. Consultado 19 ago. 2021. Disponible en http://www.fao.org/3/ aq401e/aq401e.pdf.

FAO (Organización de las Naciones Unidas para la Alimentación y la Agricultura, Italia). 2010a. ¿Qué es una política forestal nacional? (en línea). Roma, Italia. Consultado 19 abr. 2019. Disponible en http://www.fao.org/3/ i1679s/i1679s03.pdf.

FAO (Organización de las Naciones Unidas para la Alimentación y la Agricultura, Italia). 2010b. Elaboración de una política forestal eficaz (en línea). Roma, Italia. Consultado 20 abr. 2019. Disponible en http://www.fao.org/3/ am007s/am007s00.pdf.

FAO (Organización de las Naciones Unidas para la Alimentación y la Agricultura, Italia). 2015. Agroforestry (en línea). Roma, Italia. Consultado 3 set. 2021. Disponible en http:// www.fao.org/forestry/agroforestry/80338/en/.

FAO (Organización de las Naciones Unidas para la Alimentación y la Agricultura, Italia). 28 mar. 2018. El comercio interno de madera en el Perú, una oportunidad para el aprovechamiento sostenible y legal del bosque (en línea). S.l. Consultado 30 set. 2021. Disponible en http:// www.fao.org/in-action/eu-fao-flegt-programme/news-events/news-eventsnews-archive/es/c/1111643/.

FAO (Organización de las Naciones Unidas para la Alimentación y la Agricultura, Italia). 2021a. ¿Los eucaliptos son ecológicamente nocivos? (en línea). Unasylva 38(152):s.p. Consultado 15 set. 2021. Disponible en http:// www.fao.org/3/r7750s/r7750s03.htm.

FAO (Organización de las Naciones Unidas para la Alimentación y la Agricultura, Italia). 2021b. ¿Qué es una política forestal nacional y por qué debería un país adoptar tal política? (en línea). In Elaboración de una política forestal eficaz: una guía. Roma, Italia. p. 5-17. Consultado 17 ago. 2021. Disponible en http:// www.fao.org/3/i1679s/i1679s03.pdf.

Fearnside, PM. 2008a. Amazon forest maintenance as a source of environmental services.
Anais da Academia Brasileira de Ciências 80(1):101-114. DOI: https://doi.org/10.1590/ S0001-37652008000100006.

Fearnside, PM. 2008b. The roles and movements of actors in the deforestation of brazilian Amazonia. Ecology and Society 13(1):23 p. DOI: http://dx.doi.org/10.5751/ES-02451130123.

Ferreira, M; de Oliveira, LC; Sabogal, C; de Mattos, MM. 2010. Manejo de florestas secundárias: aproveite e maneje bem sua capoeira, ela pode rendir mais benefícios para você, seus filhos e netos. Belém, Brasil, EMBRAPA.

Finer, M; Mamani, N. 2020. Deforestación en la Amazonía 2020 (en línea). Monitoring of the Andean Amazon Project (136). Consultado 16 set. 2021. Disponible en https://maaproject. org/2021/amazon-2020/.

Finer, M; Mamani, N; Garcia, R; Novoa, S. 2018. Hotspots de deforestación en la Amazonía peruana, 2017 (en línea). Monitoring of the Andean Amazon Project (78). Consultado 7 ago. 2021. Disponible en https://maaproject. org/2018/hotspots-peru-2017/.

Finer, M; Snelgrove, C; Novoa, S. 2015. Hotspots de deforestación en la Amazonía peruana, 2012-2014 (en línea). Monitoring of the Andean Amazon Project (25). Consultado 13 ago. 2021. Disponible en https://maaproject. org/2016/hotspots-deforestacion2012-2014/.

Fleck, LC; Vera-Diaz, M; Borasino, E; Glave, M; Hak, J; Josse, C. 2010. Estrategias de conservación a lo largo de la carretera Interoceánica en Madre de Dios, Perú: un análisis económico-espacial (en línea). Lima, Perú, CSF. Consultado 5 set. 2021. Disponible en https://www. conservation-strategy.org/sites/default/files/ field-file/20 IOS 0.pdf.

Flores, H. 2016. ¿Qué pasa con la industria forestal en el Perú? (en línea). América Economía, s.l.; 28 mar. Consultado 4 ago. 2021. Disponible en https://www.americaeconomia. com/negocios-industrias/que-pasa-con-la-industria-forestal-en-el-peru.

Flores, Y. 2012. Crecimiento y productividad de plantaciones forestales (en línea). Lima, Perú, 
INIA. Consultado 5 ago. 2021. Disponible en https://issuu.com/ymber/docs/crecimiento y productvidad de plantaciones foresta/12.

Foley, JA; Asner, GP; Costa, MH; Coe, MT; DeFries, R; Gibbs, HK; Howard, EA; Olson, S; Patz, J; Ramankutty, N; Snyder, P. 2007. Amazonia revealed: forest degradation and loss of ecosystem goods and services in the Amazon Basin. Frontiers in Ecology and the Environment 5(1):3-56. DOI: https://doi.org/10.1890/1 540-9295(2007)5[25:ARFDAL]2.0.CO;2.

Fraser, BJ. 2009. Climate change impacts revealed: disease in Peru (en línea). Scientific American, New York, Estados Unidos de América; 11 may. Consultado 6 ago. 2021. Disponible en https://www.scientificamerican.com/ article/climate-change-disease-peru/.

Fundación Backus. 2015. Ecoparque, generando oportunidades: promoviendo la recuperación del bosque amazónico en Ucayali (en línea). Lima, Perú. Consultado 20 set. 2021. Disponible en https://es.scribd.com/ document/373968504/Ecoparque-Generando-Oportunidades-Backus.

Galarza, E; La Serna, K. 2005. ¿Son sostenibles las concesiones forestales en el Perú? (en línea). Economía y Sociedad (56):34-41. Consultado 29 ago. 2021. Disponible en http://www.cies. org.pe/sites/default/files/files/otros/economiaysociedad/05-galarza.pdf.

García, F. 19 ago. 2020. Perú: tráfico de madera no se detiene con la pandemia (en línea, blog). Lima, Perú, Mongabay LATAM. Consultado 11 ago. 2020. Disponible en https://es.mongabay. com/2020/08/peru-trafico-madera-amazonia-pandemia/? mc cid $=13$ cf68b6e $8 \& m c$ eid=3dfa574eba.

Gauthier, R. 1987. Diagnóstico de los aserraderos de la región Ucayali, provincia de Coronel Portillo. Lima, Perú, Programa de Desarrollo Forestal Perú-Canadá. 143 p.

Gaviria, A; Sabogal, C (eds.). 2013. Sistematización de seis experiencias de manejo forestal comunitario en la Amazonía peruana. Lima, Perú, INF. 90 p.
Giudice, R; Soares-Filho, BS; Merry, F; Rodrigues, HO; Bowman, M. 2012. Timber concessions in Madre de Dios: are they a good deal?. Ecological Economics 77:158-165. DOI: https://doi.org/10.1016/j.ecolecon.2012.02.024.

Global Witness, Reino Unido. 2019. El justiciero forestal: por qué se debe devolver la independencia a OSINFOR y expandir sus poderes (en línea). Londres, Reino Unido. Consultado 20 abr. 2019. Disponible en https://www.globalwitness.org/documents/19591/El justiciero forestal.pdf.

Gómez, A; Gómez, O. 2020. El árbol de la quina (Cinchona spp.) a través de la historia. Pucallpa, Perú, Bosques Amazónicos. p. 10-12.

Guariguata, MR; Arce, J; Ammour, T; Capella, JL. 2017. Las plantaciones forestales en Perú: reflexiones, estatus actual y perspectivas a futuro (en línea). Bogor, Indonesia, CIFOR. (Documento Ocasional, n. ${ }^{\circ}$ 169). Consultado 15 ago. 2021. Disponible en https://www.researchgate. net/publication/317021930 Las Plantaciones Forestales en Peru reflexiones estatus actual y perspectivas a futuro.

Guevara, L; Reyes, P; Bocanegra, L. 1993. Evaluación de residuos de aserrío. Folia Amazónica 5(1-2):191-201.

Herzog, SK; Martínez, R; Jørgensen, PM; Tiessen, $\mathrm{H}$ (eds.). 2011. Climate change and biodiversity in the Tropical Andes (en línea). S.l., SCOPE. Consultado 3 set. 2021. Disponible en https ://museohn.unmsm.edu.pe/docs/pub_ictio/Josse\%202011.pdf.

Hofmann, RK; Ötte, C; Ponce, CF; Ríos, MA. 1983. El manejo de la vicuña silvestre. Eschborn, Alemania, GTZ. T.1-2.

Hopkins, A; Malky, A; Glave, M; Ventocilla, R; Ventocilla, RC; Ventocilla, JC; Arana, A. 2015. Análisis económico y socioambiental de los proyectos de interconexión Pucallpa-Cruzeiro do Sul (en línea). Lima, Perú, CSF. 83 p. Consultado 20 set. 2021. Disponible en http:// conservation-strategy.org/sites/default/files/ field-file/CSF Pucallpa series technical mar2015 web.pdf. 
Huamanchumo, C. 2013. La cadena de valor de maíz en el Perú: diagnóstico del estado actual, tendencias y perspectivas (en línea). Lima, Perú, IICA. 58p. Consultado 1 set. 2021. Disponible en http://repositorio.iica.int/bitstream/11324/2654/1/BVE17038732e.pdf4.

IBC (Instituto del Bien Común, Perú). 2016. Tierras comunales: más que preservar el pasado es asegurar el futuro. El estado de las comunidades indígenas en el Perú (en línea). Lima, Perú. Consultado 5 set. 2021. Disponible en http://www.ibcperu.org/wp-content/ uploads/2016/05/Informe-2016-TIERRAS-COMUNALES lg.pdf.

INEI (Instituto Nacional de Estadística e Informática, Perú). 2012. Resultados definitivos: IV Censo Nacional Agropecuario 2012 (en línea). Lima, Perú. Consultado 17 ago. 2021. Disponible en http://proyectos.inei.gob.pe/web/documentospublicos/resultadosfinalesivcenagro. pdf.

INEI (Instituto Nacional de Estadística e Informática, Perú). 2017. Indicadores económicos y sociales (en línea, sitio web). Consultado 20 abr. 2019. Disponible en https://www.inei.gob. pe/biblioteca-virtual/boletines/indicadores-economicos-y-sociales/1/.

INEI (Instituto Nacional de Estadística e Informática, Perú). 2018. Anuario de estadísticas ambientales: 2018 (en línea). Lima, Perú. Consultado 15 ago. 2021. Disponible en https:// www.inei.gob.pe/media/MenuRecursivo/publicaciones digitales/Est/Lib1637/libro.pdf.

INEI (Instituto Nacional de Estadística e Informática, Perú). 2020a. Compendio estadístico: Perú 2012-2020 (en línea). Lima, Perú. Consultado 16 ago. 2021. Disponible en https://www. inei.gob.pel.

INEI (Instituto Nacional de Estadística e Informática, Perú). 2020b. Perú: anuario de estadísticas ambientales 2020 (en línea). Lima, Perú. Consultado 17 ago. 2021. Disponible en https:// www.inei.gob.pe/media/MenuRecursivo/publicaciones digitales/Est/Lib1760/libro.pdf.

INIA (Instituto Nacional de Innovación Agraria, Perú). 2018. Hacia una agenda de investi- gación forestal colaborativa para el país. Lima, Perú.

INIA (Instituto Nacional de Innovación Agraria, Perú). 2020. Ecología, silvicultura y productividad de Dypterix ferrea (Ducke) Ducke (en línea). Lima, Perú. Consultado 20 set. 2021. Disponible en https://www.researchgate.net/ publication/338920688 Ecologia silvicultura y productividad de Dipteryx ferrea $\mathrm{Du}$ cke Ducke.

Ipsos. 2020. Encuesta nacional urbana - rural (en línea, diapositivas). Lima, Perú. 12 diapositivas, color. Consultado 16 ago. 2021. Disponible en https://www.ipsos.com/sites/default/ files/ct/news/documents/2020-10/problemas del pais octubre 2020 - encuesta de opinion el comercio-ipsos.pdf.

ITTO (International Tropical Timber Organization, Japón). 2016. Criteria and indicators for the sustainable management of tropical forests (en línea). Yokohama, Japón. 82 p. (Policy Development, $n .^{\circ}$ 21). Consultado 28 jul. 2021. Disponible en https://www.itto.int/direct/topics/topics_pdf_download/topics_id=4872\&$\underline{\text { no }=1 \& \text { disp }=\text { inline. }}$.

Kenny-Jordan, CB; Herz, C; Añazco, M; Andrade, M. 1999. Construyendo cambios: desarrollo forestal comunitario en los Andes. Quito, Ecuador, FAO. 446 p.

Kometter, R. 2016. Estudio de condiciones habilitantes de la opción de mitigación del sector forestal: manejo forestal sostenible en concesiones forestales maderables (en línea). S.l., Helvetas Swiss Intercooperation. 47 p. (Proyecto Planificación Contra el Cambio Climático). Consultado 11 ago. 2020. Disponible en https://www.researchgate.net/ publication/320206341 Condiciones habilitantes de la opcion de mitigacion del sector forestal Manejo Forestal Sostenible en Concesiones Forestales Maderables.

Kometter, R. 2019. Evaluación del modelo de concesiones forestales con fines maderables en el Perú, que compila los análisis: legal, técnico y económico financiero, así como las propuestas normativas para el fortalecimiento del modelo 
(en línea). S.n.t. 86 p. (Proyecto USAID/USFS Forest Oversight and Resource Strengthening Program-Forest). Consultado 11 ago. 2020. Disponible en https://www.researchgate.net/publication/341342819.

Laurance, WF; Goosem, M; Laurance, SGW. 2009. Impact of roads and linear clearing of tropical forests. Trends in Ecology and Evolution 24(12):659-669. DOI: https://doi. org/10.1016/j.tree.2009.06.009.

Ley Forestal y de Fauna Silvestre n. ${ }^{\circ} 29763$. Diario Oficial El Peruano. Perú. 22 jul. 2011.

López, M; Hergoualc'h, K; Angulo, O; Baker, T; Chimner, R; del Águila, J; del Castillo, D; Freitas, L; Fuentealva, B; García, E; Honorio, E; Kazuyo, H; Lilleskov, E; Málaga, N; Maldonado, M; Martín, M; Mori, T; Planas, AM; Roucoux, K; Vacalla, F. 2020. What do we know about Peruvian peatlands? (en línea). Bogor, Indonesia, CIFOR. (Occasional Paper, n. ${ }^{\circ}$ 210). Consultado 29 jul. 2021. Disponible en https://www. cifor.org/publications/pdf files/OccPapers/ OP-210.pdf.

Louman, B; Stolan, D. 2002. Manejo forestal sostenible en América Latina: ¿económicamente viable o una utopía? (en línea). Revista Forestal Centroamericana (39):25-32. Consultado 20 jul. 2021. Disponible en http://201.207.189.89/ bitstream/handle/11554/10451/Manejo-forestal-sostenible.pdf?sequence $=1$ \&isAllowed $=\mathrm{y}$.

Lovejoy, TE; Nobre, C. 2020. Amazon tipping point (en línea). Science Advances 4(2). Consultado 4 set. 2021. Disponible en https://advances.sciencemag.org/content/4/2/eaat2340. full.

Lund, HG. 2009. What is a degraded forest? (en línea). Virginia, Estados Unidos de América, s.e. Consultado10 jul. 2021. Disponible en https ://www.researchgate.net/publication/280921178 What is a degraded forest.

Mahar, DJ. 1989. Government policies and deforestation in Brazil's Amazon region (en línea). Washington DC, Estados Unidos de América, WB. Consultado 20 set. 2021. Disponible en https://documents1.worldbank.org/curated/ en/304691468770373897/pdf/multi-page.pdf.
Makki, S; Kalliola, R; Vuorinen, K. 2001. Road construction in the peruvian Amazon: process, causes and consequences. Environmental Conservation 28(3):199-214.

Malleux, J. 1975. Mapa forestal del Perú: memoria explicativa. Lima, Perú, UNALM. 161 p.

Malleux, J. 2013. Cincuenta años de educación forestal en el Perú y América Latina, sus perspectivas a futuro. Xilema 26(1):10-17.

Malleux, R. 2008. Tenencia de los bosques en el Perú (en línea). Lima, Perú, FAO. Consultado 20 set. 2021. Disponible en https://www. fao.org.forestry/doenload/17195-0fb061577/ bfa399.

Mamani, A; Benavides, J; González, F; Mendoza, R; Calderón, A; Saavedra, L. 2019 Restauración de paisajes en el Perú: sitios prioritarios y evaluación de oportunidades. Lima, Perú, SERFOR. 133 p.

Marengo, J; Nobre, CA; Chou, SC; Tomasella, J; Sampaio, G; Alves, LM; Obregón, GO; Soares, WR; Betts, R; Kay, G. 2011. Riscos das mudanças climáticas no Brasil: análise conjunta Brasil-Reino Unido sobre os impactos das Mudanças Climáticas e do Desmatamento na Amazonia. São Paulo, Brasil, INPE. 56 p.

Marengo, JA; Souza, CM; Thonicke, K; Burton, C; Halladay, K; Betts, R; Alves, L; Soares, W. 2018. Changes in climate and land use over the Amazon region: current and future variability and trends. Frontier in Earth Science 6(228):1-21. DOI: https://doi.org/10.3389/ feart.2018.00228.

Margulis, S. 2003. Causes of deforestation of the brazilian Amazon (en línea). Washington DC, Estados Unidos de América, WB. (Working Paper, . $^{\circ}$ 22). Consultado 8 set. 2021. Disponible en https://documents1.worldbank.org/curated/en/758171468768828889/pdf/277150PAPER0wbwp0no1022.pdf.

Martínez, G; Perera, A; Peterson, U; Iverson, L (eds.). 2018. Ecosystem services from forest landscapes (en línea). Cham, Suiza, Springer. Consultado 8 set. 2021. Disponible en https://www.researchgate.net/publica- 
tion/323947747 Ecosystem Services from Forest Landscapes An Overview.

Matricardi, EA; Skole, T; Costa, OB; Pedlowski, MA; Samek, JH; Miguel, EP. 2020. Long-term forest degradation surpasses deforestation in the Brazilian Amazon (en línea). Science 369(6509):1378-1382. Consultado 10 set. 2021. Disponible en https://science.sciencemag.org/ content/369/6509/1378.full.

Mejía, E; Cano, W; de Jong, W; Pacheco, P; Tapia, S; Morocho, J. 2015. Actores, aprovechamiento de madera y mercados en la Amazonía peruana. Bogor, Indonesia, CIFOR. 91 p. (Documentos Ocasionales, n. ${ }^{\circ}$ 145).

Menton, M; Cronkleton, P. 2019. Migration and forests in the peruvian Amazon: a review (en línea). Bogor, Indonesia, CIFOR. (Working Paper, n. ${ }^{\circ}$ 251). Consultado 25 ago. 2021. Disponible en https://www.cifor.org/publications/ pdf files/WPapers/WP251Menton.pdf.

Meyer, CA. 1993. Environmental and natural resource accounting: where to begin?. Washington DC, Estados Unidos de América, WRI. 20 p.

Meza, A; Cornelius, JP. (eds.). 2006. La agroforestería en Perú, con énfasis en la Amazonía: una bibliografía anotada (en línea). Nairobi, Kenia, ICRAF. Consultado 21 ago. 2021. Disponible en https://es.scribd.com/doc/167080363/ICRAF2006-La-Agroforesteria-en-Peru-con-enfasisen-la-Amazonia.

Miller, KR. 1980. Planificación de parques nacionales para el ecodesarrollo de América Latina. Madrid, España, FEDMA. 500p.

MINAGRI (Ministerio de Agricultura, Perú). 2002. Estrategia nacional forestal: versión concertada con instituciones y actores forestales (en línea). Lima, Perú. Consultado 6 set. 2021. Disponible en https://www.minagri.gob. pe/portal/download/pdf/especiales/leyforestalydefaunasilvestre/documentosdeconsulta/ estrategianacionaforesta-enf.pdf.

MINAGRI (Ministerio de Agricultura, Perú). 2005. Plan nacional de reforestación (en línea). Lima, Perú. Consultado 26 ago. 2021. Dis- ponible en https://www.minagri.gob.pe/portal/ download/pdf/especiales/leyforestalydefaunasilvestre/documentosdeconsulta/plannacionaldereforestacion.pdf.

MINAGRI (Ministerio de Agricultura, Perú). 2008. Plan estratégico sectorial multianual de agricultura 2007-2011 (en línea). Lima, Perú. Consultado 26 ago. 2021. Disponible en http:// repositorio.minagri.gob.pe/xmlui/handle/MINAGRI/733.

MINAGRI (Ministerio de Agricultura, Perú). 200a. Bambú: biología, cultivo, manejo y usos en el Perú. Lima, Perú. 68 p.

MINAGRI (Ministerio de Agricultura, Perú). 2010b. Marco conceptual general de la lucha contra la corrupción en el Perú: propuesta preliminar para revisión y aportes (en línea). Lima, Perú. Consultado 27 ago. 2021. Disponible en https://www2.congreso.gob.pe/ sicr/cendocbib/con4_uibd.nsf/D97570437CACAA5805257B810050ED0C/\$FILE/MARCOCONCEPTUALPRELIMINAR.pdf.

MINAGRI (Ministerio de Agricultura y Riego, Perú). 2015. Estrategia nacional de agricultura familiar 2015-2021 (en línea). Lima, Perú. Consultado 27 ago. 2021. Disponible en https://www.midagri.gob.pe/ portal/planes-y-estrategias/planes-estrattegias-2015/13470-estrategia-nacional-de-agricultura-familiar-2015-2021-aprobado-con-decreto-supremo-n-009-2015-minagri.

MINAGRI (Ministerio de Agricultura y Riego, Perú). 2016a. Plan nacional de desarrollo sostenible de la palma aceitera en el Perú 2016-2025 (en línea). Lima, Perú. Consultado 27 ago. 2021. Disponible en https://www.midagri.gob.pe/portal/download/pdf/p-agraria/ pnds 2016-2025 propuesta.pdf.

MINAGRI (Ministerio de Agricultura y Riego, Perú). 2016b. Estudio del cacao en el Perú y en el mundo (en línea). Lima, Perú. Consultado 22 ago. 2021. Disponible en https://br. search.yahoo.com $/$ search $? \mathrm{fr}=$ mcafee\&type $=\mathrm{E}-$ 210BR714G0\&p=Minagri.+2016.+Estudio+de $\underline{\mathrm{l}+\mathrm{cacao}+\mathrm{en}+\mathrm{el}+\mathrm{Per} \% \mathrm{C} 3 \% \mathrm{BA}+\mathrm{y}+\mathrm{en}+\mathrm{el}+\text { mun- }}$ do+Lima. 
MINAGRI (Ministerio de Agricultura y Riego, Perú). 2017a. Política Nacional Forestal y de Fauna Silvestre (en línea). Lima, Perú. Consultado 26 ago. 2021. Disponible en https://www. minagri.gob.pe/portal/download/pdf/especiales/politica-nacional.pdf.

MINAGRI (Ministerio de Agricultura y Riego, Perú). 2017b. Informe del arroz (en línea). Lima, Perú. Consultado 26 ago. 2021. Disponible en https://www.minagri.gob.pe/portal/ boletin-de-arroz/arroz-2017.

MINAGRI (Ministerio de Agricultura y Riego, Perú). 2017c. Plan nacional de desarrollo ganadero 2017 - 2027: Perú, país ganadero (en línea). Lima, Perú. Consultado 23 ago. 2021. Disponible en https://www.midagri.gob.pe/ portal/download/pdf/dg-ganaderia/plan-nacional-ganadero-2017-2027.pdf.

MINAGRI (Ministerio de Agricultura y Riego, Perú). 2017d. Diagnóstico de crianzas priorizadas para el plan ganadero 2017. Lima, Perú.

MINAGRI (Ministerio de Agricultura y Riego, Perú). 2018. Análisis de la cadena productiva del cacao (en línea). Lima, Perú. Consultado 24 ago. 2021. Disponible en http://repositorio. minagri.gob.pe/xmlui/handle/MIDAGRI/66?$\underline{\text { show }=\text { full\&locale-attribute }=\text { es }}$.

MINAGRI (Ministerio de Agricultura y Riego, Perú). 2019. Plan nacional de cultivos: campaña agrícola 2019-2020 (en línea). Lima, Perú. Consultado 25 ago. 2021. Disponible en https://cdn. www.gob.pe/uploads/document/file/471867/ Plan Nacional de Cultivos 2019 2020b.pdf.

MINAGRI (Ministerio de Agricultura y Riego, Perú). 2020. Plan nacional de promoción de plantaciones forestales comerciales 2020-2050 (en línea). Lima, Perú. Consultado 28 ago. 2021. Disponible en https://www.minagri.gob. $\mathrm{pe} / \mathrm{portal} /$ download/pdf/especiales/leyforestalydefaunasilvestre/documentosdeconsulta/ plannacionaldereforestacion.pdf.

MINAM (Ministerio del Ambiente, Perú). 2010. El Perú y el cambio climático: segunda comunicación nacional del Perú a la Convención Marco de Naciones Unidas sobre Cambio Climático. Lima, Perú, Aguilar.
MINAM (Ministerio del Ambiente, Perú). 2011. La desertificación en el Perú: cuarta comunicación nacional a la Convención de Lucha Contra la Desertificación y Sequía (en línea). Lima Perú. Consultado 23 ago. 2021. Disponible en https://es.scribd.com/document/73752583/La-Desertificacion-en-el-Peru.

MINAM (Ministerio del Ambiente, Perú). 2015. Mapa nacional de cobertura vegetal: memoria descriptiva (en línea). Lima, Perú. Consultado 23 ago. 2021. Disponible en https:// www..gob.pe/patrimonio-natural/wp-content/ uploads/sites/6/2013/10/MAPA-NACIONAL-DE-COBERTURA-VEGETAL-FINAL. compressed.pdf.

MINAM (Ministerio del Ambiente, Perú). 2016a. Áreas Naturales Protegidas del Perú (2011-2015): conservación para el desarrollo sostenible (en línea). Lima, Perú. Consultado 24 ago. 2021. Disponible en https://www. SERNANP.gob.pe/documents/10181/11956/ Informe-4-Areas-Naturales-Protegidas.pdf/4f8d0a04-2e65-419e-9c07-e1578241a726.

MINAM (Ministerio del Ambiente, Perú). 2016b. Estrategia nacional de lucha contra la desertificación y la sequía 2016-2030 (en línea). Lima, Perú. Consultado 19 ago. 2021. Disponible en https://sinia..gob.pe/documentos/estrategia-nacional-lucha-contra-desertificacion-sequia-2016-2030.

MINAM (Ministerio del Ambiente, Perú). 2016c. El Perú y el cambio climático: tercera comunicación nacional del Perú a la Convención Marco de las Naciones Unidas sobre el Cambio Climático (en línea). Lima, Perú. Consultado 18 ago. 2021. Disponible en https://www..gob. pe/wp-content/uploads/2016/05/Tercera-Comunicaci\%C3\%B3n.pdf.

MINAM (Ministerio del Ambiente, Perú). 2018. Listado de especies de flora silvestre CITES - Perú (en línea). Lima, Perú. Consultado 25 ago. 2021. Disponible en https://www..gob. pe/simposio-peruano-de-especies-cites/wp-content/uploads/sites/157/2018/08/Listado-FLORA-CITES-FINAL.pdf. 
MINAM (Ministerio del Ambiente, Perú). 2019. Sistema de lomas costeras (en línea). Lima, Perú. Consultado 17 ago. 2021. Disponible en https://patrimoniomundial.cultura. $\mathrm{pe} /$ sites/default/files/li/pdf/17.\%20Sistema\%20 de\%20Lomas\%20-\%20Esp.pdf.

MINAM (Ministerio del Ambiente, Perú); PNCBMCC (Programa Nacional de Conservación de Bosques para la Mitigación del Cambio Climático, Perú). 2021a. Línea de base de los bosques secos de la costa norte del Perú al 2018 (en línea). Lima, Perú. (Apuntes del Bosque, n. ${ }^{\circ}$ 4). Consultado 28 ago. 2021. Disponible en http://www.bosques.gob.pe/archivo/Apuntes-del-bosque-4.pdf.

MINAM (Ministerio del Ambiente, Perú); PNCBMCC (Programa Nacional de Conservación de Bosques para la Mitigación del Cambio Climático, Perú). 2021b. Bosque y pérdida de bosque (en línea). Lima, Perú. Consultado 20 set. 2021. Disponible en http://geobosques.minam.gob.pe/geobosque/view/perdida.php.

Mongabay. 2020. Peruvian court absolves cacao company of illegal Amazon deforestation after "lobbying effort" (en línea). Mongabay, s.l.; 18 dic. Consultado 15 set. 2021. Disponible en https://news.mongabay.com/2020/12/peruvian-court-absolves-cacao-company-of-illegal-amazon-deforestation/.

Moore, T. 1992. Nueva legislación forestal: ¿manejo de bosques o de capitales? Debate Agrario (15):15-35.

Morales, C. 2012. Los costos de la inacción ante la desertificación y la degradación de las tierras en escenarios alternativos de cambio climático (en línea). Santiago, Chile, CEPAL. Consultado 8 set. 2021. Disponible en https://www.cepal. org/es/publicaciones/4009-costos-la-inaccion-la-desertificacion-degradacion-tierras-escenarios-alternativos.

Morcatty, TQ; Bausch, JG; Anne-Isola, K; Ni, Q; Durigan, C; Svensson, M; Nijman, V. 2020. Illegal trade in wild cats and its link to Chinese-led development in Central and South America. Conservation Biology (34)6:1525-1535. DOI: https://doi.org/10.1111/cobi.13498.
Mosquera, GM; Marín, F; Stern, M; Bonnesoeur, V; Ochoa-Tocachi, F; Dañobeytia, F; Crespo, P. 2021.Progress in understanding the hydrology of high-elevation Andean grasslands under changing land use. Science of The Total Environment 80:1-14. DOI: https://doi. org/10.1016/j.scitotenv.2021.150112.

Muñoz, F. 2014. Presente y futuro del sector forestal peruano: el caso de las concesiones y las plantaciones forestales (en línea). Lima, Perú, MINAGRI. Consultado 3 set. 2021. Disponible en https://www.bcrp.gob.pe/docs/Publicaciones/Seminarios/2014/forestal/forestal-2014-munoz.pdf.

Muñoz, I. 2016. Agroexportación y sobreexplotación del acuífero de Ica en Perú (en línea). Anthropologica 34(37):115-138. Consultado 3 set. 2021. Disponible en http://www.scielo.org. pe/pdf/anthro/v34n37/a06v34n37.pdf.

Naim, M. 1994. Las instituciones: el eslabón perdido en las reformas económicas de América Latina. Seminario Latinoamericano sobre Crecimiento Económico (1, 1994, Santafé de Bogotá, Colombia). Santafé de Bogotá, Colombia.

Navarro, R. 2014. Avances tecnológicos hacia la trazabilidad de la madera (en línea). Lima, Perú, OSINFOR. Consultado 5 set. 2021. Disponible en https://www.OSINFOR.gob.pe/portal/data/ documentos/trazabilidad OSINFOR.pdf.

Nepstad, D; Carvalho, G; Barros, AC; Alencar, A; Capobianco, JP; Bishop, J; Prins, E. 2001. Road paving, fire rgime feedbacks, and the future of Amazon forests. Forest Ecology and Management (154):395-407. DOI: https://doi. org/10.1016/S0378-1127(01)00511-4.

Nkonya, E; Mirzabaev, A; von Braun, J (eds.). 2016. Economics of land degradation and improvement: an introduction and overview. In Economics of land degradation and improvement: a global assessment for sustainable development. Cham, Suiza, Springer.

Oliveira, PJC; Asner, GP; Knapp, DE; Almeyda, A; Galvan-Gildemeister, R; Keene, S; Raybin, RF; Smith, RC. 2007. Land-use allocation protects the peruvian Amazon. Science 317(5842): 
1233-1236. DOI: https://doi.org/10.1126/science.1146324.

ONERN (Oficina Nacional de Evaluación de Recursos Naturales, Perú). 1982. Clasificación de tierras por Capacidad de Uso Mayor: cuarta aproximación. Lima, Perú.

ONERN (Oficina Nacional de Evaluación de Recursos Naturales, Perú). 1985. Los recursos naturales del Perú. Lima, Perú. 326 p.

OSINFOR (Organismo de Supervisión de los Recursos Forestales y de Fauna Silvestre, Perú). 2017. Anuario Estadístico 2016 (en línea). Consultado 20 ago. 2021. Disponible en https:// www.osinfor.gob.pe/publicaciones/anuario-estadistico-2016/.

OSINFOR (Organismo de Supervisión de los Recursos Forestales y de Fauna Silvestre, Perú). 2019. OSINFOR en cifras: reporte estadístico IV trimestre-2019 (en línea). Lima, Perú. Consultado 27 ago. 2021. Disponible en https://cdn.www.gob.pe/uploads/document/file/1016204/OSINFOR-EN-CIFRAS-2019-2206202020200716-31706-1ogblh.pdf.

Painter, J. 2008. Perú quiere "deforestación cero" (en línea). BBC Mundo, Londres, Reino Unido; 5 dic. Consultado 12 jul. 2021. Disponible en http://news.bbc.co.uk/hi/spanish/science/ newsid 7767000/7767872.stm.

Parry, L; Barlow, J; Pereira, H. 2014. Wildlife harvest and consumption in Amazonia's urbanized wilderness. Conservation Letters 7(6):565-574. DOI: https://doi.org/10.1111/ conl.12151.

Pautrat, L. (ed.). 2020. Propuestas para la gestión sostenible de bosques en la Amazonía peruana (en línea). Lima, Perú, IDL. Consultado 14 jul. 2021. Disponible en https://www.idl.org. pe/portfolio/13698-2/.

Pautrat, L; Lucich, I. 2006. Análisis preliminar sobre gobernabilidad y cumplimiento de la legislación del sector forestal en el Perú (en línea). Washington DC, Estados Unidos de América, World Bank Group. Consultado 20 abr. 2019. Disponible en http://www.keneamazon.net/Documents/Publications/Virtual-Library/Marco-Normativo/66.pdf.
Pautrat, L; Torres, P; Samaniego, C. 2010. Sobre la institucionalidad forestal en el Perú (en línea). Lima, Perú, Sociedad Peruana de Ecodesarrollo. Consultado 28 jul. 2021. Disponible en https://www.midagri.gob.pe/portal/download/ pdf/especiales/leyforestalydefaunasilvestre/ aporte-lffs-institucionalidad-sectorforestal-pautrat27feb10.pdf.

Peres, CA; Barlow, J; Laurance, WF. 2006. Detecting anthropogenic disturbance in tropical forests. Trends in Ecology and Evolution 21(5):227-229.DOI: http://dx.doi. org/10.1016/j.tree.2006.03.007.

Peres, CA; Palacios, E. 2007. Basin-wide effects of game harvest on vertebrate population densities in Amazonian forests: implications for animal-mediated seed dispersal. Biotropica 39(3):304- 315. DOI: https://doi.org/10.1111/j. 1744-7429.2007.00272.x.

Pierret, PV; Dourojeanni, MJ. 1966. La caza y la alimentación humana en las riberas del río Pachitea, Perú. Turrialba 16(3):271-277.

Pierret, PV; Dourojeanni, MJ. 1967. Importancia de la caza para alimentación humana en el curso inferior del río Ucayali, Perú. Revista Forestal del Perú 1(2):10-21. DOI: http://dx.doi. org/10.21704/rfp.v1i2.834.

Pizarro, R. 2021. Sistemas de instrumentos de fijación de precios del carbono en América Latina y jurisdicciones de las Américas relevantes. Santiago, Chile, CEPAL. (Documentos de Proyectos, $n .^{\circ} 87$ ).

Portillo-Quintero, CA; Sánchez-Azofeifa, GA. 2010. Extent and conservation of tropical dry forests in the Americas. Biological Conservation 143(1):144-155. DOI: https://doi.org/10.1016/j.biocon.2009.09.020.

Portuguez, H; Huerta, P. 2005. Mapa de deforestación de la Amazonía peruana 2000: memoria descriptiva. Lima, Perú, INRENA. 74 p.

Prado, E. 2020. Perú responde a informe de EEUU sobre cultivo de coca y producción de cocaína en el país (en línea). La República, Lima, Perú; 31 jul. Consultado 30 jul. 2021. Disponible en https://larepublica.pe/politica/2020/07/31/peru-responde-a-informe-de- 
-eeuu-sobre-cultivo-de-coca-y-produccion-de-cocaina-en-el-pais/.

Prado,JA.2019. Plantaciones forestales: más allá de los árboles (en línea). Santiago, Chile, CORMA. Consultado 13 set. 2021. Disponible en https://cifag.cl/wp-content/uploads/2019/04/ Libro-plantaciones.pdf.

Proética. 2019. Bosques y lucha contra la corrupción: balance de implementación de proyectos REDD+, deforestación en bosques amazónicos y lucha contra la corrupción en el sector forestal 2015-2018 (en línea). Lima, Perú. Consultado 29 jul. 2021. Disponible en https://www.proetica.org.pe/wp-content/ uploads/2019/06/Bosques-y-lucha-contra-la-corrupcion.final .pdf.

Proyecto de Ley 2550/2017. Proyecto de Ley de Incentivos para las Plantaciones Forestales (en línea). Perú. 14 mar. 2018. Consultado 13 ago. 2021. Disponible en https://www. Proy Ley Incentivo Plantaciones Forestales 2017 (1). pdf.

Proyecto de Ley 07501/2021. Proyecto de Ley para Financiamiento de la protección de los Bosques, la Reforestación Nacional y la Recuperación Económica (en línea). Perú. 13 abr. 2021. Consultado 13 ago. 2021. Disponible en https://leyes.congreso.gob.pe/Documentos/2016 2021/Proyectos de Ley y de $\mathrm{Re}-$ soluciones Legislativas/PL07501-20210413. pdf.

Putz, FH; Redford, KH. 2010. The importance of defining 'forest': tropical forest degradation, deforestation, long-term phase shifts, and further transitions. Biotropica 42(1):1020. DOI: https://doi.org/10.1111/j.17447429.2009.00567.x.

Putzel, LC; Padoch, C; Pinedo-Vasquez, M. 2008. The chinese timber trade and the logging of peruvian Amazonia. Conservation Biology 22(6):1659-61. DOI: https://doi.org/10.1111/ j.1523-1739.2008.01065.x.

Putzel, L; Padoch, C; Ricse, A. 2012. Putting back the trees: smallholder silvicultural enrichment of post-logged concession forest in peruvian Amazonia. Small-scale Forestry
12(3):421-436. DOI: https://doi.org/10.1007/ s11842-012-9221-3.

Putzel, L; Peters, CM; Romo, M. 2010. Post-logging regeneration and recruitment of shihuahuaco (Dipteryx spp.) in peruvian Amazonia: implications for management. Forest Ecology and Management 261(2011):1099-1105. DOI: https://doi.org/10.1016/j.foreco.2010.12.036.

Qin, Y; Xiao, X; Wigneron, JP; Ciais, P; Brandt, M; Fan, L; Li, X; Crowell, S; Wu, X; Doughty, R; Zhang, Y; Liu, F; Sitch, S; Moore, B. 2021. Carbon loss from forest degradation exceeds that from deforestation in the brazilian Amazon. Nature Climate Change (11):442-448. DOI: https://doi.org/10.1038/s41558-021-01026-5.

Ráez, E (ed.). 2016. Ambiente y recursos naturales del Perú: quinquenio 2011-2016 (en línea). Lima, Perú, DAR. Consultado 2 set. 2021. Disponible en https://www.researchgate.net/publication/323664614 Ambiente y Recursos Naturales_del_Peru_Quinquenio_2011-2016.

Ramírez, R; Ramos, J. 2021. Propuesta de un plan de desarrollo del sector forestal

Peruano. Anales Científicos 82(1):63-72. DOI: https://doi.org/10.21704/ac.v82i1.1742.

Ramos, C; Peters, BG. 2021. Conclusion: the present and future of public administration in Latin America. In Peters, BG; Tercedor, CA; Ramos, C (eds.). The Emerald handbook of public administration in Latin America. Bingley, Reino Unido, Emerald. p. 475-488. DOI: https:// doi.org/10.1108/978-1-83982-676-420201023.

Rodríguez, LCE; Pasalodos-Tato, M; DíazBalteiro, L; McTague, JP. 2014. The importance of industrial forest plantations. In Borges, J; Diaz-Balteiro, L; McDil, M; Rodríguez, L. The management of industrial forest plantations. Dordrecht, Países Bajos. p. 3-26. DOI: https:// doi.org/10.1007/978-94-017-8899-1 1.

Rodríguez, LO; Young, KR. 2000. Biological diversity of Peru: determining priority areas for conservation. Ambio 29(6):329-337. DOI: https://doi.org/10.1579/0044-7447-29.6.329.

Román, F; Mamani, A; Cruz, A; Sandoval, C; Cuesta, F. 2018. Orientaciones para la restaura- 
ción de ecosistemas forestales y otros ecosistemas de vegetación silvestre. Lima, Perú, OSINFOR. 105 p.

Rosales, S. 2019. Tala ilegal: una polémica sobre cómo detectar origen ilícito de madera (en línea). Gestión, Lima. Perú; 1 abr. Consultado 11 ago. 2020. Disponible en https:// gestion.pe/economia/tala-ilegal-polemica-norma-abre-discusion-detectar-origen-ilicito-madera-262872-noticial.

Sabogal, C. 2018. Restauración con enfoque de paisaje en el contexto de Perú. In Simposio Nacional en Restauración de Ecosistemas Forestales con enfoque de paisajes - Experiencias y desafíos hacia el desarrollo sostenible $(1,2018$, Lima, Perú). Memoria del Simposio. Lima, Perú. s.p.

Sabogal, C. (ed.). 2019. Diagnóstico situacional de la formación académica y la investigación en el sector forestal y de fauna silvestre, con enfoque en la Amazonia peruana. Lima, Perú, USAID. 93 p.

Sabogal, C; Colán, V; Galván, O; Current, D; Domínguez, G; Yepes, F. 2002. Aspectos metodológicos para determinar opciones de manejo de bosques secundarios (purmas) en la Amazonía peruana, con especial referencia a la zona de Pucallpa. Revista Forestal del Perú 24(1-2):85-108.

Sabogal, C; Nalvarte, J; Colán, V. 2008. Análisis del marco legal para el manejo forestal por pequeños productores en la Amazonia peruana (en línea). Lima, Perú, CIFOR. 159 p. Consultado 11 ago. 2020. Disponible en https://www. cifor.org/knowledge/publication/2757/.

Salazar, M; Rivadeneyra, D. 2016. Amazonía arrasada: el grupo Melka y la deforestación por palma aceitera y cacao en el Perú (en línea). Lima, Perú, Oxfam. Consultado 21 set. 2021. Disponible en https://keneamazon.net/Documents/Publications/Amazonia-Arrasada.pdf.

Salo, M; Helle, S; Toivonen, T. 2011. Allocating logging rights in peruvian Amazonia-does it matter to be local?. PLoS ONE 6(5):e19704. DOI: $\quad$ https://doi.org/10.1371/journal. pone.0019704.
Salo, M; Toivonen, T. 2009. Tropical timber rush in peruvian Amazonia: spatial allocation of forest concessions in an uninventoried frontier. Environmental Management 44(4):609-623. DOI: https://doi.org/10.1007/ s00267-009-9343-3.https://link.springer.com/ article/10.1007/s00267-009-9343-3.

Sanchez, PA. 1976. Properties and management of soils in the Tropics. New York, Estados Unidos de América, Wiley. 618 p.

Sanchez, PA. 1979. Soil fertility and conservation considerations for agroforestry systems in the humid tropics of Latin America. In Mongi, HO; Huxley, PA (eds.). Soil research in agroforestry. Nairobi, Kenya, ICRAF. p. 79-124.

Sanchez, PA; Bandy, DE; Villachica, JH; Nicholaides, JJ. 1982. Amazon basin soils: management for continuous crop production. Science 216(4548):821-827.

SERFOR (Servicio Nacional Forestal y de Fauna Silvestre, Perú). 2018. Anuario Forestal y de Fauna Silvestre 2016 (en línea). Lima, Perú, MINAGRI. Consultado 20 set. 2021. Disponible en https://www.gob.pe/institucion/SERFOR/ informes-publicaciones/1124181-anuario-forestal-y-fauna-silvestre-2018.

SERFOR (Servicio Nacional Forestal y de Fauna Silvestre, Perú). 2019. Anuario Forestal y de Fauna Silvestre 2018 (en línea). Lima, Perú, MINAGRI. Consultado 22 set. 2021. Disponible en http://repositorio.serfor.gob.pe/handle/ SERFOR/893.

SERFOR (Servicio Nacional Forestal y de Fauna Silvestre, Perú). 2020. Plan Nacional de Investigación Forestal y de Fauna Silvestre (en línea). Lima, Perú. Consultado 4 ago. 2021. Disponible en https://www.gob.pe/institucion/ SERFOR/noticias/311804-minagri-aprobo-el-plan-nacional-de-investigacion-forestal-y-de-fauna-silvestre.

SERFOR (Servicio Nacional Forestal y de Fauna Silvestre, Perú) / GIZ (Sociedad Alemana de Cooperación Internacional). 2016. Estudio de la oferta educativa y demanda laboral en el sector forestal a nivel nacional. Lima, Perú. 180 p. 
SERNANP (Servicio Nacional de Áreas Naturales Protegidas por el Estado, Perú). 2019. Sistema de lomas costeras: formulario de presentación (en línea). Lima, Perú. Consultado 9 ago. 2021. Disponible en https://patrimoniomundial.cultura.pe/sites/default/files/li/pdf/17.\%20 Sistema\%20de\%20Lomas\%20-\%20Esp.pdf.

SERNANP (Servicio Nacional de Áreas Naturales Protegidas por el Estado, Perú). 2021. Sistema de áreas naturales protegidas del Perú (en línea). Consultado 4 set. 2021. Disponible en https://www.SERNANP.gob.pe/documents/10181/2872611/Listado ANP 28-08-2020/ ddc00c79-df75-4d22-bada-5cda642a5b3f.

Shirley, HL. 1968. Educación forestal en el Perú. Revista forestal del Perú 2(1):7-8. DOI: http:// dx.doi.org/10.21704/rfp.v2i1.1074.

Sierra, Y. 2018. Perú: comunidades con multas millonarias por regentes forestales que no cumplieron la ley (en línea). Mongabay, s.l.; 29 nov. Consultado19 ago. 2021. Disponible en https://es.mongabay.com/2018/11/peru-comunidades-con-multas-millonarias-por-regentes-forestales-que-no-cumplieron-la-ley/.

Sierra, Y. 2019a. Madre de Dios: seven Brazil nut concessions investigated for illegal timber extraction (en línea). Mongabay Series: Global Forests, s.l.; 23 feb. 2019. Consultado 20 abr. 2019. Disponible en https://news.mongabay. com $/ 2019 / 02 / \mathrm{madre}$-de-dios-seven-brazil-nut-concessions-investigated-for-illegal-timber-extraction/.

Sierra, Y. 2019b. Peru: report reveals high rates of illegality in timber extraction (en línea). Mongabay Series: Global Forests, s.l.; 14 feb. 2019. Consultado 23 abr. 2019. Disponible en https://news.mongabay. com $/ 2019 / 02 /$ peru-report-reveals-high-rates-of-illegality-in-timber-extraction/?n3wsletter\&utm_source $=$ Mongabay + Newslet ter\&utm campaign $=\mathrm{f} 42 \mathrm{f} 6 \mathrm{cfcab}-$ newsletter 201902 21\&utm medium=email\&utm term $=0 \quad 940652 \mathrm{e} 1 \mathrm{f} 4-\mathrm{f} 42 \mathrm{f} 6 \mathrm{cfcab}-67233711$.

Sierra, Y. 2020. Perú: detienen a 17 personas involucradas en red de lavado de madera conocida como "Los hostiles de la Amazonía" (en línea). Mongabay, s.l.; 26 ago. Consultado 18 ago. 2021. Disponible en https://es.mongabay.com $/ 2020 / 08 /$ peru-funcionarios-lavado-madera-hostiles-amazonia/.

Sinovas, P; Price, B; King, E; Pavitt, A. 2017. Wildlife trade in Amazon countries: an analysis of trade in CITES-listed species. Cambridge, Reino Unido, UN Environment. 104 p.

Sist, P. 2 set. 2021. Couper moins et laisser reposer: une nouvelle gestion des forêts tropicales s'impose (en línea). The Convesation, s.l. Consultado 10 set. 2021. Disponible en https:// theconversation.com/couper-moins-et-laisserreposer-une-nouvelle-gestion-des-forets-tropicales-simpose-164637.

Smith, J; Colan, V; Sabogal, C; Snook, LK. 2006. Why policy reforms fail to improve logging practices: the role of governance and norms in Peru. Forest Policy and Economics 8(4):458469.

Smith, J; Finegan, B; Sabogal, C; Ferreira, M; Siles, G; van de Kop, P; Díaz, A. 2002. Bosques secundarios y manejo integrado de recursos en la agricultura migratoria por colonos en Latinoamérica. Turrialba, Costa Rica, CATIE. 33 p. (Serie Técnica, n. ${ }^{\circ} 332$ ).

Smith, J; Finegan, B; Sabogal, C; Ferreira, M; Siles, G; van de Kop, P; Díaz, A. 2005. Manejo da floresta secundária em agricultura migratória no Peru, Brasil e Nicarágua (en línea). Belém, Brasil, Embrapa. (Documentos, n. ${ }^{\circ} 213$ ). Consultado 25 set 2021. Disponible en https:// ainfo.cnptia.embrapa.br/digital/bitstream/ item/145249/1/DOC-213.pdf.

Smith, J; Sabogal, C; de Jong, W; Kaimowitz, D. 1997. Bosques secundarios como recurso para el desarrollo rural y la conservación ambiental en los trópicos de América Latina. Bogor, Indonesia, CIFOR. (Occasional Paper, n. ${ }^{\circ} 13$ ).

Solís, D. 2016. Impacto de la supervisión de las concesiones forestales maderables en el cumplimiento de la Ley Forestal en el Perú (en línea). Consorcio de Investigación Economía y Social (89):49-60. Consultado 11 ago. 2020. Disponible en http://www.cies.org.pe/sites/default/files/files/articulos/economiaysociedad/ 
impacto de la supervision de las concesiones forestales maderables en el cumplimiento de la ley forestal en el peru $\mathrm{d}$. solis.pdf.

Souza, C; Roberts, D. 2005. Mapping forest degradation in the Amazon region with Ikonos images (en línea). International Journal of Remote Sensing 26(3):425-429. Consultado 22 set. 2021. Disponible en https://imazon. org.br/publicacoes/mapping-forest-degradation-in-the-amazon-region-with-ikonos-images/.

SPDA (Sociedad Peruana de Derecho Ambiental, Perú). 2019. Entrevista: Ex-jefe del Servicio Forestal de EE. UU. Analiza el sector peruano (en línea). SPDA Actualidad Ambiental, Lima, Perú; 26 abr. Consultado 11 ago. 2020. Disponible en https://www.actualidadambiental.pe/ entrevista-exjefe-del-servicio-forestal-de-ee-uu=-analiza-sector-forestal-peruano/?fbclidIwAR0tjJLRwYxI7JJRZ4hbpBpiIyNZErKRLlyia0Gktd2YFYkdPNMTAA6yD0c.

Strassburg, BBN; Latawiec, AE; Barioni, LG; Nobre, CA; da Silva, VP; Valentim, JF; Vianna, M; Assad, ED. 2014. When enough should be enough: improving the use of current agricultural lands could meet production demands and spare natural habitats in Brazil. Global Environmental Change 2:84-97. DOI: https://doi. org/10.1016/j.gloenvcha.2014.06.001.

Suárez, G. 2012. Elementos para la política forestal en el Perú (diapositivas, en línea). Lima, Perú, s.e. 45 diapositivas, color. Consultado 20 abr. 2019. Disponible en http://infobosques. com/portal/wp-content/uploads/2016/03/elementos para la politica forestal en el peru. pdf.

Suárez, G. 2021. Situación, tendencias y causas de la deforestación en la Amazonía peruana (en línea). In El futuro de los bosques: del discurso a la acción. Lima, Perú, Congreso de la República. p. 24-35. Consultado 3 oct. 2021. Disponible en http://www.bosquesandinos.org/el-futuro-de-los-bosques-del-discurso-a-la-accion/.

SUNEDU (Superintendencia Nacional de Educación Superior Universitaria, Perú). 2019. Lis- ta de carreras autorizadas: ingeniería (en línea). Lima, Perú. Consultado 20 set. 2021. Disponible en https://www.sunedu.gob.pe/lista-carreras-autorizadas/ingenieria/.

Sylvester, SP; Heitkamp, F; Sylvester, MDPV; Jungkunst, HF; Sipman, HJM; Toivonen, JM; Gonzales, CA; Ospina, JC; Kessler, M. 2017. Relict high-Andean ecosystems challenge our concepts of naturalness and human impact. Scientific Reports 7(3334):1-13. DOI: https:// doi.org/10.1038/s41598-017-03500-7.

Tosi, J. 1960. Zonas de vida natural en el Perú: memoria explicativa sobre el mapa ecológico del Perú. Lima, Perú, OEA. 270 p. (Boletín técnico, $n .^{\circ} 5$ ).

Tuss de Orbegoso, MM. 2017. Concesiones forestales en el Perú: avances y limitaciones (en línea). Tesis Ing. Lima, Perú, UNALM. 61 p. Consultado 11 ago. 2020. Disponible en http://repositorio.lamolina.edu.pe/handle/ UNALM/3524.

Ugarte-Guerra, J; Román-Dañobeytia, F. 2020. Tasas de crecimiento de cuatro especies nativas en plantaciones forestales comerciales en cuatro regiones de la Amazonía peruana. Revista Forestal del Perú 35(3):44-55. DOI: http://dx. doi.org/10.21704/rfp.v35i3.1600.

Urrunaga, JM; Johnson, A; Orbegozo, ID; Mulligan, F. 2020. La máquina lavadora: cómo el fraude y la corrupción en el sistema de concesiones están destruyendo el futuro de los bosques de Perú (en línea). s.l., Environmental Investigation Agency. 72 p. Consultado 11 ago. 2020. Disponible en https://content.eia-global. org/assets/2012/04/La Maquina Lavadora. pdf.

Valcuende, JM; Mutragh, C; Rummenhoeller, K. 2012. Turismo y poblaciones indígenas: espacios, tiempos y recursos (en línea). Revista Electrónica de Geografía y Ciencias Sociales 16(410):741-798. Consultado 20 set. 2021. Disponible en http://www.ub.edu/geocrit/sn/sn410.htm.

Vancutsem, C; Achard, F; Pekel, JF; Vieilledent, G; Carboni, S; Simonetti, D; Gallego, J; Aragão, L; Nasi, R. 2020. Long-term (1990-2019) mon- 
itoring of tropical moist forests dynamics (en línea). De próxima publicación. Consultado 28 ago. 2021. Disponible en https://www.biorxiv. org/content/10.1101/2020.09.17.295774v1.

van der Ven, H; Cashore, B. 2018. Forest certification: the challenge of measuring impacts. Current Opinion in Environmental Sustainability 32:104-111. DOI: https://doi. org/10.1016/j.cosust.2018.06.001.

van Vliet, N; Quiceno-Mesa, MP; Cruz, DR; Neves de Aquino, LJ. 2014.The uncovered volumes of bushmeat commercialized in the Amazonian trifrontier between Colombia, Peru \& Brazil. Ethnobiology and Conservation 3(2014):1-11. DOI: https://doi.org/10.15451/ ec2014-11-3.7-1-11.

Vergara, R. 2019. Sistematización de la información sobre las concesiones forestales con fines maderables. Lima, Perú, s.e. 47 p. Informe final.

Vilela, T; Malky, A; Bruner, A; da Silva, VL; Ribeiro, V; Costa, AA; Escobedo, AJ; Rojas, A; Laina, A; Botero, R. 2020. A better Amazon road network for people and the environment. PNAS 117(13):7095-7102. DOI: https://doi. org/10.1073/pnas.1910853117.

Watters, RF. 1971. Shifting cultivation in Latin America. Roma, Italia, FAO. 305 p.

Weberbauer, A. 1945. El mundo vegetal de los Andes peruanos: estudio fitogeográfico. Lima, Perú, Ministerio de Agricultura. 735 p.

Ye, T; Guo, Y; Chen, G; Yue, X; Xu, R; Coêlho, M; Saldiva, P; Zhao, Q; Li, S. 2021. Risk and burden of hospital admissions associated with wildfire-related PM2.5 in Brazil, 2000-15: a nationwidetime-series study. Lancet Planet Health 5(9):599-607. DOI: https://doi.org/10.1016/ S2542-5196(21)00173-X.

Zamora, C. 1971. Capacidad de uso de los suelos del Perú: tercera aproximación. Lima, Perú, ONERN.

Zegarra E; Gayoso JP. 2015. Cambios en la agricultura y deforestación en la selva peruana: análisis basado en el IV Censo Agropecuario (en línea). In Escobar, J; Fort, R; Zegarra, E (eds.). Agricultura peruana: nuevas miradas desde el censo agropecuario. Lima, Perú, Grade. p. 225-284. Consultado 23 ago. 2021. Disponible en https://www.semanticscholar. org/paper/Cambios-en-la-agricultura-y-deforestaci\%C3\%B3n-en-la-en-Zegarra-Gayoso/ $\underline{18 d 787 a 616357 d 89 b b a 5770 f a d 2 f c 9 a d 824 b a-}$ 9da. 